\title{
FROM EARLY TANG \\ COURT DEBATES TO \\ CHINA'S PEACEFUL RISE
}

\section{Edited by}

Friederike Assandri and Dora Martins 
From Early Tang Court Debates to China's Peaceful Rise 


\title{
icas Publications Series
}

\author{
General Editor \\ Paul van der Velde \\ Publications Officer \\ Martina van den Haak
}

\section{Editorial Board}

Wim Boot (Leiden University); Jennifer Holdaway (Social Science Research Council); Christopher A. Reed (The Ohio State University); Anand A. Yang (Director of the Henry M. Jackson School of International Studies and Chair of International Studies at the University of Washington); Guobin Yang (Barnard College, Columbia University)

The ICAS Publications Series consists of Monographs and Edited Volumes. The Series takes a multidisciplinary approach to issues of interregional and multilateral importance for Asia in a global context. The Series aims to stimulate dialogue amongst scholars and civil society groups at the local, regional and international levels.

The International Convention of Asia Scholars (ICAS) was founded in I997. Its main goals are to transcend the boundaries between disciplines, between nations studied, and between the geographic origins of the Asia scholars involved. ICAS has grown into the largest biennial Asia studies event covering all subjects of Asia studies. So far five editions of ICAS have been held respectively in Leiden (I998), Berlin (200I), Singapore (2003), Shanghai (2005) and Kuala Lumpur (2007). ICAS 6 will be held in Daejeon (South Korea) from 6-9 August 2009.

In 200 I the ICAS secretariat was founded which guarantees the continuity of the ICAS process. In 2004 the ICAS Book Prize (IBP) was established in order to create by way of a global competition both an international focus for publications on Asia while at the same time increasing their visibility worldwide. Also in 2005 the ICAS Publications Series were established.

For more information: www.icassecretariat.org 


\section{From Early Tang Court Debates to China's Peaceful Rise}

Edited by

Friederike Assandri and Dora Martins

AMSTERdaM UNiVERSITY PRESS 
ICAS) Publications Series

Edited Volumes 7

Cover design: JB\&A raster grafisch ontwerp, Westland Layout: The DocWorkers, Almere

ISBN 978905356795 I

e-ISBN 978904850 I 458

NUR $\quad 630$

(C ICAS / Amsterdam University Press, Amsterdam 2009

All rights reserved. Without limiting the rights under copyright reserved above, no part of this book may be reproduced, stored in or introduced into a retrieval system, or transmitted, in any form or by any means (electronic, mechanical, photocopying, recording or otherwise) without the written permission of both the copyright owners and the authors of the book. 


\section{Table of Contents}

$\begin{array}{ll}\text { List of Tables and Charts } & 7\end{array}$

Introduction $\quad 9$

I Inter-religious Debate at the Court of the Early Tang:

An Introduction to Daoxuan's Ji gujin Fo Dao lunheng 15

Friederike Assandri

2 Social Crises and Political Reform during the Jiaqing

Reign of Qing China, I796-I8Ios

Wensheng Wang

3 'China' on Display at the Chicago World's Fair of I893:

Faces of Modernization in the Contact Zone

Yuki Ooi

4 Christianity and State-Building in Republican Chaozhou, South China

Joseph Tse-Hei Lee

5 The Structure of Salt Distribution in Taiwan, I895-I945

89

Tsu-yu Chen

6 Semi-Colonialism and Cultural Interaction:

Chinese Indentured Labor in World War One France and the Sino-French Connection

Paul J. Bailey

7 China's Rise: Some Considerations

Dora Martins

8 A Snapshot of Internet Regulation in Contemporary China: Censorship, Profitability and Responsibility

Jinqiu Zhao 
List of Contributors

Index

I 55 


\section{List of Tables and Charts}

Table I.I Inter-religious court debates of the Early Tang Dynasty reported in T 2I04, $4 \quad$ I7

Table I.2 Nyāya sutras and Rushi lun catalogues of possible

Table 2.I Number of unsolved capital appeals in various provinces in I8IO

Table 5.I Organization and functions of the Taiwan Salt Affairs Bureau in 1899

Table 5.2 Changes in salt distribution network in Taiwan (I9I5-I944)

Table 5.3 Holders of special permits for salt production (I903) 97

Table 5.4 Japanese salt supply and demand I00

Table 5.5 Main marketing regions of Taiwanese salt and sales volumes (I899-I942)

IO2

Chart I.I The relative positions and roles of discussants and emperor

Chart 5.I The three step system 94

Chart 5.2 The two step system

Chart 7.I China's GDP evolution

$\mathrm{I} 22$

Chart 7.2 Chinese model for rise 



\section{Introduction}

This volume offers a selection of papers that were presented at the International Convention of Asian Scholars 2005 in Shanghai and in 2007 in Kuala Lumpur. In the best tradition of the ICAS conventions, the eight chapters in this volume present original and new research, introducing to-date unexplored, overlooked or ignored subject matter as well as new interpretations and evaluations of a wide range of historical and contemporary issues.

Covering a timeframe of more than I,400 years, this volume presents case studies that highlight new aspects and facets of the complex interactions that inform the course of Chinese historical and contemporary development and examine hitherto unknown or little known facets and phenomena of historical and contemporary China. Together, they underscore how China's historical and contemporary development is never a one-dimensional process, but a many-faceted, multi-level interplay of different, often opposing forces and agents within the evolving Chinese society and in China's emergence on the world stage.

Following the ups and downs of China's history, the research focuses on issues from the rising Tang dynasty, then passes to a period of decline during the Qing dynasty and to debates on modernization and state-building at the end of the nineteenth century and beginning of twentieth century, salt distribution in Taiwan, Chinese labor in France during the unstable period of World War One and finally to current considerations of China's rise and regulation of the internet.

These eight chapters focus on several episodes of Chinese history from an innovative research perspective, which considers a great range of actors such as officials, clergy, intellectuals, workers and the Chinese diaspora, as well as the interaction between Chinese people and foreigners of different origins.

Starting from the early Tang dynasty, Friederike Assandri focuses on a little-known institution of early medieval China: the inter-religious debates at the court of that period. She examines the institution of public inter-religious debate as a forum for interaction between the representatives of the religious communities of Daoism and Buddhism with each other and with the emperor during the early Tang period. Based on a detailed study of unique reports of a series of such court debates 
from the seventh century found in Daoxuan's Ji gujin Fo Dao lunheng (T 2104), she introduces scope, formal proceedings and rhetoric conventions of inter-religious court debates. She discusses Indian influences on inter-religious debates and on argumentative and rhetoric conventions, as well as their interplay with indigenous Chinese models of debate and dialogue. Furthermore, she shows how seemingly abstract religious or philosophical concepts were related to socio-political issues like the ranking of the religions at court, thus emphasizing the multi-level interaction and mutual influences of state and religion at the center of power in early medieval China.

Focusing on the Jiaqing reign of Qing dynasty, which is often associated with decline, Wensheng Wang analyzes the social crises and political reform during the Jiaqing reign (I796-I8Ios). He argues against the prevailing view of this period as the crisis-ridden beginning of dynastic decline after the prosperous Qianlong reign (I736-I796). Introducing the concept of sustainability into the discussion, he interprets the escalating upheavals during the last decade of the Qianlong reign as a crisis of an overloaded empire enmeshed in unsustainable political development. He draws attention to how the social crisis of the i7gos to I8Ios caused by the White Lotus rebellion inland and contemporaneous south sea piracy, triggered a pragmatic retreat that sought to pull Qing empire building back onto a sustainable track of development. Examining policy changes regarding the White Lotus sect, capital appeals, and tribute gifts, Wang re-evaluates the Jiaqing emperor's politics of retreat as a realistic and successful attempt to create sustainability of government, which produced a path-shaping conjuncture in the interlocking structural transformation of state and society.

The following three chapters present new perspectives on modernization, organization and state-building in the transition phase from late imperial to early republican China at the end of the nineteenth to the early twentieth centuries.

In the essay 'China on Display at the Chicago World's Fair of I893: Faces of Modernization at the Contact Zone', Yuki Ooi examines the Chinese presence at the World Columbian Exposition of 1893 held in Chicago. Describing the complex negotiations between China, the US, Chinese Americans, and other Americans, she interprets the World Fair as a contact zone of modernization, a space where ideas about modernization of American society and Chinese people in Chicago could be detected.

Discussing a time and context, where concepts of national identity and nation were just emerging, her case demonstrates how the identity of these Chinese in Chicago as Chinese emerged while they were simultaneously becoming Americans. Based on this emerging identity, she attempts to illuminate how the Chinese Chicagoans' ideas about moder- 
nization were influenced by the dual or trans-national identity of being Chinese and American and the reality of living in the dual social contexts of China and the United States. The chapter concludes that the Chinese migrants, while acquiring a Chinese American identity, were neither simply subjugated to nor assimilated into an American way of modernization associated with white supremacy, but instead, they negotiated and re-conceptualized modernization on their own terms.

In his chapter 'Christianity and State-Building in Republican Chaozhou, South China' Joseph Tse-Hei Lee provides a novel perspective on state-society mediation by looking at Protestant churches in the turbulent Chaozhou-speaking region of north-eastern Guangdong province in the first three decades of the twentieth century. Re-conceptualizing church-state relations as an integral part of religio-politics in Chinese society, Lee centers his discussion on the relationship between state power and religion, investigating the nature of religion and state power at the local or grassroots level of Chinese society with a social history approach. He explains how Chinese Protestant church leaders drew on a wide range of political and cultural resources in their search for a new basis for the Chinese state and nation in the transitional period between the collapse of the Qing imperial order and the establishment of the new modern state. They effectively employed the Christian missionary resources to achieve modernity by Western standards while maintaining a distinctive Chinese identity and pursuing their local agendas. Lee examines the complex interactions of Chinese Protestants, local society, foreign missionaries and the state in the process of nation-building and modernization in early Republican Chaozhou. His discussion ranges from the integration of the Western church model into traditional lineage and kinship networks, the expansion of the role of the Protestants as educators, modernizers, relief workers and conflict mediators, to the dilemma of the missions contributing to China's modernization and fostering the growth of new social and cultural forces that were antagonistic towards the missionary enterprises.

In the following chapter, the "The Distribution Structure of Taiwan Salt, I895-1945', Tsu-yu Chen offers new insight on an almost forgotten topic from studies on the salt trade: the organization of production and trade of this commodity during the Japanese rule in Taiwan. Chen explains the economic objectives of the promotion of the salt monopoly and complements them with a discussion of the political and social impacts of these efforts. She demonstrates how trade and monopoly were used by Japanese colonial powers in Taiwan as a catalyst for Taiwan's own development and to reduce its dependence on other countries. This salt-trade also had political effects, linking the economy of Taiwan to Japan, but separating Taiwan from mainland China. Chen describes the development from a monopoly policy aimed at filling the needs of Ja- 
pan without hampering its salt industry, to the investments of Japanese zaibatsu in Taiwan under the control of the colonial government owing to modernization of the salt industry, which then created monopoly capitalism. This is the transformation of the salt trade from an importsubstitution to an export-oriented industry, a strategy used many decades later by Japan and afterwards by the small 'dragons' of Asia, including again Taiwan, to develop their economies. The author also explains social consequences of such trade such as the intricate links between different social players in Taiwan and Japan. Taiwanese salt wholesalers, selected by the authorities, benefited from the monopoly policy, accumulated capital and became the new gentry, which closely cooperated with the colonial government. Chen Tsu-yu argues that the salt distribution network aided the colonial government in controlling Taiwanese society, and at the same time, it furthered social development and ultimately was instrumental in the industrialization of Taiwan.

The following two chapters present new insights into issues concerning China's role at the international level during two different periods: World War One and more recently since the end of the Cold War.

In his chapter 'Semi-Colonialism and Cultural Interaction: Chinese Indentured Labor in World War One France and the Sino-French connection' Paul Bailey focuses on a little-known episode, which occurred during World War One: the recruitment of Chinese labor for war-related work in France. In contrast to the image of a passive victim of semi-colonialism, China demonstrated the intention of playing a more active role at the international level, which may have begun by active participation in the Paris Peace Conference. According to the author, this is one of the reasons for China's official positive response to the French request for China labor at that time. Another reason is connected to the influence of Francophile intellectuals who cultivated deep links with Chinese politicians and French officials and intellectuals. Finally, the author documents that the Chinese were involved in a wide variety of jobs related to France's war efforts and partially responded to labor shortages in France. In contrast to the coolies at the end of the nineteenth century, who had come as indentured laborers from Asia to the colonies, these workers claimed good working conditions, often protesting if something was not right. The chapter concludes by highlighting the long-term political significance of the episode, arguing that the Chinese government's political use of Chinese labor in World War One anticipated the foreign policy of the post-I949 Maoist state in its relations with Africa.

Analyzing a more contemporary topic, in her chapter 'China's Rise: Some Considerations', Dora Martins discusses how, half a century later, the emerging China started to use the 'peaceful rise' as the core of its foreign policy discourse. As Chinese economic power was rising, the 
political leaders started to use the 'peaceful rise' slogan to lessen other countries concerns regarding its intentions. After a brief assessment of features of China's contemporary rise, the author explains how the concept of 'peace' and 'rise' has been used in Chinese culture and throughout Chinese history. As a response to the recent resurgence of the theory that China is a threat put forth by some countries, the Chinese government started to use the concept of 'China's peaceful rise'. In fact, this concept is not new and may be understood as a continuation of the 'peace and development' used by Deng Xiaoping as a guideline of China's foreign policy from the early eighties. The author questions whether China is indeed following a peaceful path while emerging, concluding that the current path of Chinese foreign policy is driven by three major features: economic diplomacy, cooperative and comprehensive security, and soft power.

The last article presented in this volume, Zhao Jinqiu's 'A Snapshot of Internet Regulation in Contemporary China: Censorship, Profitability and Responsibility', addresses one of the most recent developments during China's recent growth in power, the issues evolving from the growing use of the Internet in China, the tensions between the free architecture of the Internet, and the Chinese government's need to control it. Zhao reviews and evaluates China's attempts at regulating the Internet in the cases of two controversial issues confronting the Chinese government - news copyright and online satire. The study highlights the underlying tension in the current policies of the Chinese government, which promote a more open market economy while maintaining tight censorship over news media and freedom of speech, and discusses the socio-economic implications of Internet censorship on media, society and individuals in China.

Taken together, the different 'micro' facets of historical and contemporary issues and case-studies presented in this volume not only offer new perspectives in the study of the respective times and events discussed. They also portray in a kaleidoscopic fashion the complex multilevel interaction of different agents, which are at the heart of any historical and contemporary development, from intellectual debates to political and social dynamics, from economic politics to modernization, identity-building and state-building, from the center of power to the periphery of China to the Chinese diaspora and to Chinese international relations.

We would like to conclude with a personal word of thanks to Dr. Paul van der Velde, general editor of the ICAS Publications Series and initiator of this project, without whose concrete involvement in the selection of contributions and the publishing house this volume would not have come into existence. 



\title{
1 Inter-religious Debate at the Court of the Early Tang: An Introduction to Daoxuan's Ji gujin Fo Dao lunheng
}

\author{
Friederike Assandri
}

\section{Introduction}

This chapter introduces the institution of inter-religious court debate according to a to-date neglected source text, Daoxuan's Ji gujin Fo Dao lunheng (Collection of Critical Evaluations of Buddhism and Daoism from the Past and Present, $\mathrm{T}^{\mathrm{I}}$ 2104). During the Six Dynasties and the Tang dynasty inter-religious debate constituted a forum of intellectual exchange between Daoists and Buddhists and between secular authorities and clergy. A detailed study of Daoxuan's reports allows us for the first time to describe the rhetoric characteristics and formal proceedings of these debates.

In early medieval China, Buddhism and Daoism influenced each other as they developed, yet documentation of their meeting points is scarce. Court debates represent a comparatively well-documented forum where Daoism and Buddhism were in direct contact. Debate in various forms was an important part of the intellectual life of the literati elite in early medieval China.

Studies of the introduction and spread of Buddhism in China have demonstrated that the tradition of 'pure talk' (qingtan 清 談), an indigenous Chinese form of debate, was instrumental in the spread of Buddhism among the literati (Zürcher I959: 95, I59). In addition, Buddhists also fostered scholarly debate following Indian customs of debate.

Travelling masters challenged each other on specific points of doctrine or on debates about texts (Tang I938: 200-203).

After the revelations of the Daoist Highest Clarity (Shangqing) and Numinous Treasure (Lingbao) scriptures in the last quarter of the fourth century, which were geared to the tastes of the educated elite (Bokenkamp I997: 278), literati circles became increasingly interested in Daoism.

During Six dynasties, Daoists as well as Buddhists gained access to the highest levels of society and to the imperial court in the south and in the north of China. The situation of the divided empire had under- 
mined traditional legitimation of the emperor as the son of heaven; the many emperors of the new smaller states needed to find new legitimating strategies. Buddhism and Daoism vied to offer such strategies, often in return for imperial patronage and material support.

As of the fifth century, apologetic writings (e.g., Sengyou Hongming ji T 2102, Daoxuan Guang hongming ji T 2103) document a strong competition between the adherents of the two religions in the environment of the courts (Schmidt-Glintzer I976, Kohn I995).

Increasingly, the protagonists who shaped the development of Buddhism and Daoism were in some way or other tied to the court. Imperial sponsorship allowed the Buddhist translation academies to function and finance libraries; it seems that by the Sui and the early Tang dynasties joining the great monasteries located in the capital Chang'an was 'a dream' for many educated monks (Daoxuan Xu Gaoseng zhuan T 2060, I5: 547b). Many of the Daoist masters instrumental in shaping the formation of Daoism in early medieval China had ties to the courts as well; several of them engaged in court debates against Buddhists (Assandri 2004: 546-575).

One reason for the growing attraction of the imperial court for Buddhists and Daoists was certainly the increasing grip of the state on religious institutions. Intensified administrative control, but also generous imperial patronage (Benn I977, Weinstein I973) ultimately led to close relationships between the leaders of the clergy of both religions in the capital and the secular powers. Buddhists and Daoists who were invited to debate at court were members of the intellectual, religious and social elite of their times, often well acquainted with eminent personalities or with the imperial family.

Inter-religious court debates became an important arena of interplay for political authorities and religious communities and of competition between the religious communities. Several emperors held such debates, sometimes with the clearly stated aim of deciding which of the two teachings was the better for the state, sometimes with the aim of bringing general blessings for the empire (Assandri 2004: 36-68).

\section{The Ji gujin Fo Dao lunheng (T 2104)}

While references to court debates between Buddhists and Daoists in the official and religious histories of the Six Dynasties, Sui and Tang are numerous, they are usually too fragmentary to provide a clear picture of these debates. An important exception is the fourth chapter of the Ji gujin Fo Dao lunheng (T 2IO4), which contains a collection of detailed reports on inter-religious court debates between Buddhists and 
Daoists, held between 658 and $66_{3}$ at the court of Tang emperor Gaozong (r. 650-683).

Table 1.1 Inter-religious court debates of the Early Tang Dynasty reported in T 2104, 4

\begin{tabular}{|c|c|c|}
\hline Date & Place & Occasion \\
\hline Xianqing 3 (659), $4^{\text {th }}$ month & Imperial Palace, Hebi hall & \\
\hline $\begin{array}{l}\text { Xianqing } 3(659), 6^{\text {th }} \text { month, } \\
12^{\text {th }} \text { day }\end{array}$ & Imperial Palace, Linde hall & $\begin{array}{l}\text { Emperor's birthday and } \\
\text { inauguration of Ximing } \\
\text { temple }\end{array}$ \\
\hline Xianqing 3 (659), $11^{\text {th }}$ month & Imperial Palace & Sacrifice to bring about snow \\
\hline $\begin{array}{l}\text { Xianqing } 5(661), 8^{\text {th }} \text { month, } \\
18^{\text {th }} \text { day }\end{array}$ & Imperial Palace of Luoyang & \\
\hline $\begin{array}{l}\text { Longshuo } 3(664), 4^{\text {th }} \text { month, } \\
14^{\text {th }} \text { day }\end{array}$ & Imperial Palace, Penglai hall & $\begin{array}{l}\text { Note: Two days later, } \\
\text { Gaozong issued the edict that } \\
\text { the monks had to bow in } \\
\text { front of their parents. }\end{array}$ \\
\hline $\begin{array}{l}\text { Longshuo } 3(664), 5^{\text {th }} \text { month, } \\
16^{\text {th }} \text { day }\end{array}$ & Imperial Palace, Penglai hall & \\
\hline $\begin{array}{l}\text { Longshuo } 3 \text { (664) } 6^{\text {th }} \text { month, } \\
12^{\text {th }} \text { day }\end{array}$ & Imperial Palace, Penglai hall & Emperor's birthday \\
\hline
\end{tabular}

The Ji gujin Fo Dao lunheng is a record of the competition between Buddhism and Daoism since the introduction of Buddhism in China. Its author, the Buddhist Daoxuan, presented this document to the throne in 664. It is part of the Buddhist apologia in a time of intense competition between Buddhism and Daoism at court, but also between clerics and the secular authorities. ${ }^{2}$ This context has to be considered when interpreting the reports. The fact that all the debates reported end in favor of the Buddhists raises questions: Were the Daoists not up to their Buddhist counterparts or did Daoxuan falsify and distort the reports? Or else, did he selectively report only the debates where the Buddhists won?

Professor Luo Xianglin (1906-1978) from Hong Kong University has proposed the Daoists were no match for the Buddhists (I955: I65). However, a study of the biographies and writings of the Daoist participants in the debates (Assandri 2004: I54-I68) suggests that the Daoist were highly qualified and well versed in their own scriptures as well as in Buddhist teachings. Instead, we can confirm that Daoxuan reported selectively: there are references to debates in contemporary texts, which Daoxuan did not include in the Ji gujin Fo Dao lunheng. ${ }^{3}$

With regard to the question of the reliability of the reports, we do not have any texts to conduct a cross-reference check. But we may speculate: The Ji gujin Fo Dao lunheng was presented to the emperor Gaozong, in front of whom all the debates reported in the fourth chapter were held. There is evidence that at the time Gaozong favored the Dao- 
ists over the Buddhists (Assandri 2004: I48-150). We assume that under such circumstances a major distortion of the reports would have been noticed and censured.

Combining these detailed reports with fragmentary information from other sources, we can describe the workings and proceedings of the court debates of the Six Dynasties and Tang dynasty.

\section{The purpose of inter-religious court debates}

Inter-religious court debates in early medieval China had two different purposes: they aimed to be pragmatic competitions of participants to determine who was better, more profound or more efficient in helping the emperor and the state, and they also aimed to educate and entertain the audience.

Debates tending towards the pragmatic purpose often concerned the relationship of clerics to the state and the question to what extent the religious community could ask for independence from the socio-political rules of the state. This type of debates prevailed in times when the emperor was seeking ideological tools to rule, or when he was trying to intensify control over the religions. Examples of debates with a pragmatic orientation are the debates held under the Emperor Wu of the Northern Zhou dynasty in 569-573 (Kohn I995: 3I), as well as the earlier debates in the south about the independence of the Buddhist sangha (Zürcher I959: 254-288 and Kohn I995: I7-2I). The pragmatic aspect prevailed also in the debates at the court of the first two Tang emperors. ${ }^{4}$ At other times, especially under the third Tang emperor Gaozong, entertainment and education was the principal purpose for debate.

\section{Polemics, jokes and ridicule}

The text of the Ji gujin Fo Dao lunheng as well as the institution of court debates have so far not received much scholarly attention. In fact, at first sight the text discourages study and even suggests that the debates don't offer much insight for a serious researcher: The debates consisted of extremely concise and difficult verbal exchanges, mixed with large quantities of polemics and invectives, like the following:

Daoist Li Rong, the hair hanging down from your head makes it look like the head of a sheep. On your mouth, there is a moustache; it looks just like a deer's tail! Your mouth is barely good enough for small snacks, but not to discuss literature! ... When you raise your hands to greet, it looks like donkey's hoofs being raised, when you move your legs, it looks as if you are swaying on the knees of a crane! (Daoxuan T 2104, 4: 392a27). 
This certainly does not fit with our idea of a serious philosophical or spiritual environment - after all, we are talking about the elite of Buddhism and Daoism of the time!

These rather crude polemics have discouraged the study of the text and of court debates in general. However, it is here that we have to reconsider our own assumptions: Who says philosophical debate has to be serious, sober, and unsmiling? In fact, it seems that polemical ridicule was fashionable among intellectuals and 'high society' at that time. The thirteenth chapter of the New Tales from the Great Tang ( Da Tang xinyu) contains a section 'Ridiculing' (Xiexue 諧謔), which starts with the comment: '[Emperor] Taizong (r. 627-650) often approached his ministers and ordered them to ridicule each other, which amused him greatly' (Liu Su, Da Tang xinyu: I35). The chapter continues to list amusing polemics and ridicule from well-known contemporary personalities. ${ }^{5}$ Presumably, this kind of polemical ridicule had been popular for a long time: The Taiping guangii (Extensive Records of the Taiping Era), chapters 245-257, lists under the headings 'Jokes' (Huixie 詼諧) and 'Mockery' (Chaoqiao 嘲 誚) many similar examples of polemical ridicule. One example is part of a debate, which concluded a Buddhist lecture organized by emperor Gaozu (r. 550-557) of the Qi dynasty (Taiping guangii, 247: I9I5-I9I8). Others report many different witty polemical exchanges of famous personalities from the Han through the Tang dynasties. ${ }^{6}$ Only a small part of the entries rely on information from official historiographies; the major part of the entries cites two texts, Record of Explaining Countenance (Qiyan lu 啓顏 錄) (Six Dynasties - Sui) and Concourse of Conversation (Tansou 談 藪 ) (Tang). These texts are listed in the bibliographical section of the dynastic histories under the heading 'Xiaoshuo' (小説) 7 together with several texts with titles containing additions like 'Forest of Debate' (bianlin 讋 林), 'Leisure Talk' (xiantan 閑談), 'Playful Talk' (jutan 劇談), ${ }^{8}$ suggesting that they may have contained witty polemical verbal exchanges as well. ${ }^{9}$

The detailed analysis of argumentative strategies in the debates (Assandri 2004: II4-II7) shows that the polemics were integrated into the court debates with a precise function, namely they presented a legitimate way out of an impending defeat.

\section{Indian influences}

In the court debates reported by Daoxuan, elements reminiscent of indigenous Chinese traditions, like 'pure talk' (qingtan) and witty polemics combine with elements from the Indian tradition of scholarly debate. 
Table 1.2 Nyāya sutras and Rushi lun catalogues of possible mistakes in debate

Nyāya-sutra catalogue of the 22 mistakes Rushi lun catalogue of mistakes

(Stcherbatsky 1962: 340-341)

(Xu 1928: 141-142)

1. Annihilation of one's own thesis (by an

1. Hurting the Proposition' (huai zi li yi 壞自 unsuitable example)

立義)

2. Shifting to another thesis (during the same debate)

3. A contradictory thesis

4. Abandoning one's own thesis

5.-6. Changing the reason or the topic

2. Shifting the Proposition (qu yiyi 取異議)

3. Opposing the Proposition (yin yu liyi xiangwei 因與立義相違)

4. Renouncing the Proposition (she zi liyi 捨

自立義)

5. Shifting the Reason (li yi yinyi 立異因義)

7.-10. A meaningless,

6. Shifting the Topic (yiyi 異義)

7. Meaningless (wuyi 無義)

unintelligible,

8. Unintelligible (you yi bu kejie 有義不可解)

incoherent,

9. Incoherent (wu daoli yi 無道理義)

or inopportune argument

10. Inopportune (bu zhishi 不致時)

11.-12. Insufficiency or

redundancy in expression

11. Saying too little (bu juzufen 不具足分)

12. Saying too much (changfen 長分)

13. Repetition (chongshuo 重說)

14. Silence (bu neng tong 不能通)

13. Repetition

14. Silence

15. Confession of ignorance

15. Ignorance (bu jie yi 不解義)

16. Failing to understand (the question)

16. Non-ingenuity (bu neng nan 不能難)

17. Stopping the debate under the pretext of

17. Evasion (li fangbian bi nan 立方便避難)

going to attend another business when

seeing that the defeat is inevitable

18. (Indirect) admission of a charge

18. Admission of an [opponents] opinion (xinxu ta nan 信許他難)

19.-20. Neglecting to rebuke the questioner when it is necessary or doing so when it is not necessary

21. Not keeping faithfully to one's own principles

22. Fallacious logical reasons

19. Overlooking the censurable (yu duofuchu bu xian duofu 于隋負処不顯隋負)

20. Censuring the non-censurable (feichu shuo duofu 非処說墮負)

21. Deviating from the tenet (wei xi tan duo suo wei 為悉檀多所違)

22. Semblance of a reason, or fallacy (siyin 似因)

During the Six Dynasties, a Buddhist master would be distinguished not as belonging to a certain school, but rather as an expert on a certain text. This expertise had to be confirmed in debates against challenging masters (Tang 1982: 20I, 209). Conventions of debate as practiced in India must have found attention in China with the introduction of the different Buddhist Śāstras, which had originated in India in an environment of competing schools of thought ${ }^{\mathrm{to}}$. In fact, there are several fifth and sixth century translations of Indian eristic texts: The 
Fangbian xinlun ('Essay on the core of expedient means', Upāya-kauśalyahrdaya-śastra), T I632, translated in $472^{\mathrm{II}}$ by Jijiaye and Tanyao in the state of Wei ${ }^{\mathrm{I} 2}$, the Huizheng lun ('Essay on refuting disputes' Vigraha Vyavartani kārikā), T I63I, translated 54I in the state of Liang, and the Rushi lun (Tarkaśastra), T I633, translated in 549 by Paramārtha in the state of Liang (Tucci I929 and Xu Dishan I928). These texts contain rules on how to present and prove a logically correct thesis, and very detailed lists of possible mistakes of the defendant and the opponent, which were probably intended as a manual for the arbiter of a debate. They are similar to the listings found in the Indian texts on logic and eristic, the Nyāya sutras, as table I.2 shows.

This Buddhist tradition of debate may have gained popularity with Xuanzang's (600-664) report from his travels in India. As of 645 this great Buddhist scholar and translator, who had travelled and studied extensively in India, taught and worked in the capital Chang'an. In India, he had successfully taken part in the grandiose inter-religious court debates organized by the Indian emperor, and accounts of the debates figure prominently in his report 'Records of the Western Regions from the Time of the Great Tang' (Da Tang xiyu ji T 2087). Xuanzang introduced a new form of logic, the Indian hetuvidyā (yinming 因 明) ${ }^{\mathrm{I} 3}$, to chosen disciples as a powerful tool in debate. He also translated an essay on Seven Points of Debate, which is contained in almost identical versions in seven different texts he had translated. ${ }^{\text {I4 }}$ The seven points of debate refer not only to intellectual aspects of debate like the correct proposition of a thesis and possible logical mistakes; they also discuss the context of debate, such as the place and general conditions for debate as well as the qualities of the debater:

I. Lun tixing 論體性 The general character of speech. This part lists different types of speech; positive, like laudatory or educating speech, and negative, like polemical or belligerent speech.

2. Lun chusuo 論處所 The place of debate. Appropriate places to hold a debate are a royal palace, mansions of high officials, public meeting places, an aggregation of scholars and wise men, of monks, or of people who accept the Buddhist teaching.

3. Lun suoyi 論所依 The basis of a thesis. This central point explains in detail how to propose and prove a logically correct thesis. It is the core of the seven points.

4. Lun zhuangyan 論莊嚴 Dignified and brilliant speech. This section presents a long and detailed list of the characteristics of excellent rhetoric and of a brilliant orator. The description covers speech, logic of argumentation, outward appearance, behavior and manners of the speaker (Assandri 2004: 203-206).

5. Lun duofu 論墮負 Mistakes. This section lists in detail the mistakes leading to defeat in debate, comprising logical mistakes as well as 
mistakes in behavior, such as impoliteness or aggressiveness (Assandri 2004: 206-209).

6. Lun chulizhe 論出離者 Compatibility of the speech with what is considered generally good or fortunate. This section contains a summary of sine qua non conditions to consider before starting debate. The debater has to be convinced of the positive result of the debate; he has to make sure the audience will be able to understand the debate and he has to be sure that he is well versed in his own and in his opponent's teachings.

7. Lun duo suo zuo fa 論多所作法 Rules for the accomplished debater. This section summarizes three essential characteristics of a good debater: He has to have perfect knowledge of his own and his opponent's teachings, he has to be fearless in front of any kind of audience, and he has to have rhetorical talent.

The rules presented in the different manuals and eristic texts seem to have been applied in the court debates to a certain extent, however, there were also divergences.

Indian debate had found much interest among the Buddhists. The terminology used in the debates shows that the Buddhists were familiar with the Indian rules of debate and applied them ${ }^{\text {I5; }}$ however, the Daoists were not.

\section{The formal proceedings}

On a special occasion, e.g., the imperial birthday or a special sacrifice, well-known clerics of Buddhism and Daoism were invited to debate at court. In the Northern Zhou and under the first two emperors of the Tang dynasty as well as in some cases in High Tang, a representative of Confucian teachings, often a high-ranking minister or scholar of the Imperial Academy, also participated (Assandri 2004: II8). The audience of the debate typically included the emperor, the imperial family, officials and scholars from throughout the whole empire. There were also cases, where princes, provincial governors, or high officials organized such debates in their mansions ${ }^{\mathrm{I} 6}$ (Daoxuan $\mathrm{T}$ 2104, 3: $383 \mathrm{a} 28$; T 2060, 3: 442a).

The host, often the emperor, had the role of the arbiter. He opened the debate and proclaimed the subject to be debated. Then he invited in strict observance of the official ranking order of the teachings - the defendant to take his seat on the raised platform. The chosen defendant started with a eulogy on the emperor. This eulogy was composed of standard expressions, a set of stock phrases, which we also find in the official correspondence of ministers or other people with the em- 
peror of the time. Daoxuan reports the eulogies presented, sometimes shortened, in almost all of the debates he documented.

The eulogy, and the importance conceded to it by Daoxuan in his reports, emphasises that apart from the complementary positions of speaker/hearer there was the position of the emperor not merely as a hearer, but as the actual recipient ${ }^{17}$ or addressee of the debate.

Chart 1.1 The relative positions and roles of discussants and emperor

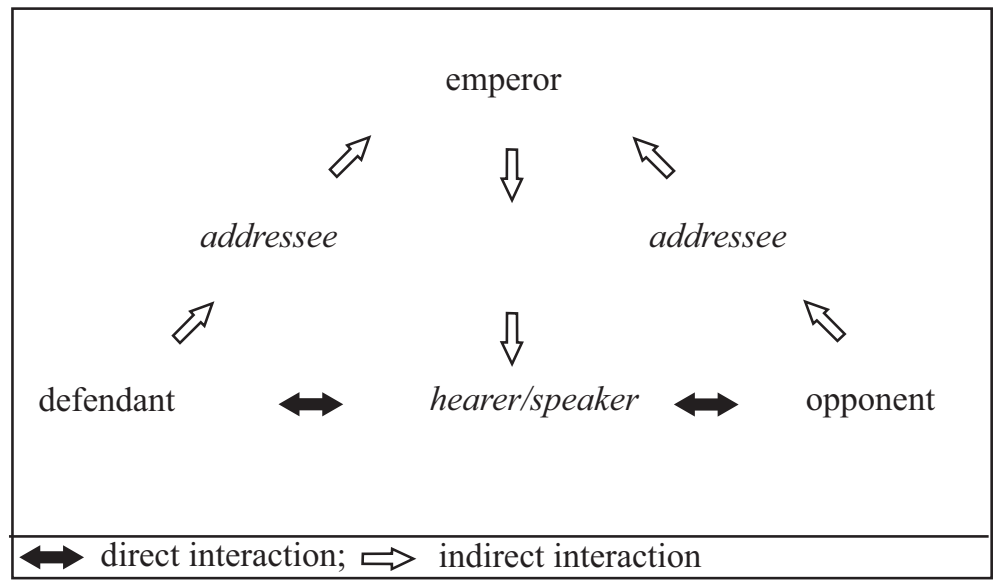

Thus, in any debate there was a level of direct interaction between opponent and defendant and a level of indirect interaction of the participants with the addressee, the emperor. The level of indirect interaction with the emperor conditioned the choice of argumentation.

After the eulogy, the defendant proposed his lecture. This was traditionally about a text, but under Gaozong we also find the proposition of a thesis. Nevertheless, it seems that the thesis was often based on the title of a text, such as 'benji yi' 本際義, 'thesis on the concept of original time', based on the Daoist Sutra of Original Time (Benji jing 本際 經) (Daoxuan T 2104, 4:389c). The lecture presenting a text is reminiscent of the dharma meetings (fahui 法會), held at the courts of the southern dynasties, especially of the Prince of Jingling (460-494) and Liang Wudi (r. 502-549), which began with a lecture on a Buddhist text (Jansen 2000: 95f).

Daoxuan in no case gives us a full report of a lecture, but we have an intact example of a lecture presented at the emperor's birthday on the $2 \mathrm{I}^{\text {st }}$ day of the fourth month in 792 in the Linde hall of the imperial palace: The Da fangguang Fo huayan jing xuanyi (Jingju T I743). ${ }^{\mathrm{I}} \mathrm{A}$ comparison of the fragments of lectures reported by Daoxuan in $\mathrm{T}$ 2IO4 with the Da fangguang Fo huayan jing xuanyi suggest that this lec- 
ture's structure was similar to the ones held during the early Tang period (Assandri 2004: 79), as the following example of the respective explanation of the title of the text presented shows.

The title Da fangguang Fo huayan: 'Da fangguan' designates the teaching, 'Fo huayan' designates the man. Furthermore, ' $d a$ ' (big) means the substance is omnipresent; 'fangguang' (emit rays) means, the effect is everywhere. Depending on substance, effect rises. This is meant by 'da fangguang'. 'Fo' (Buddha) is the man who realized and said [this truth]. 'Huayan' (the garland) means... This is why the sutra is called Da fangguang Fo huayan jing. (Jingju T I743: 1065a)

This excerpt can be compared with a fragment of a lecture from the early Tang period:

The thesis I will present today is Mahāprajñāparamitā. This is the elephant chariot of Mahāyāna... 'Mahä' means great, 'prajñ $\bar{a}$ ' means wisdom. 'Paramitā' means to reach the other shore. With regard to this term, not even [the expression] 'dark source' is apt to exhaust its profoundness and brilliance, that is why we rely on the word 'great' to contemplate it. Not even a mirror of water can symbolize its purity and clarity. This is why we rely on the word 'wisdom' to explain it... (Daoxuan T 2104, 4: 390b)

This and other fragments of lectures in Daoxuan's report ${ }^{\mathrm{I} 9}$ suggest that the structure of the lecture as visible in T I743 may have been standardized, consisting of the following elements:

I. Short summary of content of the Sutra, listing the chapters with titles and number of juan.

2. Explanation of the chapter titles.

3. Interpretation of the single characters of the title of the Sutra.

4. Description of the contents of each chapter.

5. Summary connecting the chapter contents (4) with the single characters of the title of the Sutra explained in step (3).

6. General remarks on Buddhism and wishes of blessing for the imperial birthday.

It is noteworthy that a very similar structure can also be found in longer texts such as Tiantai Zhiyi's Fahua xuanyi (Hurvitz I960-1962: 205297) or Cheng Xuanying's Daode jing kaiti xujue (Yan Lingfeng I983: 239-264 and Robinet 1977: 227-260). It seems possible, that these texts grew out of an original presentation. 
Only after the initial lecture, the emperor designated the opponent, who then went to take his seat on the podium. Like the defendant before him, he started with a eulogy on the emperor. After the eulogy, he proposed his first objection to the lecture. This started the actual debate, consisting of concise objections and answers.

Each objection required an immediate answer. As stipulated in the Indian rules of debate, inability to answer an objection or incomprehensibility would cause defeat. Differing from the Indian rules, in cases of an imminent defeat these debates allowed participants to switch to polemic ridicule of the opponent or to change the subject. These polemics and witty diversions into unrelated subjects like literature take a form reminiscent of the pure talk (qingtan) debates of the Six Dynasties. If even this strategy of evasion did not help, the emperor declared defeat. Whatever the tone of an objection was, serious or polemic, it seems to have been mandatory to reply immediately on the same level of discourse.

The use of paraphernalia, such as the flywhisk (zhuwei 塵尾), was interesting. Every debater was equipped with a flywhisk. When answering, the debater raised the flywhisk, when he could not respond or was defeated he lowered it. Daoxuan mentions this explicitly in the reports (T 2104, 4: 390aig, Assandri 2004: 52-54).

In the earlier debates, when a defeat was declared, the debate was ended. Instead in the debates of the Xianqing era (656-66I) we find teams of seven participants on each side, taking turns until victory was declared. Once a defendant was defeated, he had to leave the debater's seat. A new defendant was chosen from the winning team, who then took the seat and proposed his new thesis (Daoxuan T 2104, 4: 387c). If instead an opponent was defeated, he left his seat and a new member of his own team took the opponent's seat to debate against the the original defendant (Daoxuan T 2104, 4: 389c). In this way, a debate could last for more than a day (Daoxuan T 2104, 4: 393b).

A victorious debater would usually receive lavish presents of silk and clothes from the emperor. Often the emperor offered him an important position in a monastery or even asked him to become an official - a request, which was declined in all the cases Daoxuan reported.

\section{Strategies of argumentation}

Argumentation in the inter-religious debates followed three major strategies: pointing out a contradiction with scriptural authority, logic and analogy.

Pointing out a contradiction with the authoritative texts was the most important and most frequent strategy. Quotations from the sacred texts of Buddhism or Daoism, as well as from the classics or historical re- 
cords constituted valid proof in a debate. Actually, the discussants used the classics as a kind of 'toolbox' to extract proofs for their theses, sometimes even distorting the citations. If a statement from the classics contradicted a logical conclusion or deduction, the statement from the classic prevailed as the essential proof (Daoxuan T 2104, 3: 38rbio; 4: 38 gb3).

Nevertheless, debaters also used argumentative strategies based on logical reasoning. Several Buddhist texts of that time contain examples of logical refutation of heretic views, like Cheng weishi lun (T I585, I), Xianyang shengjiao lun ( $\mathrm{T}$ I602, IO, II, I2, I6), and Yujia shidi lun ( $\mathrm{T}$ I579, 6,7). Generally, these texts also refer to the Daoist teaching of Laozi and Zhuangzi, which they subsume in the category of 'Heretics [believing in] the Of-itself-so' (ziran waidao自然外道). The strategies proposed in these texts were used only in two cases by the Buddhists Huili (6I5- ca. 675) and Lingbian (ca. second half of the seventh century), both disciples of Xuanzang (T 2104, 4: 387 and 393).

Xuanzang introduced yinming logic to his disciples. This Indian logic had not only epistemological value, it was also a highly efficient weapon in debate. Huili employed it once in debate ( $\mathrm{T}$ 2104, 4: 387c-388a; Assandri 2004: 257-266). Although he carried away a great victory in that debate, Buddhist yinming logic did not become popular with the Buddhist debaters.

A far greater number of discussants relied on the logic of reductio ad absurdum, the prasanga method introduced in China with the Mādhyamika school of Buddhism. Not only the Buddhists, but also the Daoist participants were versed in this type of logic, which therefore offered more possibilities of dialogue.

Analogies were used frequently and treated very carefully. The single terms used in analogies were analyzed in detail to prove the validity, or lack of an analogy. When an analogy was proved as inappropriate, this was considered a valid refutation of the opponent's argument.

\section{Some remarks on the contents of the debates}

The subject, which the Buddhists and Daoists in the debates of the early Tang period discussed most often, was the concept of Dao as the origin of all being and at the same time original non-being ( $\mathrm{T}$ 2104, 3: 38rb; 4: 387c, 390a, 393b). In Daoism, these two conceptions of Dao stand as a paradox. The Buddhists repeatedly attacked this paradoxical interpretation of the Dao. The Daoists, mostly representatives of 'Twofold Mystery' (chongxuan 重玄) teaching (Assandri 2005), tried to explain the paradoxical relationship of being and non-being, e.g., in Cheng Xuanying's commentary to the first chapter of the Daode jing 
(Yan Lingfeng 1983: 295). However, in the debates it became obvious that these explanations were not yet mature enough to withstand a confrontation with the Buddhists.

Discussion about the aspects of Dao as eternal non-being and origin of all being was complicated by the fact that the Daoists of the early Tang regarded Laozi, reputed author of the Daode jing, as a personification of the Dao, and therefore as identical with the Dao. During the Six Dynasties, Daoism had undergone a process of adaptation and integration of soteriological and cosmological concepts from Mahāyāna Buddhism. This process was well advanced but not fully matured by the early Tang. In particular, the association of soteriological aspects of Dao personified in Laozi with the cosmogonic aspect of Dao as beginning and origin of all being caused difficulties in the debates. The Buddhists seem to have been aware of the problem, since they attacked the subject repeatedly.

The amalgamation of cosmogony and transcendence in the term Dao in Daoism represents one of the fundamental differences of the two teachings. In Buddhism, cosmogony is part of the circle of life and death, dependent on conditioned causation and completely separate from the transcendent. Daoism and Buddhism had assimilated many of each other's practices and concepts in the course of the Six Dynasties, but at this point, there remained an unbridgeable difference. However, the reasons for the heated debates on the thesis of Dao as origin of all being were not only of a philosophical nature. There was a rather practical issue involved: the question of the official ranking of the teachings in the state. ${ }^{20}$

One important argument in the competition for the first place in the official ranking of the teachings was the relative age of the 'founders' or 'lords' (jiaozhu 教主) of the teachings (T 2110: 499a; Assandri 2004: 455-459). The relative ages of Laozi, often referred to as founder of Daoism, and Buddha had been a major issue discussed also in the context of the 'conversion' debate (huahu 化胡), the debate on the theory that Laozi, after leaving China, went to India to become the Buddha and convert the Barbarians.

The gist of the underlying argument was that if the Dao, in this context identified with its personification Laozi, was the beginning of all being, it must have been also prior to the Buddha. With this kind of argumentation the conversion (huahu) debate, which was originally concerned with the historical persons Laozi and Gautama Buddha, was transposed to a cosmic level. Yet, the underlying question, of whether Buddha or Laozi was first, remained. The importance of this question in the context of the competition in the official ranking may hinge on the Chinese Confucian cardinal virtue of piety: the younger owes re- 
spect to the older, and in an official ranking must certainly have the lower position. ${ }^{2 \mathrm{I}}$

It is noteworthy that in many of the debates on the Dao Buddhists as well as Daoists had terminological difficulties. The discussants rarely managed to discuss the different aspects of Dao separately. Although there were attempts to define the term Dao and to distinguish different connotations (Daoxuan T 2I04, 3: 38Ic), more often than not, debaters did not distinguish between the different aspects, leading to misunderstandings and confusion in debate.

Another frequently debated subject was to what extent language is adequate to describe the absolute, which is necessarily beyond the realm of definition by language. This question had been a focus of attention in the interpretation of the Daode jing for a long time. ${ }^{22}$ In the court debates, discussants analyzed this issue along the terms of the theory of the twofold truth, which Buddhism had brought to China. Buddhists and Daoists both used this theory very proficiently in the debates.

Apart from philosophical discussions mentioned so far, some debates also contained concrete criticism of Daoist contemporary practices by Buddhists. The attacks against the religious practice of Daoism in the debates correspond largely to the polemics in the different written apologies of the Six Dynasties. The main target of these attacks were the rituals of the Heavenly Masters as well as some cults closely related to popular religious practices.

The Daoist court debaters were 'representatives of the Twofold Mystery philosophy' and lived as celibate monks (chujiaren 出家人) just like their Buddhist counterparts. Interestingly, in no case did they claim their distance of the attacked practices and cults, which largely belonged to the Heavenly Masters tradition, a tradition which did not advocate celibacy. This demonstrates how the process of integration of different traditions in Daoism in the early Tang dynasty was well advanced.

One attack frequently levelled against the Daoists was the accusation that they plagiarized Buddhist scriptures. The Daoist reaction to such charges suggest that there must have been some solid ground for these accusations: in no case did a Daoist address such an attack by claiming authenticity of his texts. They preferred to change the subject or switch to polemics.

\section{Concluding remarks}

Daoism and Buddhism in China did not develop in a vacuum, but in a dynamic process, in which certain given sets of beliefs, ideals, ideas, and practices responded to outside stimuli. Socio-political circumstances like the interplay of the religious communities with the secular 
authorities, but also the dialogue or competition among different religious communities, were important stimuli in this process.

In inter-religious court debates different spheres of interaction are present all at once. This requires a multilevel reading strategy. Understanding the mechanisms, rhetoric and proceedings of court debates, enables us to get a glimpse of an important forum of interaction of Buddhists and Daoists in medieval China. Being oral exchanges, the debates reflect the interaction between Buddhists, Daoists, and the imperial court differently than written apologetic essays.

As documented points of 'direct encounter' of Buddhism and Daoism, the inter-religious court debates can open new perspectives on the development of Buddhism and Daoism in medieval China, as well as on specific issues such as the reception of Indian logic in China or the development of court Daoism.

\section{Notes}

I Trefers to the Taishō shinshū daizokyō edition of the Buddhist Canon, Tokyo, I924I932.

2 In addition to the Ji gujin Fo Dao lunheng Daoxuan had also presented the Guang hongming ji, T 2103. In 662, Yanzong had presented his Ji shamen bu ying baisu dengshi, $\mathrm{T}$ 2108, about the dispute over whether clerics should bow to the throne and to their parents.

3 See e.g., the biography of Li Xuanzhi in the Former History of the Tang (Jiu Tang shu), chapter I89b: 596a.

4 The debates under the first Tang emperor Gaozu developed largely around the famous II point essay of Fu Yi; see Daoxuan T 2104, 3: 379c.

5 Including e.g., Li Rong, one prominent Daoist debater of that time (Liu Su Da Tang xinyu: 136).

6 Compare Li Fang et al. Taiping guang ji: Han dynasty: three entries (chapter 245). Sanguo period: six entries (chapter 245). Jin dynasty: six entries (chapter 245), seven entries (chapter 246), eight entries (chapter 253). Dong Jin: three entries (chapter 246), Song: four entries (chapter 246), Qi: five entries (chapter 246), Liang: six entries (chapter 246), Chen: one entry (chapter 247). Northern Wei: three entries (chapter 247), Northern Qi: one entry (chapter 246) + nine entries (chapter 247) + one entry (chapter 253). Sui dynasty: eight entries (chapter 248); eight entries (chapter 253). Tang dynasty: I4 entries in chapter 248 , the complete chapters 249, 250, 25I, 252, $254,255,256$.

7 Xiao shuo in early medieval China was a designation for popular or entertaining literature in general.

8 See for example Sui shu, 34: I25a for two entries of texts with the title 'Bianlin', Xin Tang shu, 59: I65a: Rongmu xiantan and Kangpian jutan lu.

9 A comparison of the lists of titles, which suggest collections of polemical or witty dialogues, under the heading 'Xiaoshuo' in the bibliographical chapters of the Jiu Tang shu (chapter 47) and the Xin Tang shu (chapter 59) shows that this genre of literature seems to have been growing. This indicates that this kind of polemical ridicule gained popularity during Tang times. 
Io This refers to the Mādhyamika texts Zhonglun (T 1564), Shi'ermen lun (T 1568), Bailun ( $\mathrm{T}$ 1569), introduced by Kumārajīva, as well as the Yogācāra texts, introduced by Paramārtha.

II This text had previously been translated during the eastern Jin (3I7-420 CE) by Buddhabadhra, but that version was lost.

I2 465-47I CE was the reign of emperor Xianzu. Wei Shou wrote about this emperor: 'When Hsien-tsu mounted the throne, his earnest faith was most profound. He examined the various scriptures and treatises and delighted in Lao and Chuang. He always invited sramanas and gentlemen able to discourse on the mysteries, and with them discussed the essence of the Great Principle' (Hurvitz I956: 73). His son and successor held Buddhist scholarly debates and pure talk meetings as well (Tang I938: 5OI-502).

I3 Xu Dishan's term 'proposition' translates the same Sanskrit term as Schterbatsky's term 'thesis'.

I4 He translated the Nyāyapraveśa (Yinming ruzhengli lun, T I630) and the Nyāyamukha (Yinming zhengli men lun, T I628). For a study, see Frankenhauser 1996.

I5 In chapter 15 and I8 of the Yujia shidi lun (T I579, Yogācārabhumiśästra), in Dacheng apidamo jilun (T I605, Mahāyanābhidarmasańgitisiśastra), in Xianyang shengiao lun ( $\mathrm{T}$ I602, Prakaraņyāryavāacaśāstra) and in Zaji lun (T ı6o6, Dacheng abhidamo zaji lun; Mahāyānābhidharmasamyuktasańgītiśāstra).

I6 Cf. Assandri 2004: 216-43I for a detailed analysis of the rhetoric strategies in the debates.

I7 In these cases the emperor was not present, the host and his family were usually the highest ranking people present.

I8 Goodwin I990: 29I, in an analysis of context and dynamics of speech exchange uses the term 'recipient' as 'encompassing but not restricted to explicit addressees' in addition to the complementary terms hearer/speaker.

I9 The author of the text is Jingju from the Anguo monastery, about whom nothing else is known. There are no other records of this debate in 792; however, a debate in the Linde palace on the emperors birthday in the $12^{\text {th }}$ year of Zhenyuan is documented (Luo Xianglin I955: 169-170).

20 See in particular Daoxuan T 2104, 3: 383b, cf. Assandri 2004: 77-78 and 24I-244.

2I The official ranking of a religion in the state would have practical consequences regarding imperial patronage, permits to open tempels and to accept novices.

22 We should also remember that in the revelations of scriptures in southern Daoism of the Shangqing and Lingbao traditions one of the most important legitimizing strategies of the texts was the claim of revelation through a more ancient, more original god.

23 The best known of the treatment of this issue is Wang Bi's commentary to the Daode jing (cf. Wagner 2003: 44ff).

\section{References}

\section{Primary sources}

Bailun百論 (Śata-śāstra), T 1569 .

Cheng Xuanying 成玄英, Daodejing kaiti xujue 道 德經開題序訣 (Introduction and Preface to the Daode jing), in: Yan Lingfeng 嚴靈峰. Jingzi cong zhu 經子叢著, 239-264. Zhonghua congshu 中華叢書, vol. 6. Taibei: Guoli bianshi guan, I983.

Cheng weishi lun 成唯識論 (Vijñaptimātratāsiddhišāstra), T 1585.

Dacheng apidamo ji lun 大乘阿 毗達 摩集論 (Mahāyanābhidarmasańgitiśástra), T I605. 
Dacheng apidamo za ji lun 大乘阿 毗達 摩杂集論 (Dacheng abhidamo zaji lun; Mahāyānābhidharmasamyuktasańgitisśāstra), T I606.

Daoxuan道宣, Guang hongming ji 廣弘明集 (Expanded Records to Spread and Clarify [the Buddhist Teachings]), T 2103.

- Ji gujin Fo Dao lunheng 集古 今佛道論衡 (Balanced Discussion of Buddhism and Daoism in ancient and modern times), $\mathrm{T} 2 \mathrm{IO} 4$.

—Xu Gaoseng zhuan 續高僧傳 (Continued Biographies of Eminent Monks), T 2060.

Falin, Bianzheng lun 辩正論 (Essay on Discussing What is Correct), T 2IIO.

Fangbian xinlun 方 便心論 (Upāya-kauśalya-hrdaya-śastra or Upāya-hrdaya), T I632.

Huizheng lun 回諍論 (Vigraha Vyāvartani kārikāa), T I631.

Jingju 靜居, Da fangguang Fo huayan jing xuanyi 大方廣華嚴經玄義 (Profound Meaning of the Mahāvaipulya Buddhāvatamsaka Sutra), T I743.

Jiu Tang shu 舊唐書 (Former History of Tang Dynasty), Ershiwu shi二十五史, vol. 5, Shanghai: Shanghai guji chubanshe, I986.

Li Fang 李芳 et al., Taiping guang ji 太 平廣記 (Expansive Record of the Taiping Era), Io vol. Beijing: Zhonghua shuju, I96r.

Liu Su 劉肅, Da Tang xinyu 大唐新語 (New Talks from the Great Tang), ed. Wu Fenglong, Da Tang xinyu Wenbai duichao quanshi, Urumtchi: Xinjiang qingshaonian chubanshe, I995.

Rushi lun 如實論 (Tarkaśastra), T I633.

Sengyou 僧佑, Hongming ji 弘明集 (Records to Spread and Clarify [the Buddhist Teachings]), $\mathrm{T} 2 \mathrm{IO} 2$.

Shi'ermen lun十 二門論 (Dvadaśamukha-śāstra), T I568.

Song shi 宋史 (History of Song Dynasty), Ershiwu shi 二十五史, vol. 7, Shanghai: Shanghai guji chubanshe, I986.

Sui shu 隋書 (History of Sui Dynasty), Ershiwu shi, vol. 5, Shanghai: Shanghai guji chubanshe, I986.

Tiantai Zhiyi 天台智顗, Fahua xuanyi 法華玄義 (Profound Meaning of the Lotos Sutra), T I7I6.

Xianyang shengjiao lun 顯揚聖教論 (Prakaraņyāryavācāśāātra), T I602.

Xuanzang 玄牀, Da Tang xiyu ji 大唐西域記 (Records of the Western Regions written under the Tang Dynasty), T 2087.

Xin Tang shu 新唐書 (New History of the Tang Dynasty), Ershiwu shi, vol. 6, Shanghai: Shanghai guji chubanshe, I986.

Yanzong 彦琮, Ji shamen bu ying baisu deng shi 集沙 門不應拜俗等事 (A collection [of evidence] why Monks should not bow to lay persons), T 2108.

Yinming ruzhengli lun 因明入正理論 (Nyāyapraveśa), T I630.

Yinming zhengli men lun 因明正理門論 (Nyāyamukha), T I628.

Yujia shidi lun 瑜伽師地論 (Yogācārabhumiśāstra), T I579.

Zhonglun 中論 (Mādhyamikaśāstra), T I564.

\section{Secondary sources}

Assandri, Friederike (2004), Die Debatten zwischen Daoisten und Buddhisten in der frühen Tang-Zeit und die Chongxuan-Lehre des Daoismus. PhD thesis, Heidelberg University 2002. Ann Arbour: Proquest, UMI Dissertation Service.

- (2005), 'Understanding Double Mystery: Daoism in Early Tang as Mirrored in the FDLH (T 2104) and Chongxuan xue'. Journal of Chinese Philosophy 32 (3): 427-440.

Benn, Charles D. (I977), Taoism as Ideology in the Reign of Emperor Hsüan-tsung. PhD thesis, University of Michigan.

Bokenkamp, Steven (I997), Early Daoist Scriptures. Berkeley, Los Angeles: University of California Press. 
Frankenhauser, Uwe (1996), Buddhistische Logik in China. Wiesbaden: Harrassowitz.

Goodwin, Charles (I990), 'Conversation Analysis'. Annual Review of Anthropology I9: 283307.

Hurvitz, Leon (1956), Wei Shou: Treatise on Buddhism and Taoism: A Translation of the Original Chinese Text and the Annotations of Tsukamoto Zenryu. Kyoto: Jimbunkagaku kenkyusho.

-(1960-1962), Chih-I (538-597). An Introduction to the Life and Ideas of a Chinese Buddhist Monk. Mélanges chinois et bouddhiques XII. Bruxelles: Bruges.

Jansen, Thomas (2000), Höfische Öffentlichkeit im frühmittelalterlichen China. Freiburg: Rombach.

Kohn, Livia (I995), Laughing at the Dao. Princeton: Princeton University Press.

Luo Xianglin 罗香林 (I955), 'Tangdai sanjiao jianglun kao' 唐 代三教讲 论考 (Discussion on the debates of the three religions in Tang Dynasties) in Luo Xianglin (ed.), Tangdai wenhua shi 唐代文化史 (History of Tang Culture), I59-I70, Taibei: Taiwan Shangwu yinshuguan.

Mayer, Alexander L. (I992), Xuanzang. Übersezter und Heiliger. Wiesbaden: Harrassowitz.

Robinet, Isabelle (I977), Le commentaires du Tao tö king jusqu'au VII siècle. Mémoires de l'institut des hautes études chinoises. Paris: College de France, Institut des hautes études chinoises.

Schmidt-Glintzer, Helwig (I976), Das Hung-ming chi und die Aufnahme des Buddhismus in China. Wiesbaden: Harrassowitz.

Stcherbatsky, Theodor (I962), Buddhist Logic. New York: Dover.

Tang Yongtong 汤用娅 (I938), Han Wei liang Jin Nanbeichao fojiao shi 汉魏两晋南 北朝佛 教史 (History of Buddhism in Han, Jin and Six Dynasties), 2 vol., Shanghai. Reprint: Taibei: Shangwu yinshuguan, I991.

-(I982), Sui Tang Fojiao shigao 隋唐佛教史稿 (An Abstract of the History of Buddhism in Sui and Tang Dynasty). Beijing: Zhonghua shuju (reprint).

Tucci, Giuseppe (I929), 'Buddhist Logic before Dinnāga'. Journal of the Royal Asiatic Society: 45I-488 and 870-87I.

-(I930a), Pre-Dinnāga Buddhist Texts on Logic from Chinese Sources. Baroda: Baroda Oriental Institute.

- (1930b), The Nyāyamukha of Dinnāga. Leipzig: Harrassowitz.

Wagner, Rudolf G. (2003), Language, Ontology, and Political Philosophy in China. Albany: State University of New York Press.

Weinstein, Stanley (I973), 'Imperial Patronage in the Formation of T'ang Buddhism', in Wright, Arthur \& Twitchett, Dennis (eds.) Perspectives on the T'ang: 265-307. New Haven and London: Yale University Press.

Wright, Arthur and Twitchett, Dennis (eds.) (I973), Perspectives on the T'ang. New Haven and London: Yale University Press.

Wu Fenglong 吳鳳龍 (ed.) (I995), Da Tang xinyu 大唐新語 (New Talks from the Great Tang) by Liu Su. Wenbai duichao quanshi 文白對抄詮釋, Urumtchi: Xinjiang qingshaonian chubanshe.

Xu Dishan 许地山 (I928), ‘Chenna yiqian zhongguanpai yu yujiapai zhi yinming’ 陈那以 前 中观派与瑜伽派之因明 (Hetuvidyā logic of Mādhyamika and Yogācara before Dignāga) in: Xu Dishan (I994) ed.: Daojiao, Yinming ji qita. 道教因明及其 他 (Daoism, Hetuvidyā, and others): 5I-I65. Beijing: Zhongguo shehui kexue chubanshe.

Yan Lingfeng 嚴靈峰 (1983), Jingzi cong $z h u$ 經子叢著 (Collection of the Classics and Philosophers), vol. 6, Zhonghua congshu 中華叢書. Taibei: Guoli bianshi guan.

Zürcher, Erik (I959), The Buddhist Conquest of China. Leiden: Brill. 


\title{
2 Social Crises and Political Reform during the Jiaqing Reign of Qing China, 1796-1810s
}

\author{
Wensheng Wang
}

The Qianlong-Jiaqing transition ${ }^{\mathrm{I}}$ in the I790s was an eventful and a highly troubled period for the Qing dynasty (I644-I9II). It was marked by a riotous crescendo of widespread, often clustering upheavals - the South China piracy (I790s-I8IO), the Miao uprising (I795-97), and the White Lotus rebellion (I796-I805) - that engulfed much of the empire and shook the foundation of Manchu rule. This extraordinary conjunction of crises served as a foretaste of the escalating internal and external calamities that would convulse the late Qing state during the first Opium War (1839-42) and the Taiping rebellion (1850-64). It is also regarded as an important example of the worldwide phenomenon of 'state breakdown' at the turn of the nineteenth century (Goldstone I99I: 4-I2). ${ }^{2}$

Despite being beset by this cluster of upheavals, unlike his French royal counterpart, the Jiaqing emperor (r. 1796-1820) was not deposed. The Qing state rode out the challenges it faced from below and threats of war on its borders. What explains this outcome? There are many factors, to be sure, but the most important is the Jiaqing reform - a miscellany of moderate but decisive modifications of central institutions as well as innovations in policymaking. Focusing on only one part of this underrated political reform, this chapter takes an in-depth look at policy changes regarding the White Lotus sect, capital appeals and tribute gifts.

The dramatic combination of upheavals in the I79os had convinced Emperor Jiaqing that the late Qianlong state had failed to maintain a working balance with the increasingly expansive, complex and densely populated society. The young monarch gradually retreated from his father's fantasy of firmly controlling a society that was undergoing unprecedented transformation. Instead, he tried to create a new kind of order, which supported conservative but sustainable socio-political development. Jiaqing's primary task was to deal with the mounting crises by enacting new, ameliorative policies to alleviate social injustice as well as to relax aggressive state control over local society and the officialdom. He also tried to cut down excessive government expenditures. In 
a word, retreat, stabilization and rejuvenation became the main watchwords of Qing state policy and the dominant theme in political discourse during the Jiaqing reign.

\section{Toleration of the White Lotus sect}

The first important reform was to change stringent policy toward imperial China's most influential popular religious group - the White Lotus sect. The Jiaqing emperor and his officials came to realize that this sectarian tradition could never be extirpated as his father had wished, given its long history, extraordinary vitality and atomised nature (Overmyer 1976: 48). There was no single leader or congregation whose elimination would render the whole tradition incapable of carrying on. What the state could do was to undermine its popular base through a systematic program of pacification, the first step of which was to admit its existence.

The White Lotus sect, as a principal vehicle of Chinese popular religion, 'had its origins in the eleventh century as a form of lay piety, heir to a much older tradition of Pure Land Buddhism' (Mann and Kuhn I978: 136). It also incorporated elements of folk shamanism, Daoist magical techniques and Manichaean theologies (Overmyer 1976: 48). Ideologically syncretic and regionally diverse, the White Lotus sect had great vitality and widespread appeal among common people due to its simplified rituals, flexible invocations and popularized preaching. Its leadership in the Qing dynasty was 'a loosely-articulated network of sect-masters, whose positions had commonly been gained through hereditary transmission and whose interrelationships were cemented through teacher-disciple bonds' (Mann and Kuhn I978: 136). In addition, White Lotus sectarians had no distinguishable clothing or hairstyle recognized by the government (Overmyer I976: 48).

Scholars have long noted the extraordinary ability of the traditional Chinese state to regulate popular religious beliefs across the huge empire. The imperial government was so potent that it 'created a religion in its own image' by promoting a bureaucratic and Confucian version of heaven. As a result, the supernatural world of most popular religions is 'a detailed reflection of the social landscape of traditional China' (Wolf I978: I35, I75). This apparent parallel between the religious and secular bureaucracies entails that the pantheon of popular worship was not used to question or undermine the general system of political authority. Partly through the processes of 'standardization' (Watson I985), 'superscription' (Duara I988) or 'gentrification' (Guo 2003 2005), state-approved or local co-opted deities espoused a traditional morality of filial piety and loyalty to the government. These religious 
beliefs could take root and flourish precisely because they legitimated and reinforced prevailing socio-political relationships.

The White Lotus ideology, in striking contrast, could never serve as such a sort of mirror reflection or confirmation of the power hierarchies that existed in reality. Its perceived otherworld - 'True Empty Native Land' (zhen kong jia xiang, 真空家鄉) - was separated from or even opposed to this world; and the cycling of kalpas (jie, 劫, the Buddhist world ages) controlled by the supreme deity, the Eternal Venerable Mother (wu sheng lao mu, 無生老母), largely depended on the denial and destruction of the secular socio-political order. Much of this sectarian ideology was 'a reworking of borrowed symbols to deny the secular political hierarchy, to claim a higher legitimacy...' (Weller I982: 48I). Thus it could never be standardized, superscribed or gentrified as one part of the official religious system. Mainly for this reason, the name 'White Lotus teachings' (bai lian jiao, 白蓮教) became a convenient label used by the late imperial government to represent all varieties of heterodox popular religions (Ter Haar I992: 242-245). Consequently, during the Qing dynasty, many of the uprisings in North China were said to be motivated by the White Lotus sect (Naquin 1982: 337).

In addition to promoting violence, this rebellious sect also posed a grave challenge to the ideological foundation of imperial rule: Confucianism. Its scriptures, Precious Scrolls (bao juan, 寶卷), incorporated Confucius into the White Lotus pantheon, but ranked him only eighth among all the deities (PXXB I982: 22). Worse still, this sect developed totally different perceptions about family and filial piety from those of Confucian teachings. Connected by their devotion to the Eternal Venerable Mother, all White Lotus believers formed a big family in which their relationships were those of brothers and sisters. ${ }^{3}$ Furthermore, the three bonds (san gang, 三綱) between father and son, husband and wife, as well as monarch and officials, were discarded or even reversed. Only after entering the White Lotus sect could people fulfil the real filial piety: helping their parents achieve rebirth (PXXB I982: 22).

Both imperial officials and Confucian literati, not surprisingly, viewed this sect as a major threat to the orderly functioning of state, society and culture, so they made every effort to get rid of this danger. Hence there was persistent government suppression of the White Lotus religion, especially after the mid-fourteenth century when a massive, anti-dynastic rebellion inspired by this sect broke out and helped to destroy the alien Mongol Yuan rule. This trend became even more evident after the Ming-Qing dynastic transition. The new imperial edicts issued in 1646 and 1656 reaffirmed a hard line toward the White Lotus religion (Chu I967: 134).

The Qianlong emperor (r. I736-I795) certainly inherited this long tradition of unrelenting hostility and carried it to the extreme. As the 
soul-stealing scare of I768 suggests (Kuhn I990), ${ }^{4}$ the ambitious emperor had enacted overly aggressive policies against unauthorized religious activities across the empire. Consequently, 'religious rebellions crowded the records of every decade after the middle of the eighteenth century' (Yang I96r: I66). Particularly, the outbreak of the Wang Lun uprising (1774) in Shandong greatly heightened the danger of White Lotus sectarianism. Shortly thereafter, there was a sharp hardening of state policy toward this influential popular religious group (Gaustad I994: 3I). The Qianlong emperor called the White Lotus sect 'the most heterodox of the heterodoxies,' (xiejiao zhong zhi xiejiao, 邪教中之邪教, QDJPSS, I996: 54), vowing to extirpate it once and for all. He issued a harsh regulation that those who 'established heretical sects, taking pupils, deluding the masses and arousing chaos' should receive the same punishment as rebels: the practitioners were to be executed by slow slicing and the relatives of the chief culprits were to be killed or given away as slaves (Shi I999: II).

During the next two decades, however, White Lotus activities turned toward growing violence and better coordination, a trend, which continued through the early Jiaqing period. Under extreme pressure from government persecution, previous sporadic, peaceful sectarian activities developed into more militant and unified movements of a mass character. To cope with this deteriorating situation, Qianlong further strengthened his harsh policy in the closing decade of the eighteenth century and launched pre-emptive strikes against the White Lotus congregations across central China.

Then came the 1794-1795 investigations, which were one of the old emperor's 'last campaigns and the most ruthless' (Liu, 2004: 293). They were unprecedented both in terms of geographical scope and number of people prosecuted, thereby posing a most formidable threat to the sect and its members across central China. Several hundred sectarian leaders and lay believers were captured and executed in Hubei, Sichuan and Shaanxi, while many more were extorted and brutalized (Gaustad I994: 250). The yamen runners and clerks took this hard-hitting campaign as a license to enrich themselves by extorting the local people. They carried out a family-by-family search in some areas; those who failed to pay bribes were arrested as sectarians and tortured. The injustice and cruelty reached such proportions that it provoked widespread, intensifying popular discontent. To exploit this unstable situation, meanwhile, sectarian leaders built up a large following through preaching their hopeful teachings and instigating revolt whenever possible. Forced to pay or die, even those who were not insurgents opted to become rebels. With nowhere to hide, peaceful sectarians had to arm themselves and to rise up for self-preservation during this time of extraordinary hardship. 
Consequently, the aggressive prosecution campaign directly touched off the explosive flame of the White Lotus uprising. I argue that this rebellion emerged from a protective reaction (Perry I980: 3-4) against the predatory state intrusion and the perceived injustices in the local government. While spreading across various regions, this sectarian rebellion exploited the mounting tensions traversing local society and played a role similar to 'circuits for electric current', creating a large 'magnetic field' that assimilated diverse unstable elements and wove them into fairly coherent and massive protests (Kamachi I990: 352-353). ${ }^{5}$

One month into the uprising, on February 30, I796, Qianlong ordered that the White Lotus sect be banned forever (QZQWS vol. 2 I98I: 225; yong jin bai lian ming $m u$, 永禁白蓮名目). But this measure was of no avail. During the next three years, the growing tide of the uprising sent a strong signal to the Qing court that the old emperor's goal could never be achieved. Thus the succeeding Jiaqing emperor, upon taking full control of the government, drastically changed the state policy toward the White Lotus sect. In I80o, he issued a remarkable proclamation entitled 'On the Heretical Religious Sects' (xie jiao shuo, 邪教說):

It is self-evident that the White Lotus sect is different from the insurgent group. If there are one or two Buddhist monks and Daoist priests among the rebel forces, could we exterminate Buddhism and Daoism altogether? If there are one or two shengyuan members $^{6}$ who have joined the rebels, should we abolish the Civil Service Examination system? Hence, the White Lotus sectarians who have joined the insurgents should be executed according to imperial law. For those peaceful members who have not engaged in any rebellious activities, how could we allow their extermination? Considering this important distinction, it is apparent that what we have been dealing with in the past five years is a serious case of rebellion. It is not our goal to get rid of the heterodox sects (QDJPSS I996: 58; Chu I967: I68; emphasis added). ${ }^{7}$

In another edict of May 2I, I80o, the young emperor said that the two characters 'White Lotus' (bai lian, 白蓮), like other sectarian words, 'have been commonly used in Buddhist scriptures. How can we label it as heterodox?' (JQSYD 2000: vol. 5, 267) Later he went so far as to proclaim that: 'The genuine White Lotus sectarians are good people of our Great Qing' (QZQWS I98I: vol. 2, 33I). All of these documents fundamentally changed the meaning of being a White Lotus believer after forcing the Qing government, for the first time, to officially recognize the validity of this religion, at least in name. Jiaqing drew an important line between peaceful and rebellious White Lotus participants and laid down the policy of 'punishing the rebels, not the sectarians'. 
In these edicts, Jiaqing reached a reluctant compromise with the sect and relaxed state coercive sanctions against its practices. This practical and tolerant policy changed the long-established imperial law against the White Lotus group and set a brand-new tone for the official attitude toward this sectarian tradition in the late Qing. Moreover, the new approach relaxed the stringent limits set by the Qianlong emperor on acceptable forms of religious mobilization, and it thereby eased the mounting tensions between state and society.

In his classic study on the Empress of Heaven (tian hou, 天後), James Watson argues that the Qing state made every effort to dominate and enforce standardized forms of worship on the people (Watson I985). Jiaqing's new policy of tolerating the White Lotus sect suggests that it had become increasingly difficult to enforce this kind of standardization by the end of the eighteenth century. But my study supports Watson's argument that the primary concern of the government was political consequences rather than religious ideology. After the end of the rebellion, sectarians had more freedom to pursue their White Lotus beliefs. As a result, they embarked on an activist phase and mushroomed in different parts of the empire. In the Eight Trigrams uprising of I8I3, the White Lotus religion even infiltrated the eunuch circle and thereby seeped into the centre of imperial rule - the Forbidden City (Naquin 1976).

The two sectarian rebellions during the Jiaqing reign were usually taken as a clear sign of the decline of Qing ideological control. But what is more important, the young emperor understood this decay and made pragmatic policy changes to deal with the unwelcome reality. Even though the policy for easing up on attempts to suppress the White Lotus religion gave way to a new round of persecutions provoked by the I8I3 uprising, in the long run the Qing state began to take a rational, realistic approach toward the rebellious subculture of the heterodox sects and increasingly fought it with indoctrination rather than military force. Abandoning the fantasy of eradicating the White Lotus religion altogether, the imperial government tried to reduce the religion's appeal through an in-depth examination and criticism of sectarian scriptures and ideologies, especially at the local level.

A good case in point was the writing of 'A Detailed Refutation of Heterodoxy' (po xie xiang bian, 破邪詳辨) by Huang Yupian, a county magistrate in the Daoguang reign (I820-50). To save people from heresy, he collected a total of 68 White Lotus scriptures and criticized them one by one. ${ }^{8}$ The basic accusations in Huang's critique were irrationality, vulgarity and deviation from classical Confucian mythology (Overmyer 1976: 3I). Interestingly enough, Huang seldom used Confucianism itself to attack the White Lotus teachings. Instead the Buddhist and Daoist doctrines became his major weapons. In addition, some 
folk stories about ghosts and gods also loomed large in Huang's criticism. ${ }^{9}$

Thus ideological indoctrination replaced military suppression as the major state policy toward the White Lotus sect. Such an important policy change proved to be very effective in curbing the rebellious potential of the White Lotus sect and, slowly but surely, it declined after the Jiaqing reign. Most interestingly, the label of 'White Lotus' was seldom used openly, albeit the sect continued under the cover of numerous small groups using different names. Henceforth, no large-scale, longterm uprising was motivated and organized by this sectarian tradition in the late Qing. ${ }^{\mathrm{IO}}$

\section{Promotion of capital appeals}

Besides the toleration of the White Lotus sect, another important policy reform was to promote the tradition of capital appeals (jing kong 京控). Generally speaking, carrying a mishandled or an unadjudicated case to the capital was not a typical way of expressing local grievances in the Qing dynasty, because most people found this process arduous, difficult and risky. As Jonathan Ocko puts it, '... unless provincial justice was truly ineffective or distorted, people would not subject themselves to the fiscal and physical rigors of the journey to Beijing to lodge the appeal and then head back home for its adjudication by either the senior provincial officials or a specially commissioned imperial agent' (1988: 294).

Nonetheless, this kind of petition was an important last resort for ordinary people who had no other way to vent their grievances. Without resorting to such violent means as outright rebellion, local people relied on this peaceful avenue of remonstrance to have the central government somewhat remedy its own injustice. Seen from this perspective, in my opinion, capital appeals served as an effective institutional absorber or buffer of radical social protest in Qing China. As for the central government, dealing with those cases in general could enhance its knowledge of local situations as well as check the corruption and abuses of local officials.

Therefore the Jiaqing emperor had good reason to be greatly concerned about capital appeals. He believed that the White Lotus rebellion and South China piracy had a great deal to do with unsolved petitions and accumulated legal cases (JQQ JZ 2006: 4IO; JQSYD 2000: vol. 4, 24I). Thus, successful suppression campaigns required that the state fulfil its judicial responsibility by hearing people's unaddressed grievances and dealing out swift justice. The emperor specifically used the number of capital appeals as a standard to evaluate the perfor- 
mance of provincial officials (JQSYD 2000: vol. 9, 2I; vol. I2, I30), meting out quick punishment to bureaucrats accused of misbehavior. In so doing, Jiaqing turned capital appeals into a weapon at his disposal to better control the regular officialdom outside Beijing.

Before the start of his political reform in I799, however, the emperor did not closely supervise the scope and flow of petitions. As Jiaqing pointed out in an edict,

People from various provinces bring their charges to the offices of the censorate and the capital gendarmerie ${ }^{\text {II }}$. The responsible bureaucrats decide which cases warrant my attention, which can be remanded to their respective provinces for retrial, and which should be dismissed on the spot. These are the three ways of dealing with capital appeals. Charged with upholding those standards, the officials in both agencies can always make a decision at will (JQQ JZ 2006: 512, emphasis added).

Therefore, they could forestall unfavorable accusations, guard against any damaging upward flow of information and avoid scrutiny from the emperor. $^{\text {I2 }}$

After taking full control of the government in I799, Jiaqing decided to change this situation by stipulating that all capital appeals be accepted. As he continued to write in the aforementioned edict:

Now the avenue of communication has been broadened, it is hoped that all true information can reach my ears. If officials make bold to recklessly rebut or suppress any appeals against the provincial officials or other powerful bureaucrats, it will lead to more bribery and concealment which are matters of great consequence. From now on, the censorate and the capital gendarmerie cannot flatly reject any appeals from the province. Those serious cases should be sent to me immediately (JQQ JZ 2006: 512, emphasis added).

Some officials like Jia Yunsheng wanted to push the reform even further by proposing that no capital appeals, no matter how minor they were, could be returned to their respective provinces. This suggestion would have overburdened central government agencies with a wide range of cases, while provincial officials would have been left with little to do. It comes as no surprise that Jiaqing dismissed this idea as utterly impractical. He still thought that minor cases should be returned to their original provinces for retrial. But he ordered that, depending on the amount of appeals, a monthly or bimonthly summary report with clear explanation of each case should be sent to me. If I discover that a 
significant case is passed down to the provinces rather than being transmitted to me, responsible officials will be punished harshly (JQQ JZ 2006: 5I2).

To ensure their secrecy, the emperor also ordered that relevant officials should not open the sealed petitions before forwarding them to him. Consequently, a flood of requests flowed out of this important decision of promoting unrestricted capital appeals (Ocko I988: 296). According to the memorial of Jishan, vice censor-in-chief, the number of petitions reached its peak in 1799 and 1800 . This trend continued until I806 when there were still Io to 30 requests per month, in addition to other routine reports (JQJJC: 03-I489-087; JQSYD vol. II 2000: 96r).

Provincial leaders rarely shared the Jiaqing emperor's enthusiasm for fixing this long-standing problem. To those senior officials, capital appeals were always a troublesome thorn, which increased their work load, damaged their political reputation or even invited imperial scrutiny or punishment. Therefore, they often rejected local appeals without any investigation. For instance, Fujian peasant Zhang Kao submitted his petition to various provincial agencies as many as 62 times, but no one accepted it. Finally, he had no choice but to resort to a capital appeal (JQSYD vol. 5 2000: 292). Partly to protect their subordinates or themselves, some governors or governors-general did their best to stop people like Zhang from carrying their charges to Beijing (JQSYD vol. I2 2000: 499). When some of the appeals did reach the emperor's table and were later remanded back for further investigation, instead of processing those cases themselves, many provincial officials forwarded them to their original adjudicators in lower governments or simply dismissed them as baseless fabrication. Consequently, most passed-down appeals went unheeded or dragged on forever; and few of the accused were brought to justice (JQSYD vol. 8 2000: 45I).

The resulting severe judicial backlogs plagued the system of capital appeals (Ocko I988: 30I). On February 5, I800, for example, the emperor found out that most appeals in various prefectures of Zhili were never adjudicated; this amounted to 500 to 600 cases (JQSYD vol. 5 2000: 56). The problem was even more serious in Southeast China, the epicentre of the piracy disturbance. According to the investigation of Bai Ling, a newly-appointed Guangdong governor, such unsolved legal cases as lawsuits, land rights conflicts and homicides totaled as many as 2,000 in I806, the height of the maritime violence (JQJJC: 03-I496-00I). In his four-year term as Fujian governor, Wang Zhiyin accumulated more than 800 unconcluded cases. As for his successor Wen Chenghui, there were over 300 cases piled up during his sevenmonth service in that province (JQJJC: 03-I629-068). Under such hopeless circumstances, more and more people had no choice but to 
trek to Beijing again to lodge a second or third appeal. Some warlike appellants in coastal south China became so desperate that they joined the pirates to vent and rectify their grievances.

The Jiaqing emperor took great pains to pressure provincial officials to deal with the accumulated unsettled cases (qing ji an, 清積案) in a swift and just way. He issued a series of edicts to establish strict deadlines for the trial of different types of capital appeals. Specifically, imperially remanded cases were to be resolved by the governors or governors-general themselves within two months. As for those petitions returned by the central agencies, they were to be investigated and closed within four months. Otherwise, dilatory officials would face stern punishment (JQ JJC: 03-I629-068, 03-I527-058, 03-I537-048; JQSYD vol. 8 2000: 203 , vol. II 2000: 306,96 I). This strict regulation, once routinely enforced, proved to be effective in eliminating the serious legal backlogs accumulated during the late eighteenth century. The following chart is based on Vice Censor-in-chief Wang Ji's report to the Jiaqing emperor. It shows the number of unsolved cases in various provinces in I8IO, when the South China piracy was finally suppressed (JQ JJC: 03-I537-048):

Table 2.1 Number of Unsolved Capital Appeals in Various Provinces in 1810

\begin{tabular}{ll}
\hline Province & Unsolved Capital Appeals \\
\hline Shuntian Fu & 5 \\
Zhili & 16 \\
Shandong $^{13}$ & 68 \\
Shanxi & 1 \\
Henan & 1 \\
Jiangxi & 3 \\
Liangjiang & 15 \\
Jiangsu & 2 \\
Anhui & 4 \\
Zhejiang & 2 \\
Huguang & 5 \\
Liangguang & 2 \\
Guangxi & 1 \\
Shaangan & 2 \\
Sichuan & 2 \\
\hline
\end{tabular}

Source: JQJJC (Jiaqing junjichu lufu zouzhe, Jiaqing Grand Council Draft Memorials), December 21, 1810, 03-1537-048.

The low numbers of unsolved capital appeals in I8Io stood in a stark contrast to the large backlogs during the late Qianlong and early Jiaqing reigns. It is my argument that the extraordinary conjunction of the White Lotus rebellion and South China piracy played a crucial role in 
precipitating this dramatic change, which contributed to dampen social protest at the turn of the nineteenth century.

Capital appeals also helped to disclose and rectify widespread, local administrative malpractice, such as extortion and abuse of power, in the course of the suppression campaigns. As censors Chang Wen and $\mathrm{Lu}$ Yan pointed out, 80 to 90 per cent of the petitions were about overtaxation and plundering by county officials and yamen runners. This was corroborated by the major slogan of the White Lotus rebels: 'the officials forced the people to revolt' (JQJJC: 03-I629-024; JQSYD vol. I3 2000: 702; guan bi min fan, 官逼民反). For instance, Sichuan peasant Wu Tianxiang from Dingyuan County went to the capital gendarmerie office to appeal the magistrate's extortion of local people on the pretext of preparing for military campaigns. Liu Renlong, magistrate of Naxi County in Sichuan, was cashiered due to his exploitation disclosed in peasant Ding Keyu's capital appeal in June I799. So were three other magistrates in Lidu, Jiangyou and Wenjiang counties (JQJJC: 03-I7IOo37). Wang Weiping, magistrate of Shishou County in Hubei, was also similarly punished (JQ JJC: 03-I477-088, 03-I477-090).

In addition, capital appeals provided opportunities for those who wished to advance themselves by offering services during the time of crises. For instance, in October I799, the general commandant of the capital gendarmerie Buyandalai forwarded four sealed petitions to the Jiaqing emperor. They were sent by Sichuan gongsheng ${ }^{\mathrm{I}}$ Ren Siyue, dismissed yamen runner Xiao Rui from Guangdong, Wang Zhengzhi from Jiangsu and shengyuan Yang Shangqiong from Hunan. With firsthand experience of the upheavals, all of them volunteered to serve on the battlefield without salary (JQ JJC: 03-I477-083).

Other petitioners of various backgrounds were also eager to present their bottom-up solutions to the escalating disturbance. These people were from all over the country, especially from the crisis-torn areas. To give a few examples, Zhili jiansheng ${ }^{15}$ Zhu Shouhai came up with I3 strategies to deal with pressing social ills (JQ JJC: 03-I500-039). Jiangsu peasant Pang Dachun focused on I4 urgent matters in his petition (JQ JJC: 03-2497-024). Jiangxi jiansheng Kuang Yuanli travelled to Beijing at the age of 70 to propose five suggestions for subduing the South China pirates (JQJJC: 03-I600-006, 03-I600-008). Fujian shengyuan Wu Zhi and Shuntian yamen clerk Yu Ruiying also voiced their opinions on the maritime violence through the delivery of sealed letters (JQ JJC: 03-2I73-059, 2943). Most interestingly, even a Buddhist monk, Huiming, presented a message, but with a threatening and sermonizing tone. If the responsible official brought his letter to imperial attention, the monk claimed, he would be blessed by the Buddha; otherwise, great disasters would befall him (JQ JJC: 03-2497-037). 
This enthusiastic (and sometimes humorous) overflow of grassroots wisdom and intellectual mobilization was facilitated by Jiaqing's 'broadening of the communication avenues' after I799. The new emperor rewarded most of those petitioners with imperial gifts or honorary titles. He also took their suggestions seriously, some of which were later applied to the suppression campaigns. Therefore, the soaring social crises and capital appeals not only provided golden opportunities for those local people to enjoy some sort of upward social mobility, but also indirectly influenced policymaking and personnel selection at the high levels of imperial bureaucracy. In other words, capital appeals became an important tool to broaden political participation during the time of crises. Elizabeth Perry defines political development as 'a process whereby different social elements gain an institutionalized voice for articulating their political interests and demands' (I997: 25I). In this sense, social crisis could serve as a catalyst for change and as a carrier of political progress in pre-modern China.

\section{Discontinuation of sending tribute gifts}

Apart from promoting the practice of capital appeals, the Jiaqing emperor also ended the time-honored practice of sending tribute gifts (JQDHL: 9I; jin gong, 進貢). On numerous occasions every year, especially on imperial birthdays and major holidays, high-ranking officials throughout the country, particularly those in border provinces, had been obliged to present all kinds of lavish gifts as tribute to the throne. During his long reign, Qianlong issued at least two edicts to nominally prohibit this tradition. But, in effect, the flamboyant emperor encouraged this practice through his own proverbial extravagance. For instance, one of the main reasons that Qianlong indulged in pleasure trips to the South was to collect gifts for himself and his mother (Kahn I971: 9I-95).

Some scholars tend to neglect the overall significance of this tradition and its pernicious influence. Nancy Park, however, contends that its damaging impact should not be overlooked. Specifically, the economic burden of providing tribute gifts was directly related to the increasing official corruption during the Qianlong reign. 'Most provincial officials spent vast amounts of time and money preparing unique and costly tribute gifts in an attempt to insinuate themselves into the emperor's good graces' (Park 2002: I72). Since their salary was always insufficient to fund their purchases, bureaucrats inevitably resorted to bribery, de facto extortion, or other forms of corruption. As Hong Liangji, a contemporary Hanlin Academician, stated, 'all of this money is extracted from chou and hsien officials, who in turn get it from the 
people' (Mann I972: I76). The insatiable imperial demand for tribute gifts thus contributed to Qing China's intensifying crisis in the late eighteenth century.

David Nivison argued specifically that Qianlong's favorite minister Heshen was the fountainhead of this problem. 'Vast sums were embezzled by officials under constant pressure to secure themselves by gifts and bribes to Ho-shen and his immediate subordinates. Everywhere local treasuries were depleted. The groaning people, goaded to desperation by the rapacity to which their magistrates were driven, turned to revolt' (Nivison I966: 209). Hence the problems of tribute gifts, official corruption and local extortion closely interacted with each other, precipitating the clustering crises throughout the empire. As one of the greatest scourges of the Qing dynasty, they partly contributed to the disruption of the balanced tension between the state and society (as well as emperor/officialdom interactions) at the turn of the nineteenth century.

To ease this heightened conflict, Jiaqing issued the following edict to denounce the deep-seated problem: 'Provincial officials send tribute gifts in the name of serving the emperor, but in fact this is just an excuse for them to fatten and empower themselves. They use declined gifts to bribe high-ranking bureaucrats, some of which are drained off to their own private coffers. Furthermore, lower officials find themselves competing with each other in flattering their senior officials with valuable gifts, even if this means squeezing local people. So sending tribute gifts is the worst evil to politics, which I understand very well' (JQSYD vol. 4 2000: 2I-22; JQDHL: 68).

Only twelve days after asserting his personal power, on January I5, I799, the new emperor promised in an edict that he would never accept any gifts from provincial officials other than simple local products like tea and oranges for daily use (JQSYD vol. I2 2000: 924; yong $d u$ gong xian, 永杜貢獻). In striking contrast to his father, who had an extravagant lifestyle, Jiaqing fostered an image of himself as a thrifty emperor. He shared his grandfather Yongzheng's distaste for conspicuous consumption, finding luxury and waste abhorrent and reprehensible. The new emperor said: 'In my eyes, so-called treasures like antiques, not to be eaten or worn, are no better than shit (fen tu, 糞土)' (JQGZZP: 04-0I-06-0005-002; JQSYD vol. 4 2000: 22; JQSL: 427).

In stark contrast to his father, Jiaqing extolled frugality through personal example and official policy. Rumors had it that his imperial robes were repeatedly patched. He also cancelled all repair work on palace buildings to curtail their soaring upkeep cost. No gifts of congratulation were allowed at the birth of any imperial sons or grandsons (JQSYD 2000: vol.I3, 29I). The new emperor, moreover, 'ended the tradition of extravagant southern tours that had been a hallmark of his 
father's rule' (Mann and Kuhn I978: II8). He knew that, as Qianlong himself had admitted toward the end of his reign, this sort of imperial tour would inevitably burden the people no matter how much he might admonish officials against abuses.

\section{Further thought: A re-evaluation of the Jiaqing reform}

As this chapter describes, the shock of the clustering crises during the Qianlong-Jiaqing transition forced a reconsideration of state policy, including tolerating the White Lotus sect, encouraging capital appeals and prohibiting tribute gifts. Taken together, all of these changes seem to suggest that the temper of the Jiaqing reign was one of increasing stringency and diminishing state power, both of which have often been taken as clear signs of incorrigible dynastic decline.

Therefore existing studies tend to downplay the Jiaqing reform as another case of unsuccessful piecemeal modification, overlooking its impact on late Qing history. They argue that due to his personal timidity or to systematic inertia, Jiaqing made little meaningful attempt to deal with acute problems inherent in the socio-political system (Mann and Kuhn I978: II6-II9). Beatrice Bartlett, for instance, even contends that the term 'Jiaqing reform' is a misnomer because 'a new, inexperienced monarch would hardly have possessed sufficient power, let alone acumen, to carry out reform on his own' (I99I: 24I).

Nonetheless, it is the central argument of this article that the young emperor and his officials, through their pragmatic efforts of political retreat embodied in the Jiaqing reform, pulled Qing empire-building away from a vicious cycle of excessive ambition that bred resistance back onto a sustainable track of political development. In responding to the White Lotus rebellion and South China piracy, they recreated more workable bases for the state-society and emperor-bureaucracy relationships through policy adaptation (and institution modification). All of these endeavors exercised a pivotal influence on the sustainable development of Qing state making and social mobilization before the full rise of Western assault in the mid-nineteenth century.

What is 'sustainable development?' To borrow a definition from the Brundtland Report of the World Commission on the Environment and Development, it refers to 'meet(ing) the needs of the present without compromising the ability of future generations to meet their own needs' (Willis, 2006). ${ }^{16}$ So the concept is not as much about the current situation as it is about how the situation will impact the future. When most people think about the issue of sustainability, economic growth and ecological stability invariably come to mind. However, I 
think this category also has a political component, which can be employed to measure the process of state making.

Unlike its counterpart in economic and environment changes, political sustainability is less about humans' relationship to their supporting natural environment and resource bases. Instead, in my view, it refers to creating and maintaining viable, renewable and dynamically balanced relationships among the socio-political actors or agencies at various levels. This general concept means organizing individuals and groups bound by some common purpose to achieve objectives, as well as mobilizing collective actions in the face of complex conflict and making cost-efficient negotiation or allocation. Most importantly, sustainable political development is also about coordinated and compatible growth among the various arenas or sub-mechanisms of state making. The essence of political sustainability, simply put, is a tense yet dynamically balanced relationship between the state and society.

Judging from this criterion, without being able to quantify precisely, I assert that a major bottleneck to sustainable political development appeared in Qing Empire during the Qianlong-Jiaqing transition. This period witnessed an overloaded and ungovernable Chinese state, which had become 'a system working near the limit of what was possible by pre-modern means' (Elvin I973: 309). The cost of political operation, transaction and control ${ }^{17}$ had reached unacceptable heights due to the Qianlong emperor's aggressive empire-building and highly interventionist policies, sweeping social transformation, as well as bureaucratic struggles. All of these nullified the structures and cultures, which facilitated obedience and compliant behavior from the officialdom and the populace.

As an unmistakable sign of this unsustainable development, military campaigns against internal rebellions were becoming more frequent, more serious and exceedingly costly toward the end of the eighteenth century. The suppression campaign against the White Lotus rebels, in particular, was the most costly military operation in which the dynasty had ever engaged. According to the estimates of the Board of Revenue, the first three years of the campaign cost almost 100,000,000 silver taels. This amounted to about two thirds of the total expense for the 'Ten Great Military Campaigns' (QZQWS vol. 2 I98I: 265; shi quan wu gong, 十全武功) ${ }^{\mathrm{I} 8}$ during the long Qianlong reign, and half of the total expense of the decade-long suppression of the sectarian rebels. Moreover, half of the funds were used for illegitimate purposes (JQJJC: 03I708-069).

From this we can see that the survival of the Qing state became increasingly contingent on the capacity of the central government to use material and instrumental rewards as well as on relaxed control to enforce acquiescence from its officials with state goals. Worse still, the 
Qianlong emperor used his power and enforced policies in a way that compromised, rather than promoted, a sustainable, constructive relationship between the throne and his bureaucracy. Consequently, established socio-political relations and institutions came under increasing pressure as the monarch and the state became more and more aggressive.

Instead of creating an increasingly capable state in the closing decades of the eighteenth century, overly ambitious political practices seemed to undermine the administrative capacities and resource bases of the state, which in turn necessitated even more unpopular policies. This had initiated a vicious cycle of predatory state making and mounting social protests which shaped the character of the late Qianlong reign: a chain reaction of increasingly unbalanced tension between state and society. And it was this impasse that prompted the dramatic combination of crises during the Qianlong-Jiaqing transition.

The Jiaqing emperor had the bad luck to face more daunting challenges with fewer options and less room to maneuver than his father. This strained situation suggests that the Qing state had entered into a period when sustainable political development became extremely difficult if not impossible. Fully aware of his unique historical challenge and daunting mission, the realistic emperor set his mind to preserving the dynasty (shen shou pi ji, 慎守丕基, JQSYD 2000: vol. I2, I49) through a proactive state retreat instead of a path-dependent aggressive expansion. Thanks to his successful policy reform and crisis-management, Jiaqing relaxed the intolerable pressure on the empire, eased the mounting tensions within it and adjusted the state's political commitments to make its functioning compatible with shifting structural challenges and capacities.

Once we take the pragmatic state retreat embodied in the Jiaqing reform seriously, we see that it laid the foundation for the long-term successful strategies of late Qing state making. This crucial political adjustment helped a hard-pressed yet tenacious empire survive an extraordinary series of internal calamities and external assaults in the midnineteenth century. The White Lotus rebellion and South China piracy, viewed in this light, also became an opportunity, which the Jiaqing emperor used to undertake initiatives that had durable constructive benefits for the Chinese state and society.

\section{Notes}

I After sixty years on the throne, on January I, I796, the 85-year-old Qianlong carried out his promise to step down and became the 'Supreme Abdicated Monarch'. His fifteenth son Yongyan ascended the throne as the fifth emperor of the Qing, with the 
reign title Jiaqing. However, Qianlong still retained substantive power after his abdication and relied on his imperial favorite Heshen to rule. As for the new emperor, he became a figurehead who was allowed to reign but not to govern. Jiaqing did not assume full power until he executed Heshen I5 days after Qianlong's death on January 3, I799.

2 The concept of 'state breakdown' is put forth by Jack Goldstone. It refers to a particular conjunction of events, but not quite a revolution, which 'involved the collapse of the central authority's ability to dominate in a confrontation with other politically powerful actors, rather than the breakdown of all political institutions' (Goldstone I99I: 4-5).

3 The Eternal Mother appeared in the White Lotus scriptures during the mid-Ming. As the supreme goddess and ancestor of humans, she was said to save her believers by sending different Buddhas to the world when the new kalpa came. Only in this way, could her children survive the calamities and live happily in the 'True Empty Native Land'.

4 In his book Soulstealers, Philip Kuhn describes a series of local events that occurred in 1768 , which began with rumors of soulstealing by queue-cutting spreading through east-central China. According to contemporary popular culture, by cutting other people's queue, one could steal his soul and make use of it for malicious purposes. The person with his queue cut would get sick or even die. From the government's perspective, queue cutting was taken as a rebellious act and symbolic rejection of Manchu hegemony. Motivated by the dual fear of sedition and ethnic assimilation, the Qianlong emperor intentionally exaggerated this ordinary, local sorcery scare as a 'political crime'. In response, he launched a massive political campaign to inject his own arbitrary power and to avoid becoming bureaucratized himself.

5 Both terms were first used by Japanese historians Ueda Makoto and Atsushi Shigeta. See Noriko Kamachi's article.

6 Shengyuan was the lowest degree and rank in the Civil Service Examination system in imperial China.

7 I consulted and modified Richard Chu's translation.

8 This was the first time that the Qing government tried to criticize the White Lotus sect in terms of its own scriptures.

9 The most influential story was 'Record of Infernal Nemesis to the Heterodoxies' (xie jiao yin bao lu, 邪教陰報錄). In this story, an executed rebel - Zhong Fa - told his own grim experience about how he suffered from macabre tortures with other rebels in hell. The highest deity, Eternal Mother, was portrayed as a mule in heaven that transmigrated to this world as a female. Because of disseminating heterodoxies, she was killed by the supreme god in the end.

Io Joseph Esherick discredits the once common claim that the Boxer Rebellion of I900 had a White Lotus link (Esherick, I987).

II "Gendarmerie" here refers to a Qing institution, also called Capital Infantry Brigade or garrison, which was given responsibility of enforcing law and order in Beijing, including accepting capital appeals along with the Office of Censorate.

I2 It is not unreasonable to infer that Heshen, as long-time General Commandant of the Capital Gendarmerie, had played an important role in restraining capital appeals during the late Qianlong reign (JQQ JZ 2006: 364 ).

I3 In comparison with other provinces, Shandong and Zhili had far more unsolved cases in I8Io, which might partly explain the mobilization and outbreak of the Eight Trigram uprising in both areas three years later.

I4 Gongsheng refers to those shengyuan who were selected as 'tribute student of the imperial academy'. Many people could become gongsheng or jiansheng through direct donations or other contributions. 
I5 Like gongsheng, jiansheng means 'imperial college student'. The status of jiansheng, in general, was also available for purchase.

I6 The Brundtland Commission was also called the World Commission on the Environment and Development. It was established in 1982 by the Secretary-General of the UN to study the world's environmental problems. This commission came up with this definition of sustainable development, which emphasizes meeting needs, not just now, but in the future as well.

I7 Political operation, transaction and control consist of the processes that seek for optimal alignment in the distribution of wealth, power and prestige among various actors and agencies. Therefore most political problems, traditional or modern, are concerned with the distributive question of achieving and maintaining a dynamic equilibrium between socio-political forces.

I8 Qianlong describes his 'Ten Great Military Campaigns' in the following edict of I798: 'Since my ascension to power, I pacified Zunghar twice (1755-59), suppressed the Muslims (I765, I780s), and defeated the two Jinchuan (I747-49, I77I-76), recovered Taiwan (I787-88), mollified Burma (I766-70) and Annam (I788-89), and made the Kuorke surrender twice (1790-92)...'

\section{References}

\section{Primary sources}

JQDHL (1963), Jiaqing Dong Hua Lu (Donghua History of the Jiaqing Reign). Taibei: Wenhai chubanshe.

JQGZZP Jiaqing gongzhong zhupi zouzhe (Imperially Rescripted Palace Memorials, Jiaqing Emperor). The First Historical Archives of China, Beijing, P.R.C.

JQJJC Junjichu lufu zouzhe (Grand Council Draft Memorials, Jiaqing Emperor). The First Historical Archives of China, Beijing, P.R.C.

JQQ JZ (2006), Jiaqing Qi Ju Zhu (Court Diary of Imperial Actions and Speeches, Jiaqing Emperor). Guilin: Guangxi shifan daxue chubanshe.

JQSL (1986), Jiaqing shilu, (Veritable Records of the Jiaqing Emperor). Beijing: Zhonghua shuju.

JQSYD (2000), Jiaqing Shang Yu Dang (Imperial Edicts of the Jiaqing reign). Guilin: Guangxi shifan daxue chubanshe.

PXXB Huang Yupian (1982), Po Xie Xiang Bian (A Detailed Refutation of Heterodoxy), in Qingshi ziliao, vol. 3. Beijing: Zhonghua shuju chubanshe.

QDJPSS Qinggui (ed.) (1996), Qin Ding Jiao Ping Shan Sheng Xie Fei Fang Lue (Imperially Authorized Account of the Pacification of the Three Province Sect Rebels), vol. 39I. Shanghai: Shanghai guji chubanshe.

QZQWS Zhongguo shehui kexue yuan lishi yanjiusuo Qingshi shi (eds.) (I98I), Qing zhongqi wu sheng bailian jiao qiyi ziliao (Materials on the Five-Province White Lotus Uprising of the Mid-Qing), 5 vol. Nanjing: Jiangsu renmin chubanshe.

\section{Secondary sources}

Bartlett, Beatrice S. (199I), Monarchs and Ministers: The Grand Council in Mid-Ch'ing China, I723-I820. Berkeley: University of California.

Chu, Richard (1967), 'An Introductory Study of the White Lotus Sect in Chinese History: With Special Reference to Peasant Movements'. Ph.D. diss., Columbia University.

Duara, Prasenjit (I988), 'Superscribing Symbols: The Myth of Guandi, Chinese God of War'. The Journal of Asian Studies, 47 (4) 778-795. 
Elvin, Mark (I973), The Pattern of the Chinese Past: A Social and Economic Interpretation. Stanford: Stanford University Press.

Esherick, Joseph (1987), The Origins of the Boxer Uprising. Berkeley: University of California Press.

Gaustad, Blaine (I994), 'Religious Sectarianism and the State in Mid Qing China: Background to the White Lotus Uprising of I796-I804'. Ph.D. diss., University of California Berkeley.

Goldstone, Jack (I99I), Revolution and Rebellion in the Early Modern World. Berkeley: University of California Press.

Guo, Qitao (2003), Exorcism and Money: the Symbolic World of the Five-Fury Spirits in Late Imperial China. Berkeley: Institute of East Asian Studies, University of California, Berkeley/ Center for Chinese Studies.

- (2005), Ritual Opera and Mercantile Lineage: The Confucian Transformation of Popular Culture in Late Imperial Huizhou. Stanford: Stanford University Press.

Kahn, Harold (I97I), Monarchy in the Emperor's Eyes: Image and Reality in the Ch'ien-lung Reign. Cambridge: Harvard University Press.

Kamachi, Noriko (I990), 'Feudalism or Absolute Monarchism: Japanese Discourse on the Nature of State and Society in Late Imperial China'. Modern China I6 (3): 330-370.

Kuhn, Philip A (I990), Soulstealers: The Chinese Sorcery Scare of 1768. Cambridge: Harvard University Press.

Liu, Kwang-Ching (2004), 'Religion and Politics in the White Lotus Rebellion of I796 in Hubei,' in Liu, Kwang-Ching and Shek, Richard (eds.), Heterodoxy in Late Imperial China: 28I-322. Honolulu: University of Hawai'i Press.

Mann, Susan (I972), 'Hung Liang-Chi (I746-I809): The Perception and Articulation of Political Problems in Late Eighteenth Century China’. Ph.D. diss., Stanford University.

— and Kuhn, Philip A. (I978), 'Dynastic Decline and the Roots of Rebellion', in John K. Fairbank (ed.), The Cambridge History of China, vol. Io, IO7-I62. London and New York: Cambridge University Press.

Naquin, Susan (1976), Millenarian Rebellion in China: The Eight Trigrams Uprising of 1813. New Haven: Yale University Press.

-(I982), 'Connections between Rebellions: Sect Family Networks in Qing China'. Modern China, 8 (3): 337-360.

Nivison, David S. (I966), 'Hoshen and His Accusers: Ideology and Political Behavior in the Eighteenth Century', in David S. Nivison and Arthur F. Wright (eds.), Confucianism in Action: 209-243. Stanford: Stanford University Press.

Ocko, Jonathan K. (I988), 'I'll Take it all the Way to Beijing: Capital Appeals in the Qing'. Journal of Asian Studies 47 (2): 29I-3I5.

Overmyer, Daniel (I976), Folk Buddhist Religion: Dissenting Sects in Late Traditional China. Cambridge: Harvard University Press.

Park, Nancy (2002), 'Managing Corruption in Code and Practice: The Prosecution of Jiang Zhou and Qian Du', in Robert J. Antony and Jane Kate Leonard (eds.), Dragons, Tigers, and Dogs: Qing Crisis Management and the Boundaries of State Power in Late Imperial China: I55-I82. Ithaca: Cornell University Press.

Perry, Elizabeth J. (I980), Rebels and Revolutionaries in North China, 1845-1945. Stanford: Stanford University Press.

- (I997), 'Popular Protest and Political Progress in Modern China', in Fredrick Wakeman and Wang Xi (eds.), China's Quest for Modernization: A Historical Perspective: 250-266. Berkeley: Institute of East Asian Studies.

Shi, Yun (I999), 'A Sectarian Family: Cultivating Social Space in Late Imperial China'. Ph.D. diss., University of California, Berkeley.

Ter Haar, B. J. (I999), The White Lotus Teachings in Chinese Religious History. Honolulu: University of Hawai'i Press. 
Watson, James (1985), 'Standardizing the Gods: the Promotion of Tianhou along the South China Coast, 960-1960', in David Johnson, Andrew Nathan, and Evelyn Rawski (eds.), Popular Culture in Late Imperial China: 292-324. Berkeley: University of California Press.

Weller, Robert P. (1994), Resistance, Chaos, and Control in China: Taiping Rebels, Taiwanese Ghosts, and Tiananmen. Seattle: University of Washington Press.

-(1982), 'Sectarian Religion and Political Action in China'. Modern China, 8 (4): 463-483.

Willis, Michael (2006), 'Sustainability: The Issue of our Age, and a Concern for Local Government'. Public Management 88 (7): 8-12.

Wolf, Arthur (1978), 'Gods, Ghosts, and Ancestors', in Arthur Wolf (ed.), Studies in Chinese Society, I3I-I82. Stanford: Stanford University Press.

Yang, Ching Kun (196I), Religion in Chinese Society. Berkeley: University of California Press. 


\title{
3 'China' on Display at the Chicago World's Fair of 1893: \\ Faces of Modernization in the Contact Zone
}

\author{
Yuki Ooi
}

\section{Introduction}

At the end of the nineteenth century and the beginning of the twentieth century, many changes were taking place in China. At that time, the government of the Qing dynasty was struggling to modernise the nation in order to survive, while Chinese people on American soil were also struggling with modernisation. Chinese who lived in the United States maintained transnational relations with their homeland and cared about this relationship, but at the same time they had begun to settle into American society. Because of their experiences living in a Western country, it can be assumed that their idea of modernization was influenced by the United States and thus was somewhat different from that of those Chinese who remained in their homeland.

This chapter will focus on what this modernization meant, not to people in China, but to the overseas Chinese living in the United States. There are two issues we shall explore in this chapter. One is how the new identity of Chinese residents in the US as Chinese became evident in the United States as they were simultaneously becoming American. 'Chinese' here means a national identity in the context of China and an ethnic identity in the context of the United States. It was not until the late nineteenth century that an awareness of having a 'Chinese' identity began to emerge among the Chinese living in America. Before this period, other types of identity such as clan or birthplace were stronger among Chinese in the US, as will be discussed later in this paper. In addition, this chapter will also examine what Chinese immigrants in the US thought about modernization while being influenced by American modernization. As a case in point, I will examine the World's Fair held in Chicago in I893, and hence focus on Chinese residents in the Chicago area, because the Fair, which was planned as a celebration of modernization, created and served as a contact zone 
where American and Chinese ways of modernity encountered each other. In order to explore these two points fully, the chapter begins by giving some background on the situation in China at the end of the nineteenth century and the beginning of the twentieth century and how this situation affected the modernization and the national identity of Chinese in China. After that, the focus will turn to Chinese immigrants in America and the Chicago World's Fair.

\section{China at the turn of the nineteenth century}

At the turn of the century, the Chinese empire was weakened by internal wars such as the Taiping Rebellion (1851-1864) and the Boxer Uprising (I898-1900) and the wars with Britain, France and Japan in the mid- to late-nineteenth century. The Chinese empire was on the verge of being divided into smaller parts by imperialist forces, such as Britain, Japan, France, Russia, Germany, Austria, Italy and the United States. The Boxer Uprising turned out to be the final blow delivered to the Qing government. The Boxer rebels, many of whom were peasants, declared themselves anti-foreign and anti-imperialist. With this excuse, they assaulted and murdered foreigners and Chinese Christians living in Beijing. The Empress Dowager proved ineffective in protecting the people against the insurgency. Realising this, an International Relief Force of eight countries was organized and besieged the capital to protect their own nationals. Fearing them and the possibility of dismemberment of the country, the Empress Dowager finally conceded that the Qing dynasty could not keep its soil closed to foreign countries and maintain the status quo, which meant that the country required reforms in all areas, but in particular in education, the military and the constitution. By modernizing these national institutions, the government sought to avoid being colonized.

It was during this period that the national border was clearly determined. In addition, the people started to identify themselves nationally as Chinese, rather than identifying themselves locally (Yoshizawa 2003). As for the national border, the Qing government regarded borders as expandable; with the emperor at the center of the empire, territory could expand depending on how virtuous in a Confucian sense the emperor was. That is, the more virtuous he became the greater the areas that his domain could govern. In this belief system, which originated from Confucianism, the Qing government formed loosely connected networks with its surrounding nations through the practice of accepting tribute. Any group, in principle, could join the network as long as they appreciated the emperor's virtue and paid tribute. In other words, the center was established where the Emperor resided, whereas 
the periphery of the empire was ambiguous, because the empire constituted the aforementioned open-ended networks. At the turn of the century, however, territorial skirmishes and Japan's attempts to invade Korea and Taiwan forced the government to determine a national border (Mogi 1994). Now China had to claim its own border, and this meant the periphery could not be ambiguous any longer. The determination of its national border was a significant change in China at this time of modernization.

In addition to this development related to the physical awareness of China, the mental awareness, the consciousness of being 'Chinese' or the collective identity of being 'Chinese', emerged around this time, too (Yoshizawa 2003). This raises the question, why did people in China not think of themselves as Chinese before? Earlier studies have pointed out two reasons. First, it has been argued that, traditionally, people identified themselves with the place from which they originated. This strong connection to the local level even applied to emigrants living in other countries; they organized themselves for mutual help along the lines of where they came from or according to their clan. The second reason why they did not earlier identify themselves as Chinese was that the Qing government did not establish the nationality law until ı9ı0. This nationality law literally gave nationality to the Chinese people. Before this, there was no official nationality. What accentuated the identity of being Chinese at that time was a nationwide boycott movement of American products in 1905, which first developed in Guangdong Province and spread to other areas such as Shanghai and Tianjin (Kikuchi 2005; Yoshizawa 2003). Guangdong was the original home of many of the Chinese who emigrated to the United States in the nineteenth century; more than 90 per cent of them came from the Pearl River Delta area. The boycott was mobilized as a protest against discrimination in the United States against Chinese immigrants, which I will discuss in more detail later. In order to organize this widespread movement, people gradually developed their new identity beyond region into a trans-regional consciousness, namely, the identity of being Chinese. This transformation was significant, since in China emigrants who had left the country to go abroad were deemed 'traitors', who had discarded their motherland (Yen 1985). In the course of the boycott, however, those who joined it regarded the emigrants as their fellow countrymen. In this way, the national identity emerged in addition to the local identity in China.

These two developments, the emergence of a clear-cut national border and the establishment of a national identity, constituted necessary steps in becoming a modern nation-state, as Benedict Anderson discussed in his book, The Imagined Community (I99I). Therefore, it can be said that the Qing dynasty attempted to mold itself into a modern 
nation-state while actually carrying out reforms of the pre-existing state structure.

\section{World's Columbian Exposition of 1893, Chicago}

Modernization was an issue not only for the Chinese in China, but also for the Chinese abroad. In I893, Chicago, a city in the midwestern United States, welcomed approximately 27.5 million visitors to the World's Fair. It was the third such fair held in America, coming after those that took place in New York (I853) and Philadelphia (1876). The Fair was designed to celebrate the 40oth anniversary of the 'discovery of the New World' by Columbus, as well as the progress and modernization of America since that time. Thus, the Fair was called the 'World's Columbian Exposition.' In the initial preparation stage, four cities had launched a bid to host the Fair; in addition to Chicago, New York, Washington DC and St. Louis in Missouri vied to host the exposition. To win this competition, Chicagoans began to organize themselves as early as I889. Among the four candidate cities, many people expected New York to win. However, thanks to an internal feud among New York statesmen, Chicago won the bid at the US Congress in I890. There was yet another reason why the city was chosen. The Chicago Tribune, a local newspaper, pointed out the insularity and provincialism of New York, which failed to recognize and did not pay enough attention to the fact that there were cities and other Americans living in the West beyond the Allegheny Mountains (25 February I890). Therefore, the Tribune expected that choosing Chicago would make Eastern states recognize that cities and people in the midwestern or the western US were also cultivated and modernized (Lederer II 1972; Parmet I972).

In I893, after more than two years of preparation, the Fair finally opened on May Ist, and lasted until October 23rd. The venue was divided into two parts, the White City and the Midway Plaisance. The White City was designed to show American progress and how civilized the nation had become. For this purpose, the newest technologies and sciences were exhibited in buildings for 'Manufactures and Liberal Arts', 'Machinery', and 'Agriculture'. Several of these exhibition buildings were advertised as being huge. For example, the Manufactures and Liberal Arts Building was the largest building in the world then, three times bigger than St. Peter's Basilica in Rome. In addition, the architects involved designed the buildings to be white, emulating those of ancient Rome. They believed that the Fair should represent the pure ideal of this ancient civilization (Doenecke I973). In sum, visitors were 
to find at the venue of the White City an eclecticism of ancient and new civilizations.

The Midway Plaisance was conceptualized differently. This exhibition ground was planned by the Fair's Department of Ethnology and Archaeology, headed by Professor Frederic Ward Putnam of Harvard University. He decided that the Midway exhibits had to have anthropological value, which was new and thus entertaining to the American people. Among the Midway exhibits were, for example, villages of the Javanese, Native Americans, and Samoan and Dahomeyan cultures. Japanese and Chinese exhibits were also housed there. In other words, the Midway was a living museum of various people, which entertained visitors from all over the world. Interestingly, exhibits such as the Irish Village, Japanese Bazaar and German Village were placed closer to the White City, whereas the space allotted to China was far from the civilized precincts of the White City. It was reported that the exhibits of the Midway were organized along an evolutionary line (Chicago Tribune, I November I893), proceeding from least to most civilized; the closer the participant countries' exhibition spot to the White City, the more civilized they were regarded by the American public and the expo organizers. In sum, the Midway Plaisance represented 'barbarian' cultures, while the White City embodied 'civilization' (Rydell i984; Bederman I996). Therefore, the Fair was a 'contact zone' (Pratt I992) between the uncivilized and the civilized.

\section{Chinese exhibits at the Fair}

\section{Declining or accepting the offer to join}

As mentioned above, there was a Chinese exhibit on the Midway Plaisance. However, this Chinese exhibit was not constructed by the government of China, but by Chinese Chicagoans. Although the Qing government had been officially invited to the Fair with the mantra, 'All the World is here!' the government had wavered as to whether or not to accept the invitation, changing its decision several times and finally refusing. The reason given was the discriminatory immigration policies of the United States toward Chinese immigrants (Chicago Tribune, 23 December I89I). The Qing government cited a series of policies; by the time the plan for the Fair was made public, the US Federal Government had already implemented several discriminatory policies, beginning with the prohibition of naturalisation in I870. Five years later, Chinese women were restricted from entering the United States under the Page Law (1875). In I882, the notorious Chinese Exclusion Law was implemented, which forbade the new entry onto American soil of Chinese laborers for the next ten years, except for those who fell within 
an exempt class of applicants. ${ }^{\mathrm{I}}$ This act became known as the first American law prohibiting immigration based on ethnicity. The Scott Act of I888 prohibited the re-entry of Chinese laborers who had lived in the US and were temporarily outside of America.

What infuriated the Qing government most seems to have been the Geary Act, approved on May 5, 1892, which resulted in a worsening of US-China relations. This act initially appeared on the agenda of the US Congress with a view to extending the Chinese Exclusion Law for another ten years. One of its features was that it required even the Chinese who legally resided in America to apply for a residential certificate and carry it at all times. The act stipulated that any resident found without the certificate would be automatically regarded as an illegal immigrant and therefore be deported without due process of law. Therefore, the Chinese residents had to carry the certificate any time and anywhere they went. In this way, the residential certificate worked as an internal passport. The underlying intention of this new law was that the government wanted to distinguish illegal from legal immigrants. Newspapers reported numerous attempts at illegal immigration (Chicago Tribune, Io September I892: I6, 26 April I893; New York Times, 20 April I893: 2 May I893; Lee 2002, 2003). ${ }^{2}$ The government anticipated that once the Geary act was enforced, it would be easier to find and to deport illegal Chinese immigrants. The Chinese were the only ethnic group on which the US government imposed this measure.

It is easy to imagine that the Geary Act infuriated not only the Chinese residents in the US, but even the Chinese government, which had been demanding improved treatment of Chinese immigrants in the US based on bilateral treaties, such as the Burlingame Treaty of I868, which guaranteed free bilateral migration and the Angell Treaty of I880, with which the US government promised to provide adequate protection for Chinese immigrants. The series of racist immigration policies accounted for the Qing government's mounting rage, and as a way to protest and to save face, the Chinese government decided not to participate in the Fair.

Despite their government's stance, Chinese immigrants in Chicago wanted to have their exhibit at the World's Fair. Just like the Chinese government, they were very critical of the discriminatory immigration laws, but at the same time, they also lamented the Qing government's decision. They were afraid that they would lose the opportunity to properly present themselves to American society. The Chinese residents wanted to have a respectable and correct representation of the Chinese and China. They also wanted to correct the prejudices European Americans had against the Chinese such as the stereotypes that they were morally corrupt (addicted to opium and prostitutes) and agents of infectious diseases. Thus, they regretted that the Chinese government 
failed to join the Fair and decided to join on their own initiative and initiate a building project. This was made possible by donations from three Chinese Chicagoans: Gee Woo Chan, Hong Sing and Wong Fee. Chan worked as a doctor, while Sing and Fee were merchants. Thanks to them, the Temple of China, the Chinese Theater, and a garden, café and bazaar were constructed at the Fair. The local newspaper the Chinese American, published by the Chinese immigrant Wong Chin Foo praised these residents: 'The wealth of these three bright gentlemen were [sic] combined to give their country the first-class representation before the nations of the earth' (24 June 1893). This is how the Chinese exhibits came into existence.

\section{Displaying 'China'}

In examining the significance of the Chinese exhibits for the Chinese Chicagoans, there are three key points. First of all, the Fair attracted many Chinese immigrants from other parts of the United States to Chicago. They flocked to Chicago not just to enjoy the Fair, but also to seek employment. Many found jobs in laundry services or restaurants. To serve these Chinese laborers' daily lives, new businesses like grocery stores and curio shops opened (Lin I997). As a result, the Chinese population grew, as did Chicago's Chinatown. The first Chinatown had appeared in the south part of downtown Chicago, on Clark and Van Buren Streets, earlier in the I88os, as a result of the anti-Chinese sentiment in California, which had caused some Chinese to flee to Chicago. Thus, the growth of Chicago Chinatown in the I880 was a consequence of the eastward migration from California (Moy I995), while the Fair caused growth in the I89os. Even though the Chinese community became bigger, the number of women was extremely small. This was due to the Page Law of 1875 , the Chinese Exclusion laws, as well as the 'sojourner mentality' of Chinese culture, in which sons were sent to other countries as guest workers and their wives were expected to take care of parents-in-law at home in China. In I880, only three out of 209 Chinese in Chicago were female, less than I.5 per cent. By I890, even though the female population had increased, the ratio was still imbalanced: 3I out of I,503 or approximately 2 per cent were women. Chinatown was regarded as a bachelor society where prostitution was widespread and Chinatown became known as a vice district. This caused prejudices against the Chinese.

The second way in which the Fair was significant for Chinese Chicagoans was that the Fair provided them with an opportunity to gain recognition from American society, by representing China 'correctly' and not in a way that was prejudiced or distorted by American society. Some residents even affirmed that showing that they were good Chi- 
nese and that China was respectable was a way to obtain social recognition as good Americans and facilitate their assimilation into American society. Despite the prejudice and discrimination against them, they tried to become good Americans by being good Chinese.

Curiously, even though the Qing government and the Chinese Americans in Chicago shared the aim of saving face for China and Chinese subjects, their actions were in opposition. We assume that this was because the Chinese in Chicago were not only Chinese; they sought to be and needed to be Chinese and American at the same time. As long as they lived in the United States, they could not turn their back on America, but had to engage with it. Therefore, it is fair to say that the Chinese Chicagoans sought recognition by providing a 'correct' representation at the Fair, not only in order to show that China and Chinese people were respectable, but also to prove that they could become good Americans.

It is worth noting that Chinese people cared about both China and the entire Chinese community of Chicago. Chinese Americans, like Chinese in general, held a strong local or clan identity. They had established several associations for mutual help. The Chinese Consolidated Benevolent Association (or the Chinese Six Companies), an organization based on one's place of origin in China, was the most well known and influential among them. It had started in San Francisco in the mid-nineteenth century and later spread to other regions. In Chicago, the immigrants were divided mainly along the lines of their clans. It was reported that there were I4 factions in Chinatown around the time of the World's Fair; all of them were under the influence of the Six Companies (Chicago Tribune, I7 May I893). The strongest among them was the Moy family, which intentionally instigated and agitated internal discord in order to dominate Chinatown. They even had secret relations with the police and investigators, and made them raid their rival clans on trumped-up charges. The Chicago Tribune depicted these skirmishes as 'clan wars'. However, through preparation for the World's Fair and with the chance to represent China as a whole, the residents forged a group identity of being Chinese, which was more inclusive than the fractious local identities.

The emergence of a 'Chinese' consciousness does not mean that the dividing lines according to clan disappeared suddenly: Actually, vested interests in mounting the exhibition created a new source of conflict between the Moy and the Wong, the second most influential clan. This 'war' was exacerbated by a competitive bid to establish a Chinese exhibition at the World's Columbian Fair. Despite the efforts of the Moy clan, a company run by a Wong clan member named Wong Kee (Khe) was appointed to mount the exhibition. This defeat cemented the Moy clan's determination to ruin the Wongs and their allies (Chicago Tri- 
bune, 7 April I893). The conflict intensified; aggravated by a near fatal assault on a Northwestern University student and Wong clan member named Wong Aloy. On the night of March 29, I893, Wong Aloy came to Chicago from Evanston and was attacked in Chinatown. Although he survived, he was for a while in a comatose state (Chicago Tribune 7 , I2, I3, I6, 29 April I893). Two Moy clan members were accused of this attempted murder in court. The clan conflict continued.

Nevertheless, the World's Fair exhorted the residents to be aware that they were 'Chinese', a more overarching identity than a clan identity. Therefore, it can be said that the Fair provided them with an opportunity to acquire a Chinese identity in the process of becoming Chinese Americans. Although the dividing line by clan was still there, they now had a new identity of 'Chinese American', which would be able to consolidate all the clans. In other words, this was the emergence of a national identity in the context of China, and the sprout of an ethnic identity in the context of American society.

Last, but not least, the third significance of the Fair to Chinese Chicagoans was that it provided a contact zone between Chinese and Americans. Usually, the Chinese residents' lives were pretty much confined to Chinatown, and it was difficult for outsiders to visit this area (Light 1974) because it was believed to be 'a vice district', which was reported in newspapers such as the Chicago Tribune. American prejudices held that the Chinese were addicted to opium and prostitution (as there were few Chinese women; in fact, there were brothels staffed by Chinese in Chinatown for both Chinese and white men). Chinatown was associated with filth, depravity and danger, which were thought to be a threat to Christian civilization. It is true that some white people visited Chinatown and that most of them came for gambling, opium or prostitution. Due to this and the anti-Chinese prejudices of some Americans, the residential area for Chinese immigrants had the reputation of being a den of vice. Therefore, there were few opportunities for white Americans and Chinese to have direct contact.

Against this background, the Fair provided opportunities for the Chinese to show 'China' in a way they preferred, and also to do so directly to the general American public. They did this by building and exhibiting a temple, a theater, and a Chinese residence. In addition, they presented Chinese people dressed in magnificent traditional clothes. They also tried to introduce how to enjoy Chinese theater to the American public and some news papers such as the Tribune announced these activities (Chicago Tribune, I6, 26 April, 24 September I893). In this sense, the fairground allowed the Chinese people to 'show' and be seen. 


\section{The World's Fair as contact zone}

The relation between showing and being seen was, however, asymmetrical, because the Chinese Exhibits were placed on the Midway Plaisance, the field of 'the uncivilized,' while the civilization of America was represented in the White City. Such a space, where asymmetrical encounters take place, can be called 'a contact zone,' as initially suggested by anthropologist Mary Louise Pratt. She explained that such a zone is the space of colonial encounters, the space in which peoples geographically and historically separated come into contact with each other and establish ongoing relations, usually involving conditions of coercion, radical inequality, and intractable conflict' (Pratt i992: 6). As examples, Pratt depicted European adventurers and naturalists encountering 'the uncivilized' in Africa and South America. In this contact zone, European conquerors contextualized the cultures of Africans or South Americans in the European context and attributed inferiority to them. In other words, through their encounter with African or Southern American tribes, Europeans gained confirmation of their supremacy and the degree to which they were civilized. In the case of the World's Fair, even though the Chinese residents intended to introduce 'the finest part of Chinese civilization' to the American people, they were placed in the Midway Plaisance, the venue of 'the uncivilized,' in contrast to the White City, the venue of the 'civilized.'

In this sense, we can say that a contact zone is a sphere within which Orientalism, in the sense of Edward Said's usage, works, meaning that a certain group of people constructed "the inferior and exotic others" to secure and be assured of their superiority. At the Chicago World's Fair, a similar Orientalism was at play: the Midway Plaisance contrasted with the White City, through which "white" America reaffirmed its supremacy, supported by civilization and modernization, while trying to place 'the exotic others', such as the Chinese, Japanese, Javanese, Africans and native Americans, in their proper place, the field of the 'uncivilized.' Why, then, did American society need such a confirmation of its supremacy? The reason is that America was losing confidence in its own supremacy and its future due to the financial panics of the I89os, the rapid industrialization in cities such as Chicago, the high incidence of labor strikes, and the growth of 'new' immigration from Southern and Eastern Europe. All of these factors put a question mark next to the assumed national cohesion of America. In addition, at the time the historian Frederic Jackson Turner had declared that the United States had exhausted its frontier, that is, 'the existence of an area of free land, its continuous recession, and the advance of American settlement westward' (Turner I893: I99), which had served as a safety valve for American development. In a sense, America was 
suffering an identity crisis (Bramen I994; 2000). That is why the White City alone was insufficient; something else was needed to satiate America's need for a confirmation of its supremacy, that is, the Midway Plaisance as the arena of the subjugated. In this way, with the Fair as a contact zone, Orientalism was at work.

However, it should be noted that the Chinese Chicagoans were never resigned to silence and subjugation as 'uncivilized inferior barbarians.' This becomes clearer by looking behind the scenes at the World's Fair. There was resistance from the Chicago Chinese against the American society, which marginalized them. The acknowledgment and discussion of such resistance are missing in Mary Pratt's original idea of the contact zone. In the I89os, Chinese Chicagoans began to mobilize themselves to claim their rights as citizens of the United States. Led by a Chinese person, Wong Chin Foo, an organization called the 'Chinese Equal Rights League' was established in I892. Its primary purpose was political: gaining rights to naturalization, voting and citizenship. The group also developed an anti-discrimination law movement. Severely criticizing America, Wong pointed out that America could be neither fully modernized nor civilized as long as the United States retained discriminatory laws against Chinese immigrants. Citing former President Lincoln, Wong condemned American society for failing to embody Lincoln's ideals. He attributed the source of this discrimination to Christianity. Later, he and his organization would actually turn to Confucianism as a code of conduct to correct the 'evils' of Christianity. Wong believed that the modernization of America could be fully realized by being corrected by Confucianism. That is, the intermingling of American and Chinese ideas could make modernization and civilization perfect. In this way, the group used the logic of modernization and civilization to make a case to rid America of discrimination. In other words, if America ever wished to be fully modernized and civilized, it had to end discriminatory immigration laws. By relating the issue of modernization to the issue of discrimination against Chinese immigrants, the Chinese Equal Rights League criticized America.

In addition to demanding that America be completely modernized and civilized, Wong and his organization also strongly advocated for modernization to be taken up by Chinese immigrants and China. According to the group, this meant abolishing the habits of opium smoking and gambling. It also meant cutting the characteristic queue, adopting Western dress and speaking English. All of them Wong called 'Americanization.' As for China, the group expressed strong support for revolution and the overthrow of the Qing dynasty. Later, they became ardent supporters of Sun Yat Sen and claimed to have connections to him. They maintained that China should be modernized and become a republic. The group believed that through modernization of 
the Chinese immigrants as well as China, the Chinese could gain a respectable place in American society.

\section{Conclusion}

Thus far, the paper discussed the significance of the World's Columbian Exposition to Chinese Chicagoans on three levels, that is, the formation of community, social recognition and the establishment of a contact zone. What the Fair meant to Chinese residents of Chicago in terms of their own identity and orientation toward modernization was also mentioned. The emergence of identity and the discourse of modernization were closely linked to the discriminatory immigration laws in place in America at that time and the incipient identity of being Chinese American and their ideas about modernization were influenced by the concept of equality, an idea borrowed from American civilization. In this regard, there is a difference with the concept of modernization that prevailed in China at that time.

The Chinese Chicagoans struggled with different faces of modernization. One of them was the 'modernization' that American society imposed on them, which granted 'supremacy' to white America, while degrading the Chinese to 'inferior barbarian' status. Another face was the 'modernization' that the Chinese government promoted in order to avoid being colonized. The Chinese immigrants, living in the dual contexts of America and China, were thus caught between two nations. As Chinese and Americans, they chose to mount an exhibition at the Fair, unlike the Qing government, which rejected participation in the Fair. Such a duality, that is, belonging to both China and the United States, was recognized in Chinese Chicagoans' decision to establish the Chinese Exhibition as Chinese American. In this sense, the World's Columbian Exposition was not only a contact zone for the subjugator and the subjugated, but also the contact zone where Chinese and American identities intermingled.

\section{Notes}

I The exempt class comprised teachers, students, government officials, merchants, travelers, their families, and/or their servants, who were not subject to the Chinese Exclusion laws.

2 Correspondence exchanged among custom officers, who were in charge of the matter of Chinese immigration, also showed that the officers tried to locate and to expel Chinese illegal migrants. Some of these migrants came to the United States with false documents that claimed that the holder of the paper belonged to the exempt class. Others first arrived in Canada or Mexico and then were smuggled into America. This 
correspondence is stored at branches of the United States National Archives and Records Administration.

\section{References}

\section{Primary sources}

National Archives and Records Administration, Great Lake Region, Chicago, Illinois, Records of Immigration and Naturalization Service. RG. 85 Correspondence of the Chinese Division.

\section{Newspapers}

\section{Chicago Tribune}

Chinese American

New York Times

\section{Secondary sources}

Anderson, Benedict (1991), Imagined Communities: Reflections on the Origin and Spread of Nationalism. New York: Verso.

Bederman, Gail (1996), Manliness a Civilization: A Cultural History of Gender and Race in the U.S., 1880-1917. Chicago: University of Chicago Press.

Bramen, Carrie Tirado (I994), 'An Innocent Way Out': The Literature and Politics of Cultural Pluralism, 1880-1925. Ph.D. diss., Stanford University.

- (2000), 'The Urban Picturesque and the Spectacle of Americanization'. American Quarterly 52 (3): 444-477.

Cawelti, John G. (1968), 'America on Display' in Jaher, Frederic Cople (ed.). The Age of Industrialism in America: Essays in Social Structure and Cultural Values: 317-363. New York: The Free Press.

Doenecke, Justus D. (1973), 'Myths, Machines and Markets: The Columbian Exposition of I893'. Journal of Popular Culture, VI(3): 535-549.

Kikuchi, Hideaki (2005), Last Emperor to Kindai Chugoku: Shin-matsu Chuka-minkoku. Tokyo: Kodansha.

Lederer II, Francis L. (1972), 'Competition for the World's Columbian Exposition: The Chicago Campaign'. Journal of the Illinois State Historical Society, 65: 382-394.

Lee, Erika (2002), 'Enforcing the Borders: Chinese Exclusion along the U.S. Borders with Canada and Mexico, I882-I924'. Journal of American History, 89: 54-86.

-(2003), At America's Gate: Chinese Immigration during the Exclusion Era, 1882-1942. Durham: University of North Carolina Press.

Light, Ivan (1974), 'From Vice District to Tourist Attraction: The Moral Career of American Chinatowns, I880-1940'. Pacific Historical Review, Vol. 43 (3): 367-394.

Lin, Tsai-lun (1997), 'Image of an Ethnic Community: Chicago's Chinatown'. MA thesis, University of Illinois.

Mogi, Toshio (1994), 'Shinmatsu ni okeru 'Chugoku' no soshutsu to nihon'. Chugoku-Shakai to Bunka, 9: 25I-265.

Moy, Susan (1995), 'Chinese in Chicago: The First Hundred Years' in Holli, Melvin G. and Peter d'Alroy Jones (eds.), Ethnic Chicago: A Multicultural Portrait: 378-408. William B. Eerdmans Publishing. 
Parmet, Robert D. (1972), 'Competition for the World's Columbian Exposition: The New York Campaign'. Journal of the Illinois State Historical Society, 65: 365-38I.

Pratt, Mary-Louise (1992), Imperial Eyes: Travel Writing and Transculturation. New York: Routledge.

Rydell, Robert W. (1984), All the World's Fair: Visions of Empire at American International Expositions, 1876-1916. Chicago: University of Chicago Press.

Said, Edward W. (1979), Orientalism. New York: Vintage.

Turner, Frederic Jackson (I893), 'The Significance of the Frontier in American History'. The Annual Report of American Historical Association for 1893:197-227.

Yen, Ching-Hwang (1985), Coolies and Mandarins. Singapore: Singapore University Press.

Yoshizawa, Seiichiro (2003), Aikoku shugi no sozo: Nashonarisum kara kindai Chugoku o miru. Tokyo: Iwanami Shoten. 


\title{
4 Christianity and State-Building in Republican Chaozhou, South China
}

\author{
Joseph Tse-Hei Lee
}

\section{Introduction}

In the first half of the twentieth century, the Qing imperial order collapsed and the new modern state had not yet been established, so there was an opportunity for Chinese to search for new ideas of modernization and state-building. This chapter presents a case study of the relations between Protestant Christianity and state-building in the Chaozhou region of South China from I900 to 1930. Although twentiethcentury Chinese nationalism was predicated on secularism, the reach of Christianity, repressed but far from domesticated, returned to haunt the secular state from the late Qing to the Republican era. By examining church-state relations during that period, this study investigates the making of the Chinese nation state through the prism of the continuous tension between religion and nationalism. It analyzes the conflict between Christianity and state power, as well as the influence of the state on the religious and political identities of Chinese Christian communities. It also explores the meanings of key concepts like 'sacred and profane', 'public and private' and 'state and society' as they relate to church-state relations, the expansion of state power and collective behavior.

Rather than separating the sacred and the profane as two separate spheres, this study re-conceptualizes church-state relations as an integral part of religio-politics in Chinese society. At the centre of the discussion is the relationship between state power and religion. In recent years, Anthony C. Yu at the University of Chicago has called for more attention to the state's control of religion during the imperial and contemporary eras in China. According to $\mathrm{Yu}(2003)$, 'there has never been a period in China's historical past in which the government of the state, in imperial and post-imperial form, has pursued a neutral policy toward religion, let alone encouraged, in terms dear to American idealism, its "free exercise". The impetus to engage religion, on the part of 
the central government, is for the purpose of regulation, control and exploitation whenever it is deemed feasible and beneficial to the state' (Yu 2003: 4). The Chinese imperial dynasties of the past and the Republican state of the early twentieth century have continuously pursued a policy of engaging religions as long as these religions supported the state.

This research expands on Anthony C. Yu's argument and points out that the complexity of church-state relations can be better understood if one takes into account the involvement of Chinese Christians in negotiating with the state over sacred and secular matters. In twentieth-century China, the church, the state and the community constantly negotiated with each other over the control of religion, religious institutions and rituals. When the state was strong, the church and community participated in the formation of state power. But as the state's power declined, the church and community reverted to their original autonomy and they crossed the boundaries between sacred and profane in order to claim political, social and economic influences. The church and community were active agents that contributed to the theories justifying the state's claim to legitimacy. At the grassroots level, the situation was further complicated by the impact of pre-existing internal conflicts that had shaped the interactions between church, state and community. Therefore, the contest for religio-political power is a focus of discussion (Lee 2003a; Lee 2003b; Lee 2004; Lee 2005; Lee 2007a).

Furthermore, this article provides a unique perspective on state-society mediation by looking at Protestant churches in Chaozhou during the Republican era. Historians have often portrayed foreign missionaries as undermining state authorities and upsetting the state-society balance in China. This study contextualizes Protestant missions and Christian churches within the traditional patterns of state-society mediation. While the local Christians negotiated with the state authorities, they simply used the missionary enterprises as additional political and social resources. During the I9Ios, civil unrest enabled foreign missionaries to emerge as effective mediators between competing factions in local politics. This mediating role was undermined in turn by the rise of anti-imperialism in the early I920s. But the change of political climate allowed some Christian communities to gain autonomy from the control of missionary enterprises, to accommodate the growing $\mathrm{Na}$ tionalist party-state and to contribute to the state-building process.

Methodologically, this research employs a social history approach to investigate the nature of religion and state power at the local or grassroots level of Chinese society. This approach, known as 'history from the bottom up', looks at particular Christian communities on their own terms. The main contention in this study is that to search for a new basis for the Chinese state and nation, Christian leaders in Chaozhou 
drew on a wide range of political and cultural resources, foreign and native, national and local, modern and traditional. They integrated Christianity into the state-building process through the efforts to initiate social reform, mediate warlord conflicts, provide welfare and reconcile their religious and national identities. They effectively employed Christian missionary resources to achieve modernity by Western standards while maintaining a distinctive Chinese identity and pursuing their local agendas. This pattern of Christian religious activism highlights the role of human agency in the process of state-building in early twentieth-century China (Dunch 200I: 80-I77).

Beginning with an overview of Christianity in Chaozhou in the years before I900, this study discusses the symbiotic relation between mass conversion and anti-Christian violence in the interior. The period of I900-I920 saw the growth of a national consciousness and of China's revolutionary movement. The foreign missionaries and native Christians repositioned themselves as a modernizing force within local society. But during the I920s to I930s, the expansion of party politics and the growth of revolutionary nationalism marginalized Christian communities in local politics. The Anti-Christian campaigns of the I920s reflected an intense negotiation between church and state in a specific local setting.

\section{The Baptist and Presbyterian churches as power holders in Chaozhou}

On the map of China, Chaozhou seems to be an isolated region. Located on the South China coast, Chaozhou was far away from the central and provincial governments and notorious for its long history of rural violence. The Chaozhou dialect was the dominant language in the coastal areas, whereas the Hakka dialect was widely spoken in the poorer interior. Since the eighteenth century, large numbers of people from Chaozhou left their families to look for job in Siam (now Thailand), planning to return to China upon retirement. While living abroad, they maintained close contacts with their home villages through strong kinship and native place ties, which provided an effective network of support. Beginning in the I830s, American Baptist missionaries who preached among overseas Chinese in Siam found in the process a way to reintroduce Christianity to the Chinese mainland (Christianity was banned as a heterodox religion in China since I724). They encouraged overseas Chinese converts to spread the Christian faith through native place networks abroad in Siam and, later, through kinship networks after they returned to China. Because these networks were outside Chinese official control, they provided a stable and effec- 
tive channel of religious transmission to facilitate Baptist expansion from Siam to China. Christianity was thus not simply a foreign imposition but spread through specifically Chinese venues. This pattern of development in the I83os highlights the importance of established Chinese maritime routes from Siam to Chaozhou in missionary efforts to bring Christianity to the Chinese mainland before the creation of the unequal treaty system. This system was institutionalized by the treaties of Tianjin ( 1858 ) and of Beijing (I86o), which encouraged the toleration of Christianity, permitted the missionaries to preach across the Chinese empire, and ordered the Chinese government to protect native Christians from persecution.

The Beijing Convention of I86o laid down the framework for Christian expansion throughout the late nineteenth century. The treaty opened Chaozhou prefectural city (Chaozhoufu) as a new treaty port, but due to strong anti-foreign sentiment, foreign diplomats chose to move to Shantou, about $60 \mathrm{~km}$ from the prefectural city. After establishing themselves in Shantou, the Baptist and Presbyterian missionaries encountered much hostility from Chinese literati, government officials and lineage elders in administrative cities and market towns. Faced with these antagonistic power holders, the Baptist and Presbyterian missions shifted the focus of evangelization towards the interior (Lee 2003a: I-I6).

Before the Communist Revolution of I949, most villages in Chaozhou were fortified settlements dominated by several lineages and were multi-surname communities. The proliferation of lineages characterized the political landscape in Chaozhou throughout the eighteenth and nineteenth centuries. Lineages were corporate units. Men from the same lineage organized themselves into a defence group during the frequent raids on other lineages. In areas with little government control, lineages were responsible for investigating alleged crimes committed by any members, and acted collectively in cases of disputes with outsiders. Beyond that, lineages were of economic significance because the lineage elders were in charge of distributing communal resources such as land, water and firewood among all the members. Communal rituals and ancestral worship were held to maintain lineage cohesion.

Equally important were temple organizations, which coexisted with lineages and helped maintain communal solidarity through the holding of temple festivals. These festivals drew the boundary between village insiders and outsiders (Eng and Lin 2002). People who had always made contributions to temple activities were considered to be insiders and given access to the use of land and water resources for agricultural production. People who had formerly participated but were reluctant to become involved after conversion to Christianity were viewed with suspicion and hatred. The situation became more complicated when some 
villagers joined the Christian church and broke away from the lineage and temple communities.

Throughout the late nineteenth century, there were many reports of villagers seeking the help of the Baptist and Presbyterian missions. William Ashmore recalled a meeting with an elderly man, who visited the Baptist mission compound in the midst of the imperial government campaigns against those fortified 'rebellious' villages (feixiang). The old man asked Ashmore to establish a chapel in his village. Suspicious of the visitor's motive, Ashmore enquired as to whether the government forces had been to the village yet. The old man replied that the troops would pass through his village soon, and urged Ashmore to go with him at once. After hearing the reply, Ashmore asked the visitor to settle all problems with the local government before joining the church. When Ashmore wrote about this incident in I899, he taught the new missionaries to be wary of some Chinese adherents joining the church merely for protection. Nonetheless, the Baptist converts in Shanhu and Quxi villages were successfully exploiting the missionary resources to their advantage. The more hostile the government forces, the more likely some villages would affiliate with the Christian missions (Lee 2003a: 47).

Overall, Protestant Christianity in Chaozhou grew as a grassroots movement, appealing to a large number of people in the remote areas. With more baptisms in the interior than on the coast, conversion in Chaozhou was predominantly a rural phenomenon. It was the countryside, not urban areas that became the center of Christian movement. The higher concentration of church members in the interior challenges Paul A. Cohen's argument that in late imperial China, people along the coast were more likely to subscribe to Christianity than people in the hinterlands. These rural Christians came from diverse social backgrounds: they were farmers, artisans, merchants, medical practitioners, beggars and widows. Rather than living on the fringes of the society, they were deeply integrated into the political, social, economic and cultural spheres of the local communities. They successfully used their social networks to bring relatives, neighbors and friends to the churches, a pattern of church growth that not only fitted well with the missionary expectation of self-propagation through native agency but also marked the beginning of mass conversions in grassroots society (Lee 2007a).

Equally significant was a considerable overlap of Chinese kinship and Christian identities. Where the churches were erected outside the walled villages and surrounded by Christian households, they were often misunderstood as independent Christian settlements. In fact, these Christian households constituted an essential part of the local community, as they identified themselves with a particular denomination and their own lineage or village factions. This remarkable overlap of reli- 
gious, kinship and territorial identities characterizes most of the Baptist and Presbyterian congregations in Chaozhou (Lin 2003; Liu 2003).

As Christianity began to take root in Chaozhou, the complexity of political issues involving foreign missionaries and Chinese converts were acute. Initially, cases of anti-foreign and anti-imperialist disputes broke out in the treaty port of Shantou, district cities and market towns where foreign missionaries were concentrated. They were spreading into the interior and were woven into the local kinship, intra-lineage and intra-village conflicts, through the influence of Chinese Christians. Not only did missionaries and converts provoke violence, wittingly or otherwise, endemic violence and pre-existing resource conflicts themselves became Christianized, as local rival factions searched for new sources of influence and identity to strengthen their positions. Missionaries were often at a loss to know where they stood because intralineage/-village conflicts and anti-Christian violence frequently overlapped. In particular, Protestant denominational differences and Christian sectarian competition could only too easily be wedded to longstanding disputes in a deeply divided society. Even experienced missionaries were open to exploitation by opportunists seeking Christianity for political, social and economic advantages rather than genuinely religious consolations. The missionaries' ability to successfully intervene in local conflicts had to do with powerful backing from foreign powers in Shantou and beyond. Through their effective intervention, missionaries could provide an alternative source of authority, thereby empowering the Christian communities and undermining the traditional power holders such as lineage leaders, temple managers, local constables and yamen runners (Lee 2002). In areas notorious for a long tradition of collective violence and little government control, the church became what English Presbyterian missionary John Campbell Gibson called 'a protective society', whose members and leaders would help each other in all matters of disputes and litigations (Gibson I9or: I84). It is an improbable situation that the Baptist and Presbyterian Christianities expanded into Chaozhou in the midst of social unrest and became a powerful institution in rural politics. This political feature of the Protestant missionary expansion into Chaozhou, similar to that in late nineteenth-century Shandong province studied by R. Gary Tiedemann and Lydia Gerber, reveals that Christianity became a potent new element in Chinese local politics (Tiedemann I99I; Gerber 2004).

Institutionally speaking, the Chinese Baptist and Presbyterian churches followed a set of rigid regulations enforced by the missionaries, but the Western approaches to church implantation were a radical departure for rural China where human interactions were shaped by different types of social networks. In Chaozhou, the status of the local church founders, their personal networks and the factions to which 
they belonged were extremely important. It was these variables, not the missionaries' rigid regulations, that determined how the church should be constructed, and who should be included and excluded in a Christian community. While this study emphasizes the use of kinship and lineage networks in church implantation, it does not deny the impact of the Baptist and Presbyterian Church regulations, the personalities of particular missionaries and Chinese evangelistic staff, and the specific local circumstances. For example, the Baptist and Presbyterian missions created two different institutional forms of Christian church networks, each adhering to a particular missionary enterprise and foreign power. Under the Baptist model, the diffusion of church authority to local congregations gave rise to an extensive network of loosely organized Christian villages. Under the Presbyterian model, the centralization of church authority in the Presbytery integrated all the congregations into a hierarchical confederation that was oriented towards Shantou. Despite the denominational differences, the internal distribution of power within the Baptist and Presbyterian churches was organized vertically, because the church leaders were also the dominant figures in the Christian lineages or sub-lineages. One implication of this vertical hierarchy was that the Christian leaders could easily monopolize the management of local church affairs and even turn the church into their new power bases. These political features of church implantation had a far-reaching impact on the interactions between church and state in the early twentieth century.

\section{The Protestant Church as a modernizer after 1900}

The outbreak of the Boxer Uprising (I899-I90I) completely changed church, state and community relations in modern China. By the end of I900, there were powerful forces in favour of the Christians. In October 1900, the Imperial Court was in exile to Xi'an. Li Hongzhang, the governor-general of Guangdong and Guangxi provinces along with other coastal governors proposed to make peace with the Allied armies. The central government reversed its anti-foreign stand and ordered all the provincial authorities to protect Christian churches from the Boxers' attacks (Guangxuchao donghualu 1958: 4526; Lee 2002: 234). The failure of the Boxer Uprising increased the prestige of Western missionaries and the Christian church was now looked upon as a powerful political institution on Chinese soil.

In the meantime, the imperial officials and literati realized that China could not survive without modernizing herself based on the Western model. Therefore, the central government introduced the New Policies to restructure the military and the education system in order to 
transform China into a modern state. When the Confucian civil service examination was abolished in I905, the government put in its place a Western-style education system. Western-style education had begun with missionary schools in the treaty ports, but these schools and their students were concentrated along the coast of China and existed at the fringes of Confucian society. Education along Western lines was considered to be a technical training for various professional careers rather than a process to train imperial government officials. But the New Policies redefined education so as to make it a means to create good citizens, to train competent officials and to enrich the nation. In this new political climate, Christian educational missionaries were recruited to run state schools and train teachers for the new system (PCE, FMC, series I, box 42B, folder Io). This development completely transformed the educational landscape across China as shown in the studies of Stig Thøgersen (2002) and John R. Stanley (2004). Although the patterns of Christian involvement in educational reform varied from place to place, both the Catholic and Protestant missionaries successfully created an extensive network of private educational facilities in parallel with the government-run school system (Ashmore I902: 87-II9; Hood I966; Du 2005: 16-51). A good example is the Anglo-Chinese College, founded by the English Presbyterian mission in May I905 and sponsored by Chen Yuting, a wealthy merchant in Shantou, to offer Western-style education for young people (PCE, FMC, series I, box 3I, folder 7). What was striking about this Sino-Western educational project was that the Anglo-Chinese College was erected in Shantou rather than the Chaozhou prefectural city. This reveals that the local merchants and landholders with considerable political, socioeconomic and cultural resources were determined to bypass the prefectural and district authorities and to rely on the Western missionaries to provide modern education outside the prefectural city.

While Christian missions had contributed to the rise of nationalism through the spread of Western ideas, the development of Western-style education, social reforms and other evangelistic activities subversive of the old social order, their success as an agent of change opened the door to secular ideas that attracted young people in search of China's salvation. As Chinese accepted modernization as a critical component of national salvation, they embraced the importance of science and technology. A nationwide conversion to science and technology took place in dramatic fashion during the first decade of the twentieth century (I900-I9I0). This marked a significant step in China's search for modernity. In contrast, conversion to Christianity proceeded slowly, for it was the Western technical advance that impressed the Chinese most (Wang 2003; Yip I982; Yip 2003). In the name of science and technology, many intellectuals in the early Republican era rejected the civiliz- 
ing mission of Christianity and saw the Christian faith as redundant in the modern world. John Fitzgerald correctly points out that Chinese awakening was a secular phenomenon (Yip I980; Fitzgerald I996: 37). As nationalism became the dominant discourse in national and regional politics, there were growing attacks on Christian missionary enterprises and Chinese denominational churches.

In parallel with the rise of nationalism was the expansion of Sun Yat Sen's revolutionary movement. Prior to the I9II Revolution, the late Qing New Policies created a generation of young people who had been taught radical moral and political values calling for absolute loyalty to the Chinese nation. But the state nationalism promoted by the late Qing reformers went beyond the government control because of the spread of Han Chinese nationalist ideologies in newspapers and the rapid growth of revolutionary activities (Harrison 200I: 8I-I3I). It is against this background of political radicalism that the interaction between endogenous and exogenous forces of change will be examined in post-I9II Chaozhou.

In the early twentieth century, the treaty port of Shantou was controlled by the Shantou Chamber of Commerce. The merchants and their military police responded on November 5, I9II to a call from the revolutionaries in Guangzhou for self-government, and they established an armed merchant corps to extend their power. But when the old Governor-General of Guangdong drew back from provincial independence, the Shantou merchants hesitated to act. Only some young radicals seized the opportunity to occupy the banks, salt offices and centers of communication in Shantou. These radicals were predominantly Hakka-speaking journalists, schoolteachers and writers. They organized themselves into the Chinese Revolutionary Alliance. The Shantou Chamber of Commerce saw the latter as a competitor for power in the post-revolutionary era and therefore, was determined to crush it (Friedman 1970; Galbiati 1985: I-53).

Underlying this power struggle was a sub-ethnic conflict in which the Chaozhou-speaking Shantou Chamber of Commerce was worried about the expansion of the Hakka-dominated Chinese Revolutionary Alliance. Through an alliance with Chen Jiongming, the man chosen as provincial governor in Guangzhou in I9I2 and the support of British and American consuls, the Shantou Chamber of Commerce kept the Hakka radicals out of power. Clearly, the wealthy men in Shantou only supported the revolution provided that they could keep the salt revenues and other financial resources to themselves (Wang and Wu 2003). Of particular importance is the theme that allegiance to local community and concern for communal interests often took precedence over loyalty to any political regime. This theme was replayed on countless occasions in Chaozhou throughout the Republican era. 


\section{The Church as a mediator in warlord conflict}

Although the Shantou Chamber of Commerce won the power struggle, they failed to use the I9II Revolution to implement progressive reform and to extend their control into the countryside. Their reliance on foreign protection seemed to preclude any need for establishing a better form of governance. As a result of ineffective state control, intra/intervillage violence frequently broke out in the interior of Chaozhou throughout the I9IOs (China Records Project, the Ellison and Lottie Hildreth Papers, RG I5, box 3, folder 28).

Strategically located at the border of Fujian and Guangdong provinces, Chaozhou was a place of contest between rival warlords. In the winter of I9I7, Chen Jiongming's troops advanced upon Fuzhou troops stationed at Chaozhoufu. As one Chinese writer observed, 'Outside the city wall there was severe conflict. The sound of cannon thundered in the sky. Bullets fell like raindrops. Residents of both city and villages were fearful of death' (China Records Project, the Ellison and Lottie Hildreth Papers, RG I5, box II, folder II8). The local chief of police and the chair of the Chaozhou Chamber of Commerce asked T.W. Douglas James and Malcolm Ross of the English Presbyterian mission, Ellison Hildreth of the American Baptist mission, and Father Roudière of the Missions Étrangères de Paris (MEP) to act as negotiators between the opposing armies. The missionaries set up a joint committee with the local chief of police and merchant leaders to draft an armistice. With the intervention of the American and British consuls in Shantou, the missionaries brought Chen Jiongming's troops to the negotiation table. Eventually, an armistice was arranged and the Fuzhou troops withdrew from the area. To commemorate this event, a granite monument was put up in the spring of I9I8 at the largest temple in Chaozhoufu. Each missionary was presented with a banner (I4 feet long and 30 inches wide) with four Chinese characters in gold thread, translated as 'coming to the aid of people in distress' (Hood I986: 215-2I7).

In this incident, the missionaries' intervention saved the city from attack. In Chaozhoufu and Shantou, the missionaries were now seen as guardians of law and order. They gained prestige and acceptance in the circle of local elites. There was even an informal political alliance between the missionaries and local merchants. As with the native Christians, the merchants could use the missionaries to gain access to the foreign consuls in times of crises and to obtain additional resources to resist the provincial armies in Guangzhou.

This experience encouraged T.W. Douglas James to pursue closer relations with the local elites who had sought his help. Ever since their arrival at Chaozhoufu in I860, the English Presbyterian missionaries had failed to establish a foothold inside the walled city. T.W. Douglas 
James took advantage of the new political climate to relocate the Presbyterian mission compound outside the southern gate into the center of the city. As he discussed the change of popular mood towards the Presbyterian mission,

When in December 19I7, the missionaries were able to act as mediators between the opposing forces it was as representing the local people, and at the instance of the local gentry and for the purpose of saving the whole City [Chaozhoufu]. When we came in from the Southern Camp it was between rows of anxious people lining the long streets; and when we entered the Chamber of Commerce it was to be greeted by silent and impressive rising to their feet of 50 or 60 men who knew that their lives and fortunes hung on the news we brought. It struck the imagination of the men most concerned and they have not wearied of showing their appreciation and gratitude. We did little but we were on the spot and God uses us (Hood I986: 388, endnote 59).

While the missionaries were trapped in a warlord conflict, the only option for them was to exercise their treaty rights by appealing to the foreign consuls for help. In this incident, the close connection between the Bible and the gun proved to be a blessing in disguise. To the local officials and merchants, reliance on the foreigners to protect their interests precluded any needs for cultivating better relations with the warring factions in Guangzhou and Fuzhou and for creating strong defence forces. But the tie with the missionaries and foreign consuls was their weakness as well as their strength. The local officials survived a military crisis, and the merchants and absentee landlords continued to prosper in these relatively safe urban enclaves. But these power holders failed to implement progressive reforms, to address the grievances of rural communities and to establish law and order in the countryside. Therefore, the political climate of Chaozhou followed the fluctuating fortunes of Chen Jiongming. From 192I onwards, Chen was increasingly in conflict with Sun Yat Sen, and this power struggle added a new dimension to the politics in Chaozhou.

In I920, Sun founded the new Guomindang in Guangzhou to rally mass support. But Sun's position in Guangzhou depended on the city's warlord politics. Real power in Guangzhou shifted between Chen Jiongming and the mercenary troops from Yunnan and Guangxi provinces that Sun had invited into the city to counter Chen's power. After Chen's successful expedition against Guangxi warlords in May-July I92I, his rivalry with Sun intensified. Sun used Guangzhou as a power base to organize a Northern expeditionary campaign in alliance with 
Zhang Zuolin in Manchuria against Wu Peifu in central China. Sun's goal was in conflict with Chen's policy of putting the interests of Guangdong first, 'Guangdong for Cantonese'. Sun's temporary flight from Guangzhou in 1922 was followed by Chen's own expulsion from the same city in I923. When Sun returned to reorganize the Guomindang with the help of the Soviet Union, Chen simply retreated to his traditional base in East Guangdong. As a local man and a native of Haifeng district, Chen directed resources towards local development. Chen was hailed in the Presbyterian missionary circle as a symbol of law and order and a guardian of local economic interests. Despite his remarkable contributions to the development of East Guangdong, Chen was still a warlord and his troops often disturbed the local Catholic and Protestant communities.

\section{The church as a welfare provider in natural disasters}

While fighting and troop movements severely affected the people's livelihoods in Chaozhou, natural disasters such as earthquakes, droughts and typhoons put tremendous pressure on local resources. The typhoon and tidal wave of August 2, I922 swept across Shantou and its surroundings. Hundreds of corpses and the carcasses of animals were mingled with the debris. It was estimated that 75 per cent of the city buildings in Shantou were destroyed. The Mother Superior, Sister Marie du Rosaire who was in charge of the Ursuline convent at Shantou was caught in the tidal wave that followed the typhoon. She floated on a drifting bed until daybreak when she was rescued. Sister Marie du Rosaire later described the magnitude of the disaster in one of her letters:

Swatow alone has 50,000 dead - either lost or drowned. At every moment of the day or night the stretcher-bearers pass in front of the [Catholic] bishopric with their dead. At first they had coffins; but now the bodies are simply put in matting. They have been picking them up now for five days. The Chinese are very respectful of their dead and will not let anyone go without burial. The way the Chinese have taken this disaster is truly remarkable. They don't seem to be crushed. They collect the debris from their houses and their little bamboo huts as though it were something quite ordinary (Mahoney 1996: 35-36).

This graphic account of the disaster showed that Shantou was like a war-torn city. The material damage was enormous and the number of casualties was uncountable. Many Baptists and Presbyterians in coastal 
villages were drowned. A Presbyterian rural congregation was reported to have lost 250 of its members, and of one Christian family numbering 25 only three survived (Band I948: 350; Hood I986: 216-217).

Although the Baptists and Presbyterians were little prepared for it, the foreign missions and native churches found themselves to be the only viable institutions after the disaster, and as such, had to bear the burden of relief work (Jenkins 2002; Sanneh, 2003: I4-20). In Shantou, the Baptist and Presbyterian missions together with the Shantou Chamber of Commerce coordinated the relief efforts to bury the dead and to distribute food among the poor. The missions also used their extensive market and village church networks to distribute food and medicine in the countryside. One of the badly hit Christian communities was the Presbyterian congregation in Yanzao village in Chenghai district, the first Presbyterian Church in Chaozhou. The Yanzao congregation lost II9 of its members, 50 baptized adult church members, 35 children and 34 religious inquirers. The death toll made up 25 per cent of the village population, of which three deacons and one elder were killed, and one Christian family lost eighteen of its members (Wei I949: I-4). Chen Chunsheng points out that after the typhoon, many emigrant villages (qiaoxiang), such as Zhanglin market town in Chenghai district, where local inhabitants received remittances from Southeast Asia, turned to their overseas relatives for help (Chen 1997). What distinguished the Yanzao congregation from these emigrant villages was its tie to the extensive regional and transnational Presbyterian networks. The Yanzao congregation called for financial assistance not only from their missionary patrons in Shantou and other Christian communities in unaffected areas, but also from the Chinese Presbyterian migrants in Hong Kong, British Malaya and Singapore and from the headquarters of the English Presbyterian mission in London.

Most of the overseas donations were administrated through the English Presbyterian mission in Shantou and in 1923 the majority of the missionaries were involved in relief and charitable work. They addressed the immediate concerns of the refugees and rebuilt the badly hit communities through provision of livestock, farm implements and loans to farmers. The Presbyterian mission certainly welcomed the opportunity to make contacts with local officials and merchants (Band I948: 35I). Despite the missionaries' optimism, there was a growing concern over the future of the Guomindang-Communist United Front government in Guangzhou. The outbreak of the Anti-Christian Movement there in December 1924 alarmed the missionaries and church leaders in Shantou. 


\section{The church as a target of the Anti-Christian Movement (1925-1927)}

The Anti-Christian Movement was an integral part of revolutionary politics in the Ig20s. Michael G. Murdock argues that the Guomindang leaders manipulated anti-Christian sentiment to rally support as a mobilization tactic. In so doing, the Guomindang government used this as leverage to maintain ties and continue talks with foreign powers that had refused to recognize it. This tactic extended far beyond the Guomindang's power basis in Guangdong province and allowed the party to expand its influence through local anti-Christian organizations (Murdock 2000; Murdock 2002; Murdock 2006).

During the First Eastern Expedition in the spring of I925, the Guomindang leaders in Guangzhou decided to remove the threat of Chen Jiongming and his troops in Eastern Guangdong. The training regiments of the Whampoa Military Academy and the Peasant Unions of the Hailufeng area contributed to the success of the Eastern Expedition. After defeating Chen's troops, the Guomindang controlled Shantou and its hinterlands. The Guomindang permitted the formation of Labour Unions and Agricultural Societies and allowed them to denounce Christianity as a vanguard of Western imperialism and Christians as the 'running dogs' of the foreigners. The Guomindang armies acted with caution in relation to the foreign community in Shantou. The Baptist and Presbyterian missions continued their ministerial, educational and medical work despite the anti-imperialist and antiChristian agitation of the Guomindang. When there was an attempt to organize an anti-Christian demonstration in Shantou on May 4, I925, the Presbyterian school students withdrew in protest from the student union. Although a newly formed pro-Guomindang student union launched a bitter anti-Christian campaign in Chaozhoufu, students of the Christian schools did not participate (China Records Project, the Ellison and Lottie Hildreth Papers, RG I5, box 7, folder 94). In Haifeng and Lufeng districts, the Peasant Union declared its policy to expropriate the landlords, to expel foreigners and to destroy the churches. With the support of the Guomindang authorities, bands of students went to the countryside, propagating communist and anti-religious ideas.

The most severe challenge to the Baptist and Presbyterian missions was the May $30^{\text {th }}$ incident in Shanghai and the Canton-Hong Kong strike in June I925. In areas controlled by the Guomindang government in Guangzhou, the May $30^{\text {th }}$ and Shamian incidents added fuel to the explosive anti-imperialist and anti-Christian agitation. In Chaozhoufu, the local Christians were concerned for their safety, when students at two of the state schools were seeking rifles to arm themselves against the Christian institutions. In Shantou, the Student and Labour Unions planned to organize anti-foreign demonstrations. Although ru- 
mours of the return of Chen Jiongming's troops reduced the scale of the protest, a citywide strike and boycott took place throughout late I925 and early I926 (Hood I986: 228-231).

The popular reaction in Shantou to the May $30^{\text {th }}$ and Shamian incidents had its immediate effect on the English Presbyterian mission. The Presbyterian educational missionaries had to withdraw from the Anglo-Chinese College and leave it in the hands of the Chinese staff. The most hostile reaction towards the English mission was expressed by a group of Chinese Christians in the Shantou Church, the largest Presbyterian congregation in the city. On their initiatives, a Patriotic Society was formed along with members of the Qilu Church, another Presbyterian congregation in the suburb of Shantou. Dispute was caused by their attempt to change the name of their church by adding 'Chinese Christian' to the existing 'Presbyterian Church'. The missionaries saw the change as a plot to gain control of the mission and church properties. The dispute reached a climax when an announcement was made in the name of the Shantou and Qilu congregations declaring that as the missionaries had not condemned the Shanghai shootings, the two congregations decided to break away from the English Presbyterian mission. Some radical church leaders were determined to separate themselves from the Synod and they called upon other Presbyterian churches to do the same.

When the deacons of both congregations met together to discuss the dispute, those responsible for the announcement refused to attend. At the end, the deacons issued a statement to emphasize the denominational link with the English mission, but they pointed out that the Shantou and Qilu congregations had been financially independent for over ten years, and they were self-supporting pastorates in the Presbytery. Underlying this incident of intra-church dispute was serious friction between the missionary patrons and some well-established church leaders (Hood i986: 232-234). When some church leaders internalized the Guomindang discourse of revolutionary nationalism, they challenged the subservient role assigned to them by the missionaries and were determined to break away from the missionary control.

In August 1925, the pro-Guomindang Anti-foreign Committee in Shantou issued a resolution that prohibited teachers and students from attending any school under British control. Hur F. Wallace, the most senior Presbyterian educational missionary realized that he could not open the Anglo-Chinese College for the coming term. The missionaries were convinced that the Anti-foreign Committee had its contacts with the Shantou Church, because Wallace announced on August 22 that the Anglo-Chinese College would be suspended for a term. Within a few days, Wallace received a request on behalf of the Student Association that the Mission Council should hand over the temporary manage- 
ment of the College to a Chinese Committee. The Presbyterian mission saw it as a way to circumvent the resolution. As the missionaries refused to back down, some students were reported to have organized a new school in order to cut themselves off from the British missionaries. With the support of two sons of the founder of the Anglo-Chinese College, Chen Yuting, the students wanted to re-register the school property as 'common property' rather than 'British mission property'. This confrontation between the Presbyterian missionaries and local students was suddenly transformed by the military comeback of Chen Jiongming's forces and the departure of the Guomindang officials. The change in the military situation affected the decision of the local church leaders. In the autumn meeting of the Presbytery on September 22, I925, the local church leaders re-established contact with the missionaries, but they refused to condemn 'the unruly section of the Swatow (Shantou) congregation' as the missionaries would have wished (Hood I986: 235-237; Hu 2004b: I06-I22).

Nevertheless, Chen Jiongming's military intervention failed to establish a new stronghold in Shantou because in November I925, Jiang Jieshi launched the Second Eastern Expedition against Chen's forces. The return of the Guomindang army brought in Zhou Enlai as chief director of the Civil Administration Department of the Eastern Expedition Headquarters. During the next few months, Zhou Enlai took over the control of mission schools from the hands of the missionaries, including the Anglo-Chinese College, but he had no resources to pay teachers and keep schools running. In this incident, Zhou Enlai settled political scores at the expense of the students' future (Hood I986: 237-246; Chen [comp.] 2004).

As Jiang Jieshi tightened his control over the Guomindang, he began to target the Communists and ended Zhou Enlai's administration in Shantou. The Anti-Christian Movement officially ended in the winter of 1926 and things returned to normal in early 1927. This change of revolutionary policy had to do with political and social instability in the countryside. Throughout the Hakka region stretching from Haifeng district to the borders of Jiangxi province, cases of inter-/intra-village violence merged with continuous fighting between Communist and anti-Communist forces. There was an extensive attrition of missionary activity over this vast mission field than that in Shantou, with fewer staff, Chinese and foreign missionaries to serve it. The most serious problem had to do with the killing of local Catholics and Protestants in Haifeng and Lufeng districts under the control of Peng Pai's Soviet government. In October 1928, six churches were burnt and another I8 churches were demolished, with three preachers, an old elder, six deacons and 30 Christians killed and many becoming homeless and fleeing elsewhere (Hood I986: 247-256). 
It is ironic that during the Northern Expedition, the anti-Christian movement increased popular support for the Guomindang leaders, but the escalation of violence against Christians undermined the government's ability to establish effective control over the newly controlled areas. The Guomindang decided to end the anti-Christian movement in order to maintain social stability and prevent foreign intervention (Murdock 2006: 2II-278).

In the midst of political chaos, there were more incidents of intrachurch dispute during the late I920s. The Jieyang Presbyterian congregation had declared itself an independent church. They complained about the slow progress towards self-support and self-government within the Presbyterian circle. The Shantou Church had petitioned the Presbytery to have more control over its resources. But the Presbytery and the English missionaries rejected the idea that the stronger congregations could enjoy independence by disassociating themselves from the weaker ones. The dispute revealed a growing rift between this wellfinanced urban congregation and the missionaries. In November I928, the dispute ended with a final split. Seven leaders of the Shantou Church established their congregation under the name "New Chinese Christian Church'. The themes of xenophobia and Western imperialism were the main reasons for local Christians' antagonism towards the missionaries. This new congregation attracted the younger generation of Presbyterians in Shantou and continued to flourish till the I950s (Shantou xinzhonghua jidujiaohui I949).

\section{Conclusion}

Throughout the early twentieth century, China was in perpetual flux, and the views of foreign missionaries and native Christians towards the revolutionary activists, local warlords and Republican authorities changed from time to time. The interaction between Protestant missions and state-building in Chaozhou was as complex as that in other parts of China. On the one hand, the missions contributed to China's modernization and fostered the growth of new social and cultural forces. On the other hand, these new forces were antagonistic towards the missionary enterprises. There was indeed a similarity between the xenophobia of the late-nineteenth-century Confucian scholars and the anti-Christian sentiment of young intellectuals in Republican China.

Another indicator of the growth of national consciousness in the I920s was the efforts of Chinese church leaders to loosen their ties with the missionary societies. The ways in which the Jieyang Presbyterian congregation declared itself an independent church, and in which the Shantou Church controlled its own finance are illustrative. Though 
these local congregations were not always antagonistic towards their denominational heritage, they did not want to run the church according to some rigid regulations imposed by the missionaries. Instead, they combined the Western church model with traditional networks to create the Three-Self church in Chaozhou. If a single lesson emerges from the rapid development of the Chinese Baptist and Presbyterian movements, it is that local Christians established the churches according to their own needs and the new political and social environment, despite all the missionary efforts to shape them in the mold of the Old Christendom.

Faced with the politicization of Chinese society in the I920s, the political and social standing of Protestant missions in the local society did not diminish. The missionaries and Chinese staff expanded their role as educators, modernizers, relief workers and conflict mediators. In addition, the missionaries still benefited from their privileged status under the unequal treaty system. Their role as protectors, mediators and welfare providers was enhanced in times of crises, and the foreign missionary enterprises became what R. Gary Tiedemann (I999; 2004) calls 'a safe haven' for Christians and non-Christians alike. As far as the officials and elites in Chaozhou were concerned, Christianity became an irresistible creed that offered direct access to foreign power, and provided social advancement by means of a modern education at the mission schools. There existed an informal political alliance between the Protestant missions and merchant communities in Chaozhou and Shantou. Once Jiang Jieshi established his control after the Northern Expedition, the national political climate favored the Christian missions. Meanwhile, the Communist forces failed to have a farreaching impact in the I920s. They retreated to the interior and gradually established themselves during the I930s and I940s.

The state - whether it was the late imperial government, local warlords or the Guomindang - was generally perceived by Chinese Christians as beneficial to the modernization of China. In the post-Boxer era, the late imperial state initiated modernizing projects in order to rebuild the country and restore control at the local level. During the I920s, the Guomindang state launched a series of anti-Christian campaigns to foster a sense of unity in the national struggle against imperialism. Its representatives worked closely with pro-government church members and mission school students to challenge the foreign missionary enterprises in Shantou. In the religious sphere, the Guomindang state had successfully intervened in the affairs of foreign mission bodies and local denominational churches. The expansion of state power was part of a broader state-building pattern in early twentiethcentury China, and it increased in frequency in the post-I949 era (Lee 2007b). 


\section{References}

Ashmore, Lida Scott (1920), The South China Mission of the American Baptist Foreign Mission Society: A Historical Sketch of its First Cycle of Sixty Years. Shanghai: Methodist Publishing House.

Band, Edward (1948), Working His Purpose Out: The History of the English Presbyterian Mission, 1847-1947. London: Presbyterian Church of England.

Chen, Chunsheng (I997), 'Baer fengzai suojian zhi minguo chunian Chaoshan qiaoxiang: yi Zhanglin weili [Emigrant Villages and August 2 Disaster in Republican Chaozhou: A Case Study of Zhanglin]'. Chaoxue yanjiu [Chaozhou-Shantou Cultural Research] 6: 369-395.

Chen, Hanchu (comp.) (2004), Zhou Enlai zai Chaoshan [Zhou Enlai in Chaozhou and Shantou]. Beijing: Zhongyang wenxian chubanshe.

China Records Project Miscellaneous Personal Papers Collections, Record Group Number or (RGoI), the George Campbell Papers: series no. I, box I; RGI5, the Ellison and Lottie Hildreth Papers: box 3, folder 28; box 7, folder 94; box II, folder II8; the Yale Divinity School Library, Yale University.

Du, Shimin (2005), 'Erling niandai di jidu jiaohui nüxiao: yi Shantou Shude Nüxiao weili [Christian Girls School in the I920s: A Case Study of the Shude Girls School in Shantou]', unpublished M.A. diss., Shantou University, China.

Dunch, Ryan (200I), Fuzhou Protestants and the Making of Modern China, 1857-1927. New Haven: Yale University Press.

Fitzgerald, John (1996), Awakening China: Politics, Culture, and Class in the Nationalist Revolution. Stanford: Stanford University Press.

Gibson, John Campbell (I90I), Mission Problems and Mission Methods in South China. Edinburgh and London: Oliphant, Anderson and Ferrier.

Eng, Irene and Yi-Min Lin (2002), 'Religious Festivities, Communal Rivalry, and Restructuring of Authority Relations in Rural Chaozhou, Southeast China'. Journal of Asian Studies 6I (4): I259-I286.

Friedman, Edward (I970), 'Revolution or Just Another Bloody Circle? Swatow and the I9II Revolution'. Journal of Asian Studies 29 (2): 289-307.

Galbiati, Fernando (1985), P'eng P'ai and the Hai-Lu-Feng Soviet. Stanford: Stanford University Press.

Gerber, Lydia (2004), 'The Role of German Missionaries in Post-Boxer North China'. Asia Pacific: Perspectives 5 (I): 2I-26.

Guangxuchao donghualu [A Documentary History of the Guangxu Period], vol. 4. Beijing: Zhonghua shuju, I958.

Harrison, Henrietta (200I), China. New York: Oxford University Press.

$\mathrm{Hu}$, Weiqing (2004a), 'Lujing yu kunjing: yi Lingdong zhanglaohui zili yundong wei dianxing ge'an [Route and Predicament: A Case Study of the Self-Independent Movement within the Lingdong Presbyterian Church]', in Liu Jiafeng (ed.), Liyi yi ronghui: Zhongguo Jidutu yu bense jiaohui de xingqi xueshu yantaohui [From Confrontation to Integration: Proceedings of the Conference on Chinese Christians and the Rise of Indigenous Church]. Wuhan: Huazhong shifan daxue.

- $(2004 \mathrm{~b})$, 'Haibin zoulu di guojia rentong: yi Shantou Huaying Xuexiao fengchao wei dianxing ge'an [National Recognition in Chaozhou: A Case Study of the Anti-Christian Movement at the Anglo-Chinese College in Shantou]'. Chaoxue yanjiu [Chaozhou-Shantou Cultural Research] II: 88-т28.

Hood, George A. (1966), 'An Introductory Study of our Missionary “Image”, I847-1965'. The Journal of the Presbyterian Historical Society of England I3 (3): 78-97.

Hood, George A. (I986), Mission Accomplished? The English Presbyterian Mission in Lingtung, South China: A Study of the Interplay between Mission Methods and their Historical Contexts. Frankfurt: Peter Lang. 
Jenkins, Philip (2002), The Next Christendom: The Coming of Global Christianity. Oxford: Oxford University Press.

Lee, Joseph Tse-Hei (2002), 'Christian God and Hostile Communities: Collective Violence in Northeast Guangdong', in Robert James Antony and Jane Kate Leonard (eds.), Dragons, Tigers and Dogs: Qing Crisis Management and the Boundaries of State Power in Late Imperial China, 213-243. Ithaca: East Asia Program, Cornell University.

-(2003a), The Bible and the Gun: Christianity in South China, 1860-1900. New York and London: Routledge.

- (2003b), 'Testing Missionary Archives against Congregational Histories: Mapping Christian Communities in South China'. Exchange: Journal of Missiological and Ecumenical Research 32 (4): 36I-337.

-(2004), 'Church, State, and Community in East Asia: An Introduction'. Asia Pacific: Perspectives 5 (I): I-3.

- (2005), 'Watchman Nee and the Little Flock Movement in Maoist China'. Church History: Studies in Christianity and Culture 74 (I): 68-96.

- (2007a), 'God's Villages: Christian Communities in Late-Nineteenth-Century South China', in Pamela J. Stewart and Andrew Strathern (eds.), Asian Ritual Systems: Syncretisms and Ruptures: 83-II2. Durham: Carolina Academic Press.

- (2007b), 'Christianity in Contemporary China: An Update'. Journal of Church and State 49 (2): 277-304.

Lin, Cunyu (2003), 'Jidujiao bentuhua jincheng ji fangshi” yi Shantou shi Yanzao xiang weili [The Indigenization of Christianity: A Case Study of Yanzao Village in Shantou]'. Shantou daxue xuebao [Journal of Shantou University] 19: II8-I23.

Liu Yihui (2003), 'Liu shi jiapu xiaodian: Chaoshan jidujiao bentuhua shiliao juyu [Commentaries on The Family Genealogy of the Liu: Sources on the Indigenization of Christianity in Chaozhou-Shantou]'. Shantou daxue xuebao [Journal of Shantou University] I9: II5-II7.

Mahoney, Irene (1996), Swatow: Ursulines in China. New York: Graphics/Print Production.

Murdock, Michael G. (2000), 'Poor Man's Anti-Imperialism? The Anti-Christian Movement and the Political Value of Cultural Targets for Revolutionary Activity, August 1924-June I925'. Journal of the History of Christianity in Modern China 3: 60-8I.

- (2002), 'Dual-Prong Revolution: Guomindang Use of Agitation and Accommodation against Missionary Education during the mid-I920s', in Terry Bodenhorn (ed.), Defining Modernity: Guomindang Rhetorics of a New China: II-44. Ann Arbor: Center for Chinese Studies, University of Michigan.

-(2006), Disarming the Allies of Imperialism: Agitation, Manipulation, and the State during China's Nationalist Revolution, 1922-1929. Ithaca: East Asia Program, Cornell University.

PCE. Presbyterian Church of England Archives, Foreign Mission Committee (FMC) on China, series I, box 3I, folder 7; series I, box 42B, folder IO; FMC on China, microfiche no. 640 , no. 654 , no. 793 , no. 798 and no. 874; the Library of the School of Oriental and African Studies, University of London.

Sanneh, Lamin (2003), Whose Religion is Christianity? The Gospel beyond the West. Grand Rapids: William B. Eerdmans Publishing Company.

Stanley, John R. (2004), 'Mission Education as a Community Effort in Early Twentieth-Century North China'. Asia Pacific: Perspectives 5 (I): 27-32.

Thøgersen, Stig (2002), A County of Culture: Twentieth-Century China Seen from the Village Schools of Zouping, Shandong. Ann Arbor: University of Michigan Press.

Shantou xinzhonghua jidujiaohui [New Chinese Christian Church of Shantou] (comp.) (I949), Shantou xinzhonghua jidujiaohui ershi zhounian jinian tekan [Special Issue on the Twentieth Anniversary of the New Chinese Christian Church in Shantou]. Shantou.

Tiedemann, R. Gary (I99I), 'Rural Unrest in North China I868-I900: With Particular Reference to South Shandong', unpublished Ph.D. diss., University of London. 
—(1999), 'China and its Neighbors', in Adrian Hastings (ed.), A World History of Christianity: 369-4I5. Grand Rapids: William B. Eerdmans Publishing Company.

- (2004), 'THEY ALSO SERVED! Missionary Interventions in North China, I900-I945', in Tao Feiya and Philip Yuen-Sang Leung (eds.), Re-interpreting the East Asian Christianity: I55-190. Hong Kong: Centre for the Study of Religion and Chinese Society, Chinese University of Hong Kong.

Wang, Gungwu (2003), Anglo-Chinese Encounters since 1800: War, Trade, Science, and Governance. Cambridge: Cambridge University Press.

Wang, Linqian and Wu Kunxiang (comp.) (2003), Xinhai geming Chaoshan geming huidong zhiliao [Historical Materials on the Revolutionary Activities in Chaozhou and Shantou in 1911]. Shantou: Chaozhou-Shantou Cultural Research Center.

Wei, Zhiyuan (1949), 'Yanzao tanghui bainian shilue [An Overview of the History of Yanzao Congregation]', in Yanzao tanghui bainian jiniankan [Special Issue on the Hundredth Anniversary of the Yanzao Congregation]: I-4. Yanzao, Chenghai District, Guangdong Province.

Yip, Ka-Che (1980), Religion, Nationalism, and Chinese Students: The Anti-Christian Movement of 1922-1927. Bellingham: Center for East Asian Studies, Western Washington University.

-(I982), 'Student Nationalism in Republican China, I9I2-1949'. Canadian Review of Studies in Nationalism IX (2): 247-26I.

- (2003), 'China and Christianity: Perspectives on Missions, Nationalism, and the State in the Republican Period, I9I2-I949', in Brian Stanley (ed.), Missions, Nationalism, and the End of the Empire: I32-I43. Grand Rapids: William B. Eerdmans.

Yu, Anthony C. (2003), 'On State and Religion in China: A Brief Historical Reflection'. Religion East and West 3: I-20. 



\title{
5 The Structure of Salt Distribution in Taiwan, 1895-1945
}

\author{
Tsu-yu Chen
}

\section{Introduction}

Salt is a commodity necessary for daily life. There are salt resources all over the world, yet not every region can produce table salt. A common way to produce salt is by evaporating seawater. Taiwan is well suited for this kind of activity. Retrieving salt from seawater started in Taiwan very early since the island was inhabited.

Before 1895 the Taiwanese salt trade was part of the Chinese salt trade. Since the second century B.C.E. the right to salt distribution belonged exclusively to the Chinese government and to licensed merchants. Over time, there emerged a complex structure for the distribution of salt and a series of salt laws.

Salt distribution has attracted attention from historians (Liu 1989: 608-609, 6I7-623), but research on the Taiwanese salt trade is rather

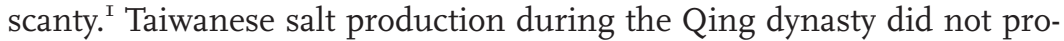
vide self-sufficiency for Taiwan, nor did Taiwan play an important role in the Chinese salt trade network. Before the twentieth century, local governments paid attention only to the local distribution of salt. In the twentieth century, in order to increase revenues, Japanese colonial authorities started promoting new production techniques and development of a distribution network according to the policies formulated under the slogan, 'chemical industries in Japan, raw materials and salt from Taiwan.' In the late I930s the Japanese government decided to develop chemical industries in Taiwan on the basis of local salt production facilities. Salt and its by-products became the raw materials of a nascent chemical industry. Thus salt provided a link to modern industrial science and technology.

This article describes the process of establishing the salt monopoly and the formation and development of its marketing network in order 
to analyze the transformation of the Taiwanese salt trade from importsubstitution to export-oriented industry.

\section{The establishment of the table salt monopoly}

\section{Background}

After Japanese colonial rule was set up in Taiwan in I895, a new Government-General was established to administer the island. The regulations from 1896 , especially paragraph $6_{3}$, gave the Government-General very broad powers: 'the Government-General of Taiwan in the territory under his jurisdiction promulgates decrees with legal force' (Taiwan sōtokufu I92I: 2). The official orders of the Government-General had binding legal force. ${ }^{2}$

Taiwanese colonial authorities considered re-establishing a salt monopoly in Taiwan. Draft regulations stressed that Taiwanese salt was not sufficient to meet the needs of the local population. After consultations between the Ministries of Interior Affairs, Foreign Affairs, Agriculture and Commerce, the Ministry of Agriculture and Commerce finally allowed the Taiwanese local authorities to re-establish the salt monopoly. On April 20, I899 the Japanese prime minister in an official letter to the Taiwanese Governor-general Kotama Gentarō stressed the conditions under which the Japanese government would permit the Taiwanese salt monopoly to be established:

I. It is forbidden to purchase Chinese salt and resell it in Japan.

2. If there is a shortage of local salt in Taiwan and it is necessary to import it from China, such salt imports need to be reported in advance to the Interior Affairs Ministry and to the Agriculture and Trade Ministry.

3. Because foreign salt is imported to Japan only after the payment of custom taxes, Taiwanese salt transported to Japan has to be sold at current market prices (Taiwan sōtokufu shenbaisenbaikyoku i924b: 34-37).

The fact that Kotama decided to press Tokyo about permission for a local salt monopoly had much to do with the head of the Taiwanese Civil Affairs Department Gotō Shimpei. Immediately after taking office, he employed the services of $\mathrm{Gu}$ Xianrong. ${ }^{3} \mathrm{Gu}$ proposed the idea of re-establishing the salt monopoly to Gotō:

The Qing dynasty officials and literati were the most powerful local figures, but after Japan took over Taiwan all previous titles became useless, and when their power was lost they encountered many hardships. If the new authorities showed benevo- 
lence towards the subjects and restored the salt monopoly privileges to local elites, it would help greatly to improve local order. ${ }^{4}$

Gotō Shimpei agreed with the proposal (Tsurumi I943: 285-287)..$^{5}$

In addition to $\mathrm{Gu}$ Xianrong's suggestions, the success of the opium monopoly in Taiwan also helped to convince local Taiwanese authorities to re-establish the salt monopoly. The rules of the salt monopoly were in fact based on the rules of the opium and camphor monopolies (Takegoe I985: 273). According to those rules, the Monopoly Bureau employed a salt trade supervisor and a supplementary supervisor; both salaried and wearing specially designed uniforms (Taiwan sōtokufu I926).

Financial problems faced by the new colonial authorities in Taiwan were also among the reasons leading them to re-establish the salt monopoly. Government funding from Japan was cut from seven million to four million yuan. Kotama Gentarō and Gotō Shimpei had to find new financial resources for their administration (Yanohara I985: 9). And the fact that a salt monopoly had existed in the past made reintroducing this institution much simpler.

The main reason for re-establishment of the salt monopoly was to increase revenues for the colonial authorities and to pay the costs of governing Taiwan from local resources. Revenues from the government monopolies accounted for 40-50 per cent of the colonial government's general revenues. The revenues from the salt monopoly were always a stable part of revenues derived from all government monopolies, constituting 3 to Io per cent of total revenues. In comparison, opium monopoly revenue was 78 per cent of total monopolies' revenues in I899, but gradually fell to only I per cent in I943. After I924 cigarette and alcohol monopolies provided most of the monopoly revenues, up to 94 per cent in I943 (Chen 1991: 594-598).

As I will explain in more detail later, the salt monopoly was also helpful in controlling social behavior; Japanese authorities used it as a tool for social control.

Another reason for re-establishing the salt monopoly was that it helped the colonial authorities to cut the economic links that had bound Taiwan and Mainland China and to promote economic exchange between Taiwan and Japan. The rules of the Taiwanese salt monopoly were published in the Imperial prescript no. 5I regulating the structure of the Taiwanese Salt Affairs Bureau, in law no. 7 concerning the activities of the salt monopoly, and in law no. I4 governing the structure of salt fields (Linji Taiwan kyukan chōsakai I985: 274). The Taiwanese Salt Affairs Bureau was subordinate to the office of the Government-General and was in charge of salt purchasing and subsequent marketing, and the investigation of market conditions. The Tai- 
wanese Government-General decided the position of the Taiwanese Salt Affairs Bureau in the administrative structure and its competences. In April I899, 20 Salt Affairs Bureau branches were established all over the island (Taiwan sōtokufu shenbaisenbaikyoku i924b: 597-598).

\section{Establishment of the salt monopoly}

The main rules of the Taiwanese salt monopoly were proposed in a draft by the Tax Office on June 8, 1898 , approved by the governor in July and promulgated by law no. 7 on April 26, I899 (Ishinaga 1942: 93-94). Government decree no. 34 from April I899 decided that the salt monopoly would start operating on May I5, I899 (Taiwan sōtokufu shenbaisenbaikyoku shomuka I9II: 804). Detailed Regulations were also issued in April of that year in decree no. 32. Paragraph no. 4 of the Detailed Regulations added that the officials responsible for inspection of salt fields and storehouses should carry their ID cards when on an inspection tour (Taiwan sōtokufu shenbaisenbaikyoku I924a: I-2).

Under the salt monopoly system the production of salt in Taiwan rose significantly. The domination of big salt companies in the total salt production enabled officials to take efficient control of the process.

In May I90 imperial prescript no. II6 established the Monopoly Bureau of the Taiwan Government-General, which joined the Taiwan Salt Affairs Bureau and the Taiwan Camphor Bureau into one administrative structure. In June of that year the Taiwan Salt Affairs Bureau officially ceased to exist (Taiwan shenbaisenbaikyoku I94I: 658-659). The Taiwanese salt monopoly was re-established to increase administrative revenues. The scope of the monopoly's responsibilities was gradually increased, enabling colonial authorities to control the salt industry.

\section{Establishment of the local marketing structure}

The Taiwanese salt monopoly started operating in I899 and was administered by the Salt Affairs Bureau. The bureau was responsible for purchases of local salt as well as for imports of foreign salt. The location of all the bureaus and their responsibilities are listed in table 5.I.

The most difficult task facing the new local authorities in Taiwan was that they were not familiar with existing marketing networks. They also lacked experience in salt transportation. The Japanese did not know local customs regulating salt trade, nor did they know the local language. Facing these problems, the Japanese authorities decided to employ the services of local elites to build the foundation of the distri- 
Table 5.1 Organization and functions of the Taiwan Salt Affairs Bureau in 1899

\begin{tabular}{|c|c|}
\hline Office Location & Responsibilities \\
\hline Jilong, Danshui, Houlong, Lugang & Purchases of local salt \\
\hline Budaizui, Beimenyu, Tainan, Dagou & $\begin{array}{l}\text { Imports of foreign salt and purchases of } \\
\text { local salt }\end{array}$ \\
\hline Xinzhu & Retail sales of salt \\
\hline Taibei, Danshui, Jilong, Xinzhu, Houlong, & Twenty branches of Taiwan Salt Affairs \\
\hline $\begin{array}{l}\text { Dajia, Taizhong, Lugang, Pulishe, Yunlin, } \\
\text { Jiayi, Budaizui, Beimenyu, Tainan, Fengshan, } \\
\text { Dagou, Hengchun, Yilan, Taidong, Penghu } \\
\text { Islands }\end{array}$ & Bureau to take care of local affairs \\
\hline
\end{tabular}

Source: Linji Taiwan kyukan chōsakai (1985): 275-276. The wholesale salt system

bution network of the monopoly (Linji Taiwan kyukan chōsakai I985: 275-276).

As a reward for their services, the local elites were given rights for the wholesale marketing of salt. Gu Xianrong was able to profit from this enormously, because of his close relations with the new authorities. The Japanese hoped to win the loyalty of the Taiwanese gentry, and in order to foster their cooperation gave them privileges in the salt monopoly structure. The Monopoly Bureau in I902 had a staff of one bureau chief, nine general affairs officials, six engineers, three translators, clerks, technicians, and interpreters; a total of I44 persons. In addition to a headquarter in Taipei, the bureau operated branches in Jilong, Huwei, Youchegang, Houlong, Lugang, Beimenyu, Budaizui, Tainan, Dagou, Miaoli, Taizhong and one branch in Kobe, Japan (Linji Taiwan kyukan chōsakai i985: I45).

The distribution structure of the salt monopoly experienced three main adjustments:

\section{a. The system of four steps (April 1899 - March 1905)}

After establishing a syndicate for salt sale in Taipei, several merchants set up general offices and branch offices around hub locations in Taiwan. The salt flow processes were as follows:

Government - Headquarters of salt sale syndicate - General office Branch office - Retail merchants - Consumers.

The chairman of the syndicate was Gu Xianrong. He selected investors (Taiwan sōtokufu shenbaisenbaikyoku I924b: I93-222; Taiwan sōtokufu I899). Gotō Shimpei's teacher was appointed as the advisor to the syndicate. Li Bingjun and Wang Qingzhong became vice-chairmen; Chen Luo and Liu Tingyu became supervising directors (Gu I939: 8990). There were also over 700 brokers called 'middle merchants', who linked Salt branch offices with retailers. The general office paid a se- 
curity deposit to the headquarters of the salt sale syndicate, and the branches paid security deposits to the general office.

The system of three steps (April 1905 - July 1926)

To simplify the organization and secure the profits from salt sales more directly, in April I905, the government disbanded the syndicate and set up a general office for sales of salt. Gu Xianrong was the chairman of the general office (Taiwan sōtokufu shenbaisenbaikyoku i924b: 222-256). After I9I6, the Organization for the Sale of Refined Salt was founded. This organization was controlled by several Japanese merchants; in I920 it was replaced by the Taiwan Salt Production Company (TSPC). ${ }^{6}$ The Monopoly Bureau had six branches, located in Shengyouchegang, Lugang, Budaizui, Beimenyu, Tainan and Wushulin. The branches in Lugang and Budaizui were the biggest wholesalers. The branches in Budaizui and Beimenyu were mostly responsible for salt export (Taiwan sōtokufu shenbaisenbaikyoku ig24b: 222-256). The three step system was as follows:

Chart 5.1 The three step system

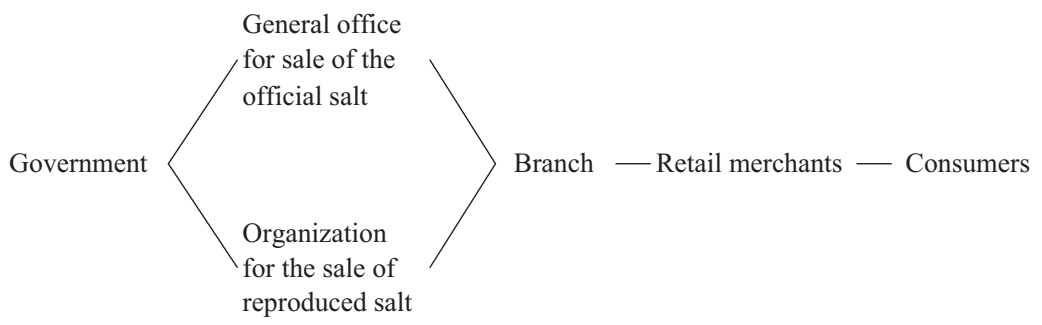

c. The system of two steps (August 1926 - August 1945)

Because of rich salt production and convenient transportation for salt distribution, the General Office and the Organization were both abolished after August I926. Gu Xianrong and the TSPC were appointed as salt deliverers and took all transportation rights. The chairman of the branch office became the wholesaler. The circulation of reproduced salt ('special salt') followed a different system. The process of the twostep system was as follows (Taiwan sōtokufu I926; Zhang I955: 9): 
Chart 5.2 The two step system

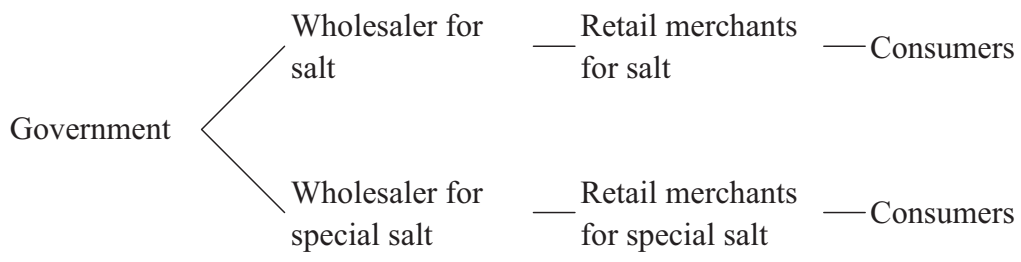

Salt was transported by the General office (wholesaler) during the periods in which the four-step and three-step systems were used (April I899-July I926), then wholesalers might directly sell or distribute to branches. After the two-step system, Gu Xianrong and the TSPC delivered all the salt (Chen I993: 46). The government decided the salt prices in the circulation process.

The table salt distribution network experienced three main reorganizations. A big change was also taking place in the number of salt retailers. On August I, I926 the Official Salt Wholesale Main Office was abolished and its local branches were changed into privately run wholesale firms (Fujuzaki ı985: 156).

Table 5.2 Changes in salt distribution network in Taiwan (1915-1944)

\begin{tabular}{llll}
\hline Year & $\begin{array}{l}\text { Official Salt Wholesale } \\
\text { general offices }\end{array}$ & Salt branch offices & Retail merchants \\
\hline 1915 & 1 office & 82 offices & 3,934 people \\
1916 & 1 office & 83 offices & 4,080 people \\
1924 & 1 office & 86 offices & 2,623 people \\
1926.8 & Refined salt wholesale & Table salt wholesale & Table salt retail merchants \\
& merchants & merchants & \\
1931 & 16 people & 85 people & 2,095 people \\
1934 & 16 people & 83 people & 2,310 people \\
1936 & no information available & 75 people & 2,185 people \\
1937 & 12 people & 75 people & 2,615 people \\
1938 & no information available & 75 people & 2,629 people \\
1940 & no information available & 75 people & 2,658 people \\
1942 & 6 people & 69 people & 3,081 people \\
1943 & no information available & 69 people & 2,947 people \\
1944 & no information available & 69 people & 3,044 people \\
\hline
\end{tabular}

Source: Zhang Xiuwen 1955:9; Taiwan sōtokufu shenbaisenbaikyoku 1936: 23-29; Taiwan sōtokufu 1985: 469 .

Table 5.2 shows that salt distribution channels were constantly being reduced, presumably to decrease abuses and illegal profiteering. Moreover, the control of these distribution channels became increasingly centralized. Wholesale merchants decreased in numbers, but the num- 
ber of retail salt merchants increased. Wholesalers were also gradually replaced by the Japanese, and the role for native Taiwanese in the salt trade was increasingly limited to retailing.

In July I905, 70 people were appointed as managers of Official Salt Wholesale General Offices. Twelve of them were Japanese, the others Taiwanese. However, in time Japanese control of the office increased (Taiwan sōtokufu shenbaisenbaikyoku shomuka I9II: 843-847). In I94I out of 75 salt wholesale merchants working for the Taiwan Monopoly Bureau, only I2 were Taiwanese and all others Japanese (Taiwan sōtokufu shenbaisenbaikyoku shomuka I9II: 843-847). Who were those Taiwanese that managed to obtain a salt wholesale license? One example is Jian Langshan. He had served in the Japanese army headquarters at the beginning of Japanese rule in Taiwan. Afterwards he was bestowed the honor of the sixth grade and became a member of the council of the Taiwan Government-General. In addition, he served as the chairman of the board of the Taoyuan Railway Company, and as director of the board of the Japanese Development Company (Taiwan sinminpōsha 1937: 64; Lin I933: 33). Another example is Peng Songshou, a member of the Miaoli City Council and a board director in the Miaoli Credit Union (Lin 1933: 20-2I; Kōnan sinbunsha 1947: 357). Lin Mugen, once a public school teacher, became an entrepreneur, engaged in the cement trade and obtained a license for the wholesale of opium. He was also a member of the Jiayi City Council, a vice president of the Jiayi Commercial Association and a head of the southern office of Shuwa News. In 1936 he was appointed as a Tainan area councillor (Lin I933: III; Taiwan sinminpōsha I947: 468-i69). These examples show that the Japanese authorities used Taiwanese supporters, but placed their own nationals in the top administrative positions. The salt monopoly was very attractive to men coming from Japan for good jobs in the colonial government, but the salt monopoly was also used to win over the support of influential Taiwanese.

\section{The unification of salt production and distribution}

In the beginning of the salt monopoly, the colonial authorities encouraged people to restore old salt fields and to establish new ones. Both Taiwanese and Japanese capital was invested in these salt fields. Table 3 lists the names of those investors who obtained special permits from the Government General to set up salt fields.

Table 5.3 shows that $\mathrm{Gu}$ Xianrong of the General office and Chen Zhonghe of the branch office in Dagou invested in salt production in central and southern parts of the island. Chen Zhonghe worked for Chen Fuqian's family.7 In 1873 he shipped 5,000 bags of cane sugar to 
Table 5.3 Holders of special permits for salt production (1903)

\begin{tabular}{llrc}
\hline Salt producer & Location of salt field & $\begin{array}{l}\text { Field size } \\
\text { (ha) }\end{array}$ & $\begin{array}{l}\text { Salt field productivity } \\
(\mathrm{kg} / \mathrm{ha})\end{array}$ \\
\hline Nozaki & Budaizui & 79.20 & 146,667 \\
Gu Xianrong & Lugang & 86.13 & 139,394 \\
Gu Xianrong & Youchegang & 21.78 & 127,273 \\
Asano & Dagou & 69.30 & 72,727 \\
Chen Zhonghe & Dagou & 49.50 & 72,727 \\
Tu Jiancheng & Beimenyu & 49.50 & 165,455 \\
20 other people & (various) & 288.09 & \\
\hline
\end{tabular}

Source: Ishisaka Sōsaku 1985: 54.

Japan and then stayed there for some time to conduct business before returning to Taiwan. After Chen Fuqian died, Chen Zhonghe established his own business (Zhao I985: 4-10). During the Russo-Japanese war, Chen and $\mathrm{Gu}$ Xianrong collaborated on Japanese military defence. They dispatched ten junks and bamboo rafts to guard the Taiwan Straits. When 38 Russian vessels were noticed, they immediately reported it to Japanese colonial authorities. This intelligence helped Japan to defeat Russia (Sima I987: I76-I80). Those events illustrate the close ties between Chen Zhonghe and the Japanese.

In I90I, Chen Zhonghe became a manager of the southern General Office of Salt, and four years later he took charge of Dagou Salt branch (Zhao I985: 24). He used these positions to further the activities of his salt producing company. In March I922 Chen set up the Natural Resources Company, as a family business with I.2 million yen of capital (Okata I94I: 43I).

In addition to running a sugar business using new production techniques, Chen also set up a salt production company in Yongan Township of Gaoxiong County. The company originally possessed only salt fields. In I923 the firm reorganized into Wushulin Company with Chen as its president. In addition to salt production, the firm was also involved in fish farming and the construction of railway tracks (Miyazaki I931: 29).

By the I930s, the development of the salt industry in Taiwan was tied to Japanese military aggression, as Taiwan became the base of Japan's activities in Southeast Asia. The colonial government encouraged the salt-producing enterprises to mass-produce salt, which was needed by the growing chemical industry in Taiwan. After the outbreak of the Sino-Japanese War in I937, the Japanese government drew up a program to further increase salt production for industrial use. In addition to developing salt farms in the occupied north-eastern and northern regions of China, Japanese zaibatsu founded Minami Nihon Yengyō Kaisha (Southern Japanese Salt Industry Company) in central Taiwan 
in 1938 (capitalized at to million yen) to develop salt farms for industrial use and for production of bromine. Nihon Soda Co., Nihon Yengyō Co., and Taiwan Takushoku Co. (Taiwan Development Co.) invested in Minami Nihon Kagaku Kōgyō Kaisha (Southern Japanese Chemical Industrial Co.) in southern Taiwan. The new company produced and sold chemical industrial materials and products, medicines, dyes, paper fiber, and also managed mining and metallurgical industries. The salt industry in Taiwan was monopolized by TSPC and Southern Japanese Salt Industry Company, and was thoroughly transformed into a modern industry, coordinating with the Southern Japanese Chemical Industrial Company. Additionally, the Kanewuchi Soda Co. was founded in 1942 and capitalized at to million yen (Zhang I955: I3).

In I944, the area of salt farms reached 6,543 hectares, three times more than fifteen years before, and I8.5 times more than 45 years before. The TSPC owned 30 per cent of the farms and the Southern Japanese Salt Industry Company owned 40 per cent.

\section{The development of external markets}

Before the Japanese occupation, Taiwan had to import salt from Mainland China. At the beginning of Japanese rule, Japanese residents used salt that was imported from Japan. But after the Japanese government implemented the policies of the 'Japanese Salt Industry Empire' (including Japan and her colonies), Taiwanese salt shipments to Japan were officially encouraged and promoted.

\section{Main external markets}

Exports of Taiwanese table salt began in September 1899 to Japan. Japanese officials managed shipments of Taiwanese salt and its import to Japan. Kurihara Tomijiro, a salt wholesaler from Aichi prefecture, was exclusively responsible for the distribution of Taiwanese salt in Japanese markets (Ishinaga 1942: 227). As of 1907, the Japanese Monopoly Bureau directly arranged imports of Taiwanese salt to Japan, and Kurihara was only contracted as a wholesaler for salt distribution. The government assigned 3,000,000 yen to establish the Tōyō (Orient) Salt Industry Company and to take over the responsibility for salt distribution in the Japanese market from Kurihara in I909. The Tōyō Salt Industry Company changed its name to the Taiwan Salt Industry Company the following year. The firm was merged with the Great Japan Salt Industry Company in I9I7. From then on, the Great Japan Salt In- 
dustry Company held a monopoly on Taiwanese salt imports (Zhang I955: I0).

The goal of importing Taiwanese salt to Japan was originally to substitute it for European salt, which Japan imported in large quantities (Kozawa 2000: 194-196). That is why the import of Taiwanese salt immediately became very significant, as indicated in table 5.5.

Salt imports from Taiwan quickly increased, mainly because wages of workers in Japan increased, which raised the cost of production and the price of Japanese salt. Meanwhile the quality of Taiwan salt was quickly improved.

Because of its climate and environment Japan was not able to produce salt using the technique of evaporation of sea water under the sun. Instead, salt was produced mainly with the technique of boiling saline water; therefore, the production costs were higher than those of imported dried salt (Kozawa 2000: II6-II7).

In the past, trade between Taiwan and Japan had been conducted under export-import rules, but after the island came under Japanese rule trade became 'domestic', and many trade barriers, such as custom duties, diminished or disappeared (Yao I977: 5I-60). At first, the quality of Taiwanese salt was lower than Japanese consumers were willing to accept, so the sales volume was small. But as Taiwanese colonial authorities encouraged production of better quality salt, the sales of local salt on the Japanese market increased, as table 5.4 shows (Takegoe I985: 280).

After the outbreak of the Russo-Japanese war, the most urgent task for the Japanese government was to increase military expenditures. Thus, in June 1905 the Salt Monopoly Law was promulgated to increase government revenues and protect the domestic salt industry from competition (Kozawa 2000: II4). As the war ended, salt from the Liaodong Peninsula started to be imported into Japan. The monopoly converted the price difference between cheap Taiwanese and Liaodong salt and the Japanese salt into profits that increased government revenues. In I9I0-I9II the Japanese government conducted the first series of local salt field consolidations in order to diminish the costs of domestic salt production. The fields with the highest production costs were closed down and decreased domestic salt production was covered by imports (Kozawa 2000: I22-I26). As indicated in table 5.4, salt imports grew in the first decades of Japanese rule in Taiwan.

In particular, World War One presented Taiwan with a big opportunity to develop its salt industry. As tables 5.4. and 5.5. show, after Japan entered the war in I9I4, its imports from Taiwan sharply increased.

Table 5.5 indicates that during the first three years of the Taiwanese salt monopoly, Japan became its main market and the volume of sales in Japan exceeded domestic sales in Taiwan. After Japan occupied and 
Table 5.4 Japanese salt supply and demand (Unit: 10,000 tons)

\begin{tabular}{|c|c|c|c|c|c|c|c|}
\hline \multirow[t]{3}{*}{ Year } & \multicolumn{6}{|l|}{ Salt Supply } & \multirow{2}{*}{$\begin{array}{l}\text { Salt } \\
\text { Demand }\end{array}$} \\
\hline & Domestic & Imported & Salt & & & Total & \\
\hline & Kandoshu & Taiwan & Qingdao & $\begin{array}{l}\text { Sum of } \\
\text { Imports }\end{array}$ & & & \\
\hline 1905 & 33.28 & 0.70 & 2.50 & 0 & 3.95 & 37.23 & 37.19 \\
\hline 1906 & 56.48 & 1.14 & 2.61 & 0 & 4.18 & 60.66 & 60.61 \\
\hline 1907 & $59 \cdot 34$ & 7.24 & 3.43 & o & 4.67 & 64.02 & 63.27 \\
\hline 1908 & 62.28 & 2.49 & 1.62 & o & 4.46 & 66.74 & 60.68 \\
\hline 1909 & 59.70 & 2.40 & 3.04 & O & 5.67 & 65.37 & 61.15 \\
\hline 1910 & 56.77 & 1.98 & 3.35 & o & 5.37 & 62.14 & 60.55 \\
\hline 1911 & 56.95 & 2.76 & 3.78 & 0 & 7.59 & 64.55 & 68.57 \\
\hline 1912 & 62.01 & 2.15 & 3.13 & o & 5.28 & 67.28 & 67.01 \\
\hline 1913 & 64.00 & 3.84 & 3.64 & o & 7.48 & 61.48 & 72.28 \\
\hline 1914 & 61.09 & 4.92 & 5.62 & 0 & 10.54 & 71.63 & 71.03 \\
\hline 1915 & 59.72 & 3.56 & 5.43 & o & 8.99 & ור.78. & 69.17 \\
\hline 1916 & 62.05 & 4.94 & 6.37 & o & 11.32 & 73.37 & 73.98 \\
\hline 1917 & 60.24 & 10.21 & 9.23 & 3.70 & 23.25 & 83.49 & 82.16 \\
\hline 1918 & 40.32 & 9.48 & 7.7 & 16.42 & 35.75 & 76.07 & 76.80 \\
\hline 1919 & 58.90 & 8.49 & 2.29 & 21.01 & 52.60 & 111.51 & 99.76 \\
\hline 1920 & 54.40 & 8.84 & 1.31 & 15.23 & 37.87 & 92.27 & 73.46 \\
\hline 1921 & 51.51 & 8.02 & 4.47 & 11.43 & 26.09 & 77.60 & 80.26 \\
\hline 1922 & 66.50 & 8.05 & 5.77 & 10.09 & 29.96 & 96.47 & 86.75 \\
\hline 1923 & 47.99 & 12.96 & 7.47 & 0.49 & 22.74 & 70.73 & 80.80 \\
\hline 1924 & 63.72 & 14.80 & 10.96 & 0 & 32.13 & 95.85 & 81.65 \\
\hline 1925 & 66.86 & 10.22 & 6.83 & 0 & 21.72 & 88.59 & 82.78 \\
\hline 1926 & 61.41 & 7.04 & 5.49 & 6.85 & 24.14 & 85.55 & 85.98 \\
\hline 1927 & 61.91 & 4.56 & 4.49 & 13.09 & 24.01 & 85.93 & 87.46 \\
\hline 1928 & 63.79 & 5.91 & $4 \cdot 54$ & 16.43 & 28.13 & 91.92 & 90.17 \\
\hline 1929 & 64.42 & 8.15 & 5.18 & 19.97 & 33.55 & 97.97 & 97.73 \\
\hline 1930 & 62.87 & 15.30 & 8.24 & 12.50 & 37.32 & 100.19 & 94.35 \\
\hline 1931 & 52.13 & 18.90 & 10.11 & 9.83 & $45 \cdot 42$ & 97.54 & 107.21 \\
\hline 1932 & 57.26 & 14.72 & 8.33 & 13.58 & 63.84 & 121.10 & 120.45 \\
\hline
\end{tabular}

Source: Kozawa Tokio 2000: 127.

subsequently obtained leasing rights to Qingdao as a result of World War One, Qingdao salt started arriving in Japan. The result of the economic boom during the war and increasing wages led to increased salt production costs and closures of many salt factories in Japan. This situation resulted in a sharply diminished supply of salt in Japan, amounting to the supply levels were cut in half of the domestic production in I9I7-I9I8. Facing this impasse, the Japanese government ordered the import of additional salt from Liaodong, Qingdao and Taiwan. Most of the salt imports came from Taiwan (Ishinaga I942: 232; Tanaka I985: 57-58). 
The Japanese government's objective was to keep domestic salt as a basic supply source of table salt for consumers and to turn cheap imported salt into a raw material for the Japanese industry. The imported salt was mostly used for further processing (refined salt) and for the food industry. As table 5.5. indicates, because Taiwanese salt was the cheapest and its supply volume the biggest, the Taiwanese salt monopoly was still very profitable. Taiwanese competition forced the Japanese government to implement a second wave of domestic salt field eliminations during I929 and I930 to get rid of the least efficient producers. Due to these efforts, in I93I Japanese salt production further decreased to 87.2 per cent of the I928 level (Kozawa 2000: I26-I29). The abrupt increase of Taiwanese salt imports in I93I was caused by the closures of domestic salt fields. The sharp increase in Taiwanese salt imports after I935 was linked to the second Sino-Japanese War. The developing Taiwanese chemical industry increased the local demand for salt, but big industrial salt fields were simultaneously opened. Production of salt from those new fields was sufficient to meet the growing local demand and significant growth of exports to Japan. From I939 until I942, continued development of the Taiwanese chemical industry further increased local salt demand and caused constraints on the supply side. Exports to Japan diminished by nearly half.

Taiwan also started exporting salt to Korea, Sakhalin, the Russian Far East, Hong Kong and Manila (Ishinaga I9I6: 42I). Due to shortages of domestic salt in Korea, salt had been formerly imported from Japan. Most salt entered Korea through the port of Pusan. After the Sino-Japanese War of I894-95, Chinese dried salt started being shipped to the Korean northwestern coast, and the volume of this trade increased very quickly. In I896 Korea imported only I20,000 kilograms of salt from China (I per cent of all salt imports); in I903 it imported I2,300,000 kilograms of salt from China (66.7 per cent of all salt imports). Chinese salt was easily substituted for Japanese salt because of its low price. Korean and Japanese salt was sold at 4.37 yen for one hundred catties while Chinese salt was priced at only I.I6 yen (Tanaka I996: 478-48I).

In I903, Japanese merchants imported 90,000 kilograms of Taiwanese salt to Korea through Pusan. In I908 the amount of Taiwanese salt increased to 9,300,000 kilograms. Competition from Shandong salt drove Taiwanese salt out of the Korean market after I9I3. In I923, the salt imported from Liaodong and Shandong decreased, and Taiwanese salt reappeared on the Korean market. But when in I928-I929 Chinese salt exports to Korea again increased, imports of Taiwanese salt immediately decreased. In I930 Korean colonial authorities implemented regulations, which declared how much Taiwanese salt should be imported each year. Thus, the import of Taiwanese salt to Korea was 


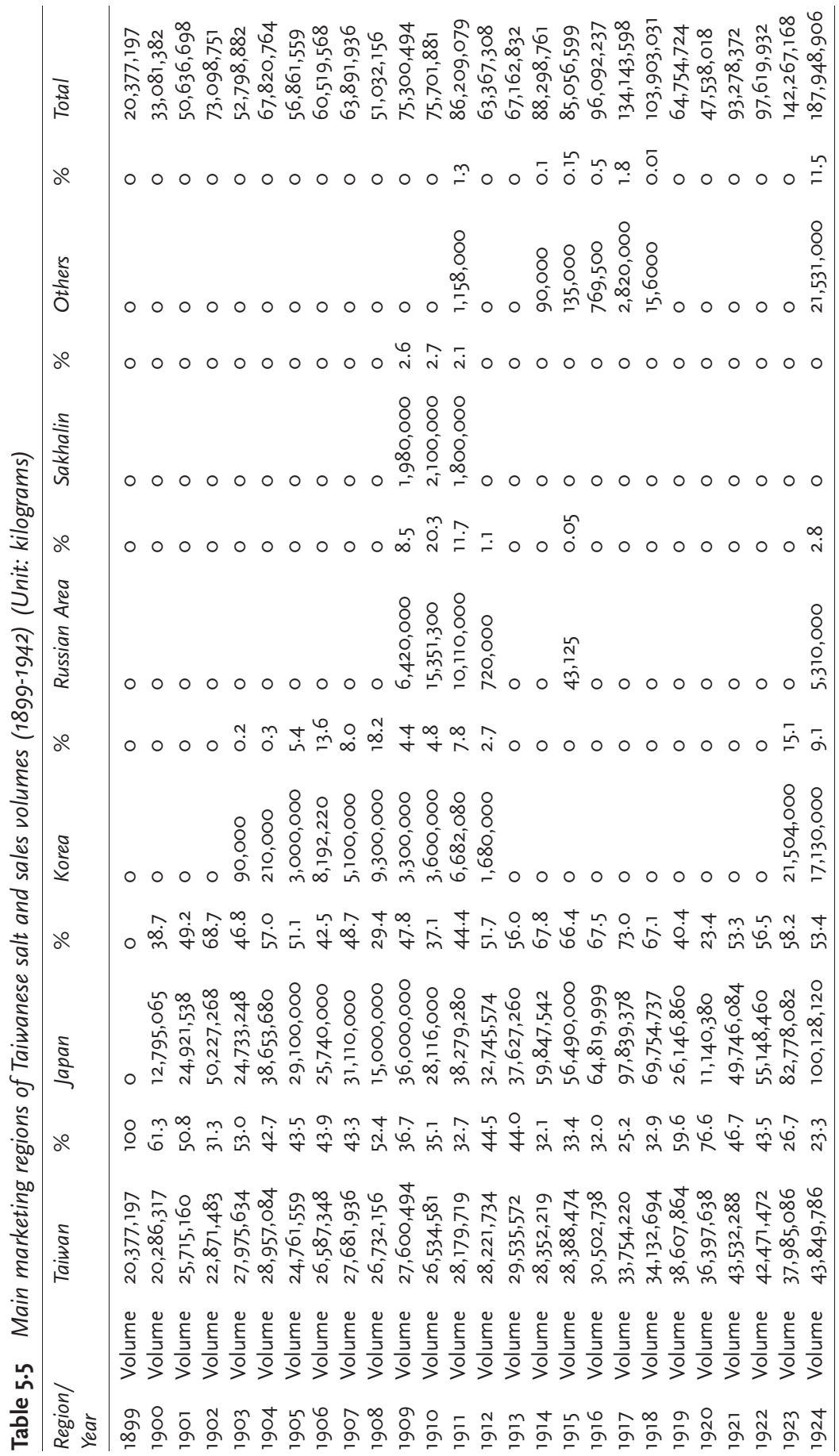




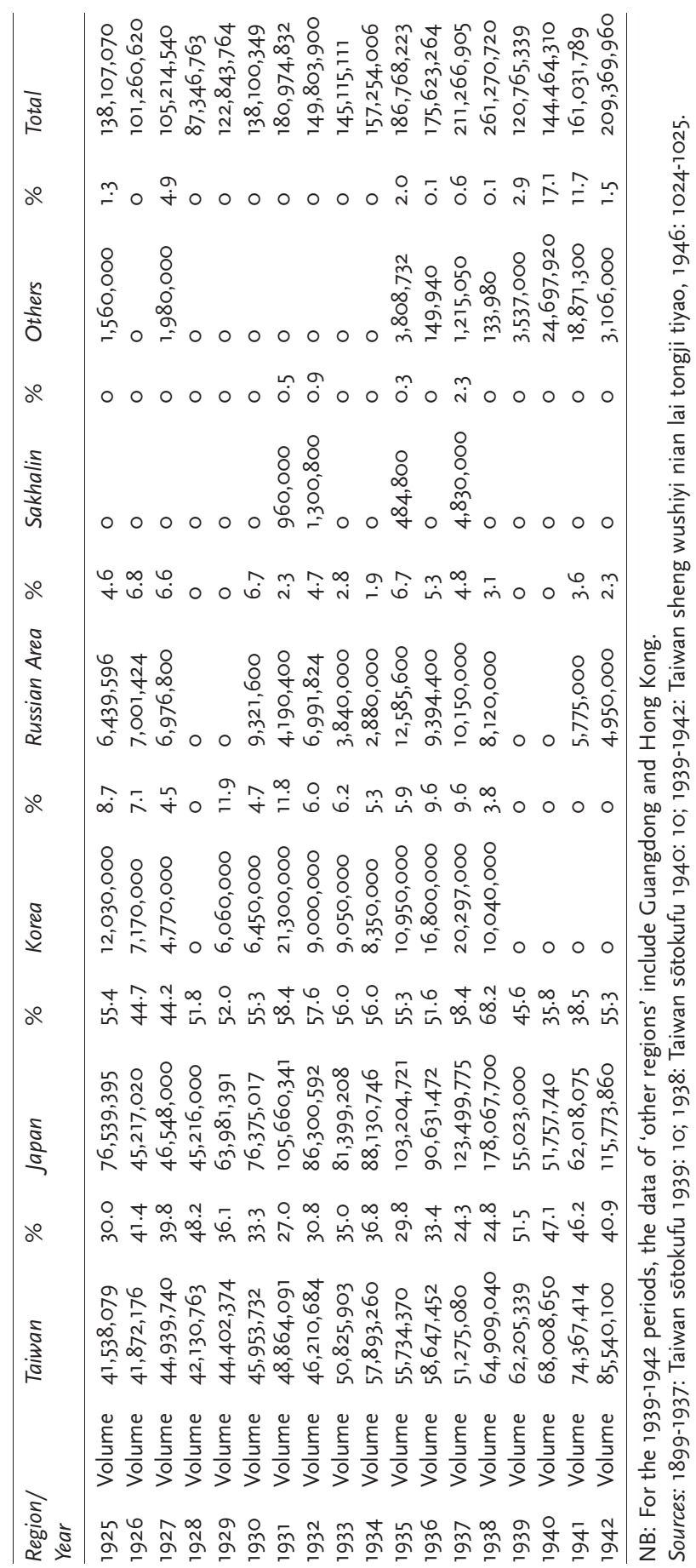


guaranteed by the Korean Government-General and became very stable (Tanaka 1997: 154). The share of Taiwanese salt on the Korean market was on average only 7 per cent of imported salt (Tanaka I997: I50-I52).

Exports of Taiwanese salt to Sakhalin began in 1909. A contract was signed with Sakhalin merchant Nishita Akari for marketing of Taiwanese salt there. On September I7, I9I4 the Taiwanese authorities decided to annul the contract, and the next day they signed a new agreement with the Taiwan Salt Industry Company giving it exclusive rights for export of salt to Sakhalin (Ishinaga I942: 231).

\section{Improvement of the quality of Taiwanese salt}

After the Japanese government gave permission to Kotama Gentarō to establish a Taiwanese salt monopoly, it became worried about the possibility of Taiwanese competition and its harmful influence on the Japanese domestic salt market. In June I905 the Japanese Table Salt Monopoly law came into force, limiting the amount of salt that could be imported to Japan in an attempt to protect domestic traders from the competition. ${ }^{8}$ Supply of table salt for Japanese living in Taiwan was the responsibility of the Taiwanese Government-General. Because Taiwanese table salt formerly contained sizable quantities of mud and soil, it had a bright yellow and black color. The Taiwanese people were used to colored table salt, but the Japanese expected salt to be pure white. The Taiwanese colonial authorities were thus obliged to temporarily organize the import of Japanese salt for the needs of their own citizens. In the meantime they made efforts to improve the quality of Taiwanese salt to substitute for these imports (Takegoe I985: 276-277).

Improvements in production techniques improved the quality of Taiwanese salt so that Japanese consumers in Taiwan and in Japan accepted it. In the I930s, the Japanese Monopoly Bureau set up salt quality standards that caused difficulties for imports of Taiwanese salt to Japan. In response, the head of the Taiwanese Salt and Camphor Division urged salt producers to face new problems (Taiwan sōtokufu I985: I35-136). The quality gradually improved. It was able to compete with Liaodong and Qingdao salt and eventually surpassed them in quality (Hatanaka 1939: 279). This result laid a strong foundation for further development of the industry.

Transport techniques and packaging were also improved to diminish the marketing costs and to match the rise in the quality of the product. Refined as well as natural salt had previously been packed into cheap hemp bags. Rising standards of living made it necessary to improve salt packing standards to meet sanitary standards and customers' ex- 
pectations. Local authorities in Taiwan demanded that salt traders use paper bags (Taiwan sōtokufu shenbaisenbaikyoku a: II4).

Export of Taiwanese salt to Japan was linked to the development of the Japanese soda industry. Japan utilized salt mostly to produce sodium carbonate and soy sauce. Before World War One, salt used for industrial purposes constituted only 4.5 per cent of the demand on the salt market. After the outbreak of the war, Japan experienced a period of fast industrial development. A new method of producing sodium carbonate was developed. This method relied on salt; therefore stable supplies of this raw material were needed. European and North American soda industries were usually established close to abundant resources of rock salt or saline water; thus they could secure a cheap supply of salt, and the cost of raw materials within overall production costs was very small. On the other hand, Japanese salt was traditionally used as table salt, and because of its high quality and price, it was not well suited to be used as a raw material in the industrial production of soda. This was the main reason Japanese factories had to depend on salt from colonies (Taiwan) or territories (Liaodong, Qingdao) controlled by Japan. After the Mukden Incident of I93I, the military industrial needs sharply increased the demand for caustic soda (Kozawa 2000: 199200). Stable supplies of salt became a very urgent matter for Japanese entrepreneurs.

The soda industry was closely linked to military industrial needs. For example, soda was obtained during electrolysis of salt and water. Among the by-products of the process were hydrogen and chlorine. In later years, hydrogen was used by chemical industries as a raw material in the production of synthetic fertilizers, synthetic petroleum, and the like (Hatanaka I939: 282). During the war, the Japanese paid close attention to the soda industry's development. The demands of the soda industry required an increase in the supply of industrial salt.

When Japan started preparing for war, a new policy determined that all supply sources should be located within the Japanese imperial zone. The Japanese government implemented 'Close First, Far Away Second' policies to guide the supply of salt for the empire. According to the distance of the salt-producing territory to Japan, the salt supply was divided into three categories: close overseas salt, less close overseas salt, far away overseas salt. Taiwan, Guandong, Manchuria and North China all belonged to the 'close overseas' category. The goal of the government was to increase salt supplies from 'close overseas' regions so that they constituted 80 per cent of overall salt supplies. In order to meet these demands, in 1937 Taiwan increased salt production to 50,000 tons, 5.5 times more than in 1932 (Taiwan sōtokufu shenbaisenbaikyoku I938: 3-5). 
Japanese industry then invested in the development of big salt-producing companies in Taiwan. Taiwan not only became the most important supplier of salt to Japan, but also developed its own soda industry.

\section{Conclusions}

The Taiwanese salt distribution network was developed under the monopoly system. The salt distribution network had to cover the whole island. Colonial authorities initially gave monopoly licenses to local power holders, and they utilized the monopoly and its dense distribution network to increase control over local society.

Those who profited the most from the monopoly were traders with wholesale licenses. The monopoly enabled them to increase their financial assets and to make close contacts with the officials. The wholesalers became new local elites and the first entrepreneurs in the nascent salt industry. Under the monopoly system the Japanese government expanded distribution networks of Taiwanese salt overseas and enabled Japanese zaibatsu to completely dominate the salt industry as well as chemical industries related to it. The salt distribution system linked Taiwan vertically to Japan in the division of work based on principles of center-colony relations. Significant investment of Japanese capital brought new technologies to Taiwan and laid the foundations for the industrial development of the relatively small island.

\section{Notes}

I See: Lu I954: 89-94; Lu I955: 22-28; Lu I956: 24-30; Lu I958: 56-64; Lu I972: I-I0; Zeng 1953; Zhang I955; Chen I991: 579-608.

2 Taiwan sōtokufu I92I: 2. According to the sixth paragraph of this law, it was to be in force for only three years, but the period was continuously extended, until finally this led to a movement for abolishment of 'law 63'.

3 Gu Xianrong denki hensankai I939: 51. When Gotō Shimpei was dealing with the uprising of Jian Dashi and Chen Qiuju, a local official told him, 'Formerly I accompanied official $\mathrm{Gu}$ Xianrong; he was dealing with affairs with great skill as he was responsible for relief efforts and design of all policies related to this field.' Gotō then sent an invitation to Gu's family residence in Lugang asking $\mathrm{Gu}$ to become his advisor.

4 Gu Xianrong denki hensankai 1939: 5I.

5 Gu Xianrong denki hensankai I939: 54-55. Gotō was in charge of the Monopoly Bureau from June I90I until November I902.

6 A number of Japanese and Taiwanese founded the TSPC with a capital investment of 2.5 million yen. The Company purchased old salt farms and developed new ones through government control of management, and worked to improve the quality of salt. The government wanted to turn the salt industry into an enterprise in which Ja- 
panese and Taiwanese were bound by a common interest to implement its colonial policy (Taiwan sōtokufu senbaikyoku i924b: 79-82).

7 Chen Fuqian (I834-I882) was a businessman involved in the export of sugar; he became the richest man in southern Taiwan.

8 Japan's Salt Monopoly Law was promulgated on December 3I, I904 and was in force from June I, I905 until April I997, when it was finally abolished (Kozawa Tokio 2000: I-6).

\section{References}

Chen Tsu-yu (I99I), 'Riju shiqi taiwan yanye de fazhan - taiwan jingji xiandaihua yu jishu yizhuan zhi ge an yanjiu' (The Development of the Taiwanese Salt Industry during the Japanese Occupation - A Case Study of the Modernization of Taiwanese Economy and Technology Transfer), in Zhongyang yanjiuyuan jindaishi yanjiusuo edit, Zhongguo xiandaihua lunwenji (Collection of Essays on Chinese Modernization): 579-609. Taipei: Zhongyang yanjiuyuan jindaishi yanjiusuo.

—(I993), 'The Salt Industry in Taiwan, I895-I945'. Journal of Salt-History, I: 39-62.

Fujuzaki Seinosuke (1985), Taiwan zenshi (Taiwan Gazetteer), vol. I. Taipei: Chengwen chubanshe (reprint of the I930 edition).

$\mathrm{Gu}$ Xianrong denki hensankai (The editorial committee of the biography of Gu Xianrong) (1939), Gu Xianrong zhuan (The Biography of Gu Xianrong). Taipei: Gu Xianrong denki hensankai.

Gu Yue (I957a), 'Riju shiqi beitai lieshenchuan' (Collected Biographies of North Taiwanese Gentry during Japanese Rule), vol. II, Taipei wenwu (Taipei Cultural Relics) 5: 2-3. Taipei: Taipei shi wenxian weiyuanhui.

- (I957b), 'Riju shiqi beitai lieshenchuan' (Collected Biographies of North Taiwanese Gentry during Japanese Rule), vol. III, Taipei wenwu 5: 4. Taipei: Taipei shi wenxian weiyuanhui.

Hatanaka Yasuji (1939), Taiwan shenbaisenbai jigyō nenkan (Yearbook of Taiwan Monopoly Affairs). Taipei: Taiwan to kaigaisha.

Ishinaga Hisakuma (I942), Budai shokuyen shenbaisenbaishi (History of Budai's Table Salt Gazetteer). Taipei: Taiwan sōtokufu shenbaisenbaikyoku.

Ishisaka Sōsaku (1985), Taitō tasatsu jiki (True Records from Investigation of Taiwan Island). Taipei: Chengwen chubanshe (reprint of the I904 edition).

Kōnan sinbunsha (ed.) (I947), Taiwan jinsikan (Biographies of Taiwanese Personages). Taipei: Kōnan sinbunsha.

Kozawa Tokio (2000), Kindai Nihon yengyōshi (The History of the Modern Japanese Salt Industry). Tokyo: Daimedo.

Lin Jin-fa (I933), Taiwan kansin nenkan (A Yearbook of Taiwan Officials and Gentry). Taipei: Minshukoronsha.

Linji Taiwan kyukan chōsakai (Provisional Investigative Committee of Taiwan Old Customs) (ed.) (1985), Taiwan keisei kaiyō (An Outline of Taiwan's Situation), vol. I. Taipei: Chengwen chubanshe (reprint of 1902 edition).

Liu, Ts'ui-jung (1989), 'Features of Imperfect Competition on the Ming-Ching Salt Market', in Liu, Ts'ui-jung (ed.) The Second Conference on Modern Chinese Economic History: 559627. Taipei: Institute of Economics, Academia Sinica.

Lu Jiaxing (I954), 'Tainan xian yanchang shihua' (Historical Changes of Tainan County's Salt Market), Nanying wenxian (South Seas Historica) 2 (I.2): 89-94, Tainan: Tainan xian zhengfu.

-(I955), 'Tainan shi yanchang yange zhiyao' (A Summary of the Evolution of Tainan City's Salt Market). Tainan wenhua (Tainan Culture) 4(3): 22-28. Tainan: Tainan shi wenxian weiyuanhui. 
-(1956), 'Taiwan qingji yan zhi yu yan zhuanmai' (Organization of Salt Trade and Salt Monopoly on Taiwan during the Qing Dynasty). Tainan wenhua (Tainan Culture) 5:I: 2430. Tainan: Tainan shi wenxian weiyuanhui.

-(I958), 'Qingji taiwan beibu zhi yanwu' (Salt Affairs in Northern Taiwan during the Qing dynasty). Taipei wenwu (Taipei Cultural Relics) 7(3): 56-64. Taipei: Taipei shi wenxian weiyuanhui.

-(I972), 'Jieshao Tainan xian Qianlong shiqi jiu yan chengtu' (Description of the Map of Old Salt Monopoly in Tainan County During the Qianlong Reign). Nanying wenxian (South Seas Historica) I7: I-IO. Tainan xian: Tainan xian zhengfu minzheng ju.

Miyazaki Kenzo (I93I), Chin Chuwa den (Biography of Chen Zhonghe). Taipei: Taiwan Daily News.

Okata Takekura (ed.) (I94I), Taiwan nenkan (Taiwan Yearbook). Taipei: Chengwen chubanshe.

Sima Xiaoqing (1987), Taiwan wu da jiazu (Taiwan's Five Big Families), vol. I. Taipei: Zili wanbao (The Independence Evening Post).

Taiwan senbaisenbaikyoku (Monopoly Bureau of Taiwan Government-General) (ed.) (I924), Taiwan senbai hoki (Regulations of Taiwan Monopoly). Taipei: Taiwan shenbaisenbaikyoku.

-(Monopoly Bureau of Taiwan Government-General) (ed.) (I94I), Taiwan shu senbai shi (History of Alcohol Monopoly in Taiwan). Taipei: Taiwan senbaisenbaikyoku.

Taiwan sinminpōsha (1937), Taiwan jinsikan (Biographies of Taiwanese Personages). Taipei: Taiwan sinminpōsha.

Taiwan sōtokufu (The Taiwan Government-General) (August I7, I899), Fuhō (Official Gazette) no. 584. Taipei: Taiwan sōtokufu.

-(I921), Taiwan ni shikō subeki hōlin ni kansuru hōritsu (The Regulations of Taiwan). Taipei: Taiwan sōtokufu.

—(July I926), Fuhō (Official Gazette) no. 3846. Taipei: Taiwan sōtokufu.

-(I939), Shenbai Senbai jigyō daiz7 nenbo (Monopoly Affairs, Yearly Report no. 37), Table Salt Volume. Taipei: Taiwan sōtokufu shenbaisenbaikyoku.

—(I940), Shenbai Senbai jijyō daiz8 nenbo (Monopoly Affairs, Yearly Report no. 38), Table Salt Volume. Taipei: Taiwan sōtokufu shenbaisenbaikyoku.

-(I985a), Shisheyonjunen no Taiwan (Taiwan after Ruling 40 Years). Taipei: Chengwen chubanshe (reprint of the I935 edition).

-(I985b), Taiwan tōchi kaiyō (Outline of Taiwan Administration), vol. 2. Taipei: Chengwen chubanshe (reprint of the 1945 edition).

Taiwan sōtokufu kanbobushoka ed. (I985), Taiwan tochi soran (A General Survey of Taiwan Administration), vol. 2. Taipei: Chengwen chubanshe (reprint of 1908 edition).

Taiwan sōtokufu linjijōhōbu (Provisional Information Division of Taiwan Government-General) (March I938), Buhō (Division Report), no. I8.

Taiwan sōtokufu shenbaisenbaikyoku (Monopoly Bureau of Taiwan Government-General) (ed.) (1924a), Taiwan senbai hoki (Regulations of Taiwan Monopoly). Taipei: Taiwan sōtokufu senbaisenbaikyoku.

—(I924b), Taiwanyen shenbaisenbaishi (The Gazetteer of the Salt Monopoly in Taiwan). Taipei: Taiwan sōtokufu.

—(I936), Taiwan no shenbai jigyō (Monopoly Enterprises in Taiwan). Taipei: Taiwan sōtokufu.

—(a), Nettai sangyō chōsasho (Investigation of Tropical Industries), Second Volume. Place and year of publication not provided.

-(March 1938), 'Taiwan kōgyōyenden no kakuchō’ (Expansion of Taiwanese Industrial Salt Fields), in Buhō (Division Report), I8: 3-Io.

Taiwan sōtokufu shenbaisenbaikyoku shomuka (Taiwan Government-General General Affairs Department) (ed.) (I9II), Taiwan sōtokufu shenbaisenbaikyoku hoki shupō (A Collection 
of Regulations of the Monopoly Bureau of Taiwan Government-General). Taipai: Taiwan sōtokufu senbaisenbaikyoku.

Takegoe Yosaburō (I985), Taiwan tochi shi (Taiwan Administrative Gazetteer), vol. 2. Taipei: Chengwen chubanshe (reprint of the i905 edition).

Tanaka Ichiji (1985), Taiwan jijō no shenden (Promotion of Taiwanese Affairs). Taipei: Chengwen chubanshe (reprint of the I9I9 edition).

Tanaka Masataka (I996), 'Tōkanhu no Yengyō seisaku ni tsuite' (A study on Korean tokanhu's salt policy). Hitotsubashi Ronsō一橋論叢, II5:2: I36-I5I.

- (I997), 'Shokuminchiki no yenjukyū to minkan yengyō' (The supply and demand of salt and private salt industry during Japanese colonial period). Chōsenshi kenkyūkai ronbunshu 35: I45-I73.

Tsurumi Yūske (I943), Gotō Shimpei den (The Biography of Gotō Shimpei). Tokyo: The Association of Pacific Ocean Press.

Yanohara Tadao, Zhou Xianwen, tr. (I985), Riben diguo zhuyi xia zhi taiwan (Taiwan under Japanese Imperialism). Taipei: Pamier shudian.

Yao Yuzhang (I977), Taiwan maoyi shi (History of Taiwan Trade). Taipei: Sanmin shuju.

Zeng Wangyang (I953), Taiwan zhi yan (Taiwanese Salt). Taipei: Taiwan yinhang jingji yanjiushi.

Zhang Xiuwen (I955), Taiwan yanye shi (History of the Taiwanese Salt Industry). Taipei: Taiwan yinhang jingji yanjiushi.

Zhao Shi (I985), Gaoxiong renwu pingshu (Comments on Prominent Persons from Gaoxiong), vol. 2. Gaoxiong: Chunhui chubanshe. 



\title{
6 Semi-Colonialism and Cultural Interaction: Chinese Indentured Labor in World War One France and the Sino-French Connection
}

\author{
Paul J. Bailey
}

\section{Introduction}

During World War One, beginning in I9ı6, nearly I40,000 Chinese laborers (mainly from the northern province of Shandong) were recruited by the British and French governments to make up for labor shortages in France, as well as to release British dockworkers in France for military duty. Although the French government looked principally to its formal colonies and protectorates for labor manpower during the war (recruiting 78,566 Algerians; 48,955 Vietnamese; and 35,506 Moroccans, for example), it imported nearly 37,000 Chinese workers. Those recruited by Britain constituted a larger proportion of its overseas labor force used in France; organized into I95 'labor battalions' and designated the Chinese Labor Corps, Chinese workers totalled 96,000 (compared to 48,000 Indians and 21,000 South African blacks) (Cross I980: 615-616; I983: 35-36; Summerskill I982: 163; Horne 1985: 59). During their sojourn in France, these Chinese workers were involved in a wide variety of war-related work such as unloading goods and raw materials (e.g. coal) in the coastal docks, transportation, armaments and munitions production, machinery and equipment maintenance, road and aerodrome construction and even burial of the war dead.

In addition to sanctioning the British and French recruitment of Chinese labor in I9I6-I9I8, the Chinese government in Beijing itself formally declared war on Germany in August I9I7 (the only concrete consequence of which was the sequestration of German property and shipping in China). Together, these two acts earned China the right to attend the Versailles Peace Conference at the end of the war. China's participation in the conference, in effect, symbolized for the first time during the modern era the western powers' acquiescence in China's membership of the international community following a century of re- 
peated humiliations at the hands of western powers (and latterly Japan) determined to enhance their economic, commercial and territorial privileges in the country. In many ways by the early twentieth century China had become - in the later words of Mao Zedong - a 'semi-colony', the 'victim' of an informal imperialism by means of which the privileges held by foreigners and their governments in China impinged upon the country's sovereignty and limited its freedom of action. Such a 'colonial' status was ironically demonstrated during the French recruitment of Chinese labor in I9I6-I9I7; Chinese workers were categorised together with workers from the French colonies and placed under the administrative supervision of the Service d'organisation des travailleurs coloniaux (Colonial Labor Service).

Chinese hopes in I9I9 for a new era of international relations in which China would be treated as an equal ultimately foundered on the rocks of realpolitik, as the Versailles Peace Treaty neither compelled Japan to return to China the leasehold territory of Jiaozhou (Shandong province) that it had seized from Germany in I9I4, nor amended in any substantial way the 'unequal treaty system' in China. China's only gains from its contribution to the allied cause in World War One were the postponement of Boxer Indemnity payments for five years, and a slight increase allowed in import tariff levels. Decisions taken by the big powers at Versailles thus seemed to confirm China's status as the helpless (and hapless) victim of western and Japanese imperialism (further demonstrated by the fact that the anti-Chinese legislation so prevalent in the US, Canada, Australia and New Zealand before World War One continued unabated after I9I8). Not surprisingly, the story of Chinese indentured labor in World War One France has slipped into a historical black hole - in the West because of the conventionally Eurocentric approach often adopted by western historians of World War One, and in China because it represents simply another shameful and humiliating episode in the western exploitation of China during the nineteenth and first half of the twentieth centuries and therefore does not merit any in-depth study.

This chapter will argue that the history of Chinese indentured labor in World War One France should be placed within significantly larger contexts. Not only was it an important episode in the longer history of Chinese worker migration that began in the mid-nineteenth century with the illegal 'coolie trade' carried out in China's treaty ports, but it also illuminates in very interesting ways Sino-French mutual perceptions and cultural interaction during the first two decades of the twentieth century. Such interaction, and the fact that Chinese politicians and intellectuals were active participants in the recruitment (and that they invested the project with their own political, social and cultural agenda) impels us to view China as a more autonomous actor on the world 
stage at this time than has hitherto been assumed in the general histories of modern China. Finally, the chapter suggests that the specifically political use made by the Chinese government in I9I6-I9I8 of Chinese overseas workers intriguingly anticipates the attitude and practices of the new Chinese Communist regime after 1949, especially in its relations with Africa.

\section{Chinese support for the recruitment}

Active Chinese support and participation clearly distinguishes the French recruitment of Chinese workers during World War One from the unregulated and illegal 'coolie trade' of the nineteenth century, when up to 500,000 Chinese were recruited principally to work on sugar plantations in South America and the Caribbean (intriguingly, a note from the French Foreign Ministry in ${ }^{8} 86_{3}$ suggested recruiting Chinese men and their families from central Chinese provinces to cultivate cotton and cereals in France's African colonies). ${ }^{\mathrm{I}}$ Both the French and British recruitment of Chinese workers in I9I6-I9I7 were based on regulations first drawn up by the Qing government in I866 (and originally rejected by the British and French governments) that imposed a time limit on the indenture, insisted on transparency of contracts (texts to be openly published in the Chinese press and to specify clearly duration, wage rates and number of working hours), guaranteed free medical assistance and free passage home after the expiry of the contract, and provided for the stationing of Chinese official inspectors both at the embarkation ports in China and in France to oversee the Chinese workers' welfare.

Two main Chinese constituencies were involved in the support for the recruitment of Chinese labor in World War One France. The first included government and official elites, who responded enthusiastically to the French request for Chinese labor in late I9I5 in order to enhance China's standing at a future peace conference. In fact, President Yuan Shikai - in order to forestall the Japanese takeover of Germany's concession area in Shandong province (Japan had declared war on Germany in I9I4 as Britain's ally) - had proposed (without success) China's military participation in the war on the side of the entente powers as soon as war had begun (Chi I970: 20,72; Lo 1976: 2.559-561). On two further occasions, in I9I5 and I9I7, the Chinese government proposed sending troops to the Dardanelles and the Western Front respectively (La Fargue I937: 83-84; Chi I970: I29-I30). Significantly, while the British and American governments were not especially keen on the proposals (mainly for logistical and financial reasons, but also because of a lack of confidence in the potential usefulness of Chinese military 
participation) both the French government and military were. Joint proposals drawn up by the French and Chinese governments in the spring of I9I8 (before the definitive shelving of any such plan for Chinese military participation in March) would have provided for the financing of a Chinese expeditionary force comprising 43 battalions (I,543 officers and 44,900 troops) and additional special units such as "police contingents', 'sanitation brigades' and 'communications teams'. '

A second, and perhaps more intriguing, Chinese constituency in favor of the recruitment was a group of Francophile intellectuals and educators who cultivated extensive links with both Chinese political figures and French official and intellectual circles. Since the early years of the twentieth century, in fact, this Chinese Francophile 'lobby' had been energetically promoting Sino-French cultural relations and the importance of Chinese overseas study in France. The most prominent member of this group was Li Shizeng (I88I-I973), son of a Qing court official and who himself had gone to France in 1902 as an 'embassy student'. While there he enrolled in the Ecole Pratique d'Agriculture in Montargis (just outside Paris) and later, in I905, studied chemistry and biology at the Institut Pasteur in Paris. Other members of this Francophile lobby included anti-Qing revolutionaries and future prominent figures of the Guomindang (Nationalist Party) in the I920s - Cai Yuanpei (I868-1940), Wu Zhihui (I864-I953) and Zhang Jingjiang (I877I950) - all of whom were in France at the same time as Li. Li Shizeng became a fervent admirer of French culture (which included French anarchism) and often contrasted the 'worthy' ideals of the French secular republic, which he described as representing 'freedom', 'creativity' and 'pacifism', with the apparently more 'brutal' German ideals of 'autocracy, utilitarianism and militarism'. While in Paris Li built up a wide network of contacts with French politicians and intellectuals, as well as helping to publish a Chinese-language anarchist journal, Xin shiji (New Century). Li also opened a night school for the Chinese workers he had recruited after 1908 for employment in the beancurd factory he had established in Garenne-Colombes outside Paris. For Li, France was a republic par excellence, free of what he perceived as the 'baneful' influences of monarchy and religion - and thus an ideal environment in which to work and study. In I9I2, on his return to China, he founded the Association for Frugal Study in France (liufa jianxuehui), which helped send nearly too Chinese students to France before the outbreak of World War One. In the same year Cai Yuanpei, who had become the first minister of education in the new Chinese Republic, asserted that the French revolutionary ideals of freedom, equality and universal brotherhood were comparable to such Confucian values of ren (sense of compassion, humaneness) (Cai n.d.). 


\section{The Sino-French connection and mutual perceptions}

The French intellectuals and politicians with whom Li came into contact were equally admiring of China; their inclination to link the traditions of French and Chinese cultures represented, in effect, a unique aspect of general western attitudes towards China in the late nineteenth and early twentieth centuries. Of course, in many ways French diplomats and officials at home and in China shared the same assumptions of western superiority and the imperative of the western 'civilizing mission' as their British, American or German counterparts. However, what set French attitudes apart was the assumption that France was the one European country that could act as an effective mediator between China and the West. This was not only because France perceived itself as more sensitive to, and appreciative of, Chinese culture but also because it was assumed in many ways that French and Chinese cultures had much in common. Subscribers to these views included socialist politicians such as Marius Moutet and Edouard Heriot, scholarpoliticians such as Paul Painlevé and prominent academics such as the historian Alphonse Aulard. ${ }^{3}$

What gave urgency to the French insistence that France's role in China was uniquely different from that of other western powers was an increasing fear that China was inexorably falling under the sway of Anglo-Saxon cultural influence, a consequence of Britain's predominant economic presence in China. In their effort to counter such an influence, French officials, politicians, intellectuals and scholars sought to emphasize a complementarity between French and Chinese cultures. Thus in its respect for learning, secularism, joie de vivre and aversion to war, French culture was seen to complement the humanist values of Confucius. Even the central role of the family in Chinese society found an echo in the Frenchman's respect for family life. As the president of the Franco-Chinese Friendship Association (Association amicale francochinoise), ${ }^{4}$ Georges Dubail (a former minister to China) noted in I907:

The Chinese and French are profound and wise philosophers; they are equally good family men (bons pères de famille), prudent businessmen and faithful associates. ${ }^{5}$

The idea that the French and Chinese characters were alike in their proclivity for hard work, down-to-earth wisdom and practice of family virtues was reiterated in I9II by another president of the Association, Georges Ducrocq:

Of all the foreigners who are in China, there are few more capable of adapting to China's way of life than the Frenchman. Like 
us, the Chinese take a delight in family life; like us, they have an appetite for work and a moralistic turn of mind, a practical wisdom for daily life... that you will find in Confucius as in La Fontaine. ${ }^{6}$

For Ducrocq, only France could play the intermediary role between the West and China precisely because of the cultural affinity the two countries shared. It would be hard to imagine a British diplomat or scholar (or an American, for that matter) of the time describing Sino-British relations (or Sino-American relations) in quite the same way.

Li Shizeng and others of the Francophile 'lobby' not surprisingly welcomed the prospect of France's recruitment of Chinese labor in I9I6 as part of their larger cultural and social agenda. Li confidently predicted that enormous benefits would accrue to China, as Chinese laborers in France would form the vanguard of an educated workforce contributing to the diffusion of industrial skills and reform of society on their return. ${ }^{7}$ While in France, Li claimed, Chinese workers would become truly 'civilized', divesting themselves of their 'backward' and 'unseemly' habits and customs. At the opening meeting of the SinoFrench Education Association (Huafa jiaoyuhui) that Li had helped create in I9I6 with the help of prominent French intellectuals such as Alphonse Aulard to promote the expansion of Sino-French cultural relations, the affinities between Chinese and French cultures were again highlighted. Aulard himself, echoing Cai Yuanpei's earlier observation, declared that the humanist philosophy of Confucius anticipated the ideals of the French Revolution. ${ }^{8}$ Two years later, a French military official in China on a government mission to explore ways of enhancing French cultural influence in the country, confidently proclaimed:

The Chinese is a philosopher, poet and artist, and it is for this reason one says that he is the Frenchman of the Far East. ${ }^{9}$

\section{The Chinese worker experience in World War One France}

Significantly, however, actual French attitudes towards the indentured Chinese workers during World War One, especially among officials and employers, undermined (and belied) the grandiose Gallic rhetoric of Sino-French cultural affinity. Mention has already been made of the fact that Chinese workers were rather unceremoniously lumped together with workers from France's colonies and placed under the administrative control of the Colonial Labor Service. In the eyes of French official authorities (as well as their British counterparts), Chinese workers were often perceived and described in condescending terms as 
either 'childlike' or 'malleable'. More intriguingly, there was always an underlying fear of a 'loss of face' on the part of French authorities visà-vis the Chinese workers, a concern that revealed more about French feelings of insecurity than anything else. Instructions from the Colonial Labor Service to potential French employers of Chinese workers in September I9I6 perfectly illustrated this French obsession with 'face': ${ }^{\circ}$

The Chinese have considerable self-pride (amour-propre), and it is therefore appropriate to treat them with kindness, and give them a reward, however, minimal, every time they try to do something well. An act of brutality will bring the opposite of what is intended, since anyone giving in to anger will lose all credibility in their eyes... It is imperative that employers, foremen, etc., realize that in the view of the Chinese, to give in to an external manifestation of anger is proof of an inability to control oneself and thus (in the eyes of the Chinese) to remain a barbarian. ${ }^{\text {II }}$

Furthermore, because indentured Chinese workers did not, in fact, behave in ways expected of them (i.e., to be 'docile', 'passive', 'hardworking'), by I9I8 French employers had become increasingly hostile to the idea of employing them. Chinese workers often protested against breaches of their contracts, the dangerous nature of their work, and the harsh treatment they at times received. In some cases Chinese workers, such as those at a munitions plant in St. Louis de Rhône (near Arles) simply walked off the job when refused overtime pay and headed for the port of Marseille. At dockyards such as Saint-Nazaire French employers continually criticized Chinese workers as 'lazy troublemakers' who refused to unload coal because they considered such a task unsafe (and not part of their contract). In some cases, disputes between Chinese workers and French soldiers (as happened in Rouen in March I9I8) could lead to violence. ${ }^{\text {I2 }}$ Dissatisfaction with the 'unruly' Chinese workers had reached such a fever pitch by I9I8 that the Ministry of War was referring to them as 'undesirables'. At the end of the war meetings held by representatives of the Ministry of War, Ministry of Justice and local army commands actually discussed complaints sent in from local communities (especially from the Somme region and the Pas de Calais) about the Chinese workers in their midst. Such complaints referred to crimes 'of all sorts' and suggested that in certain villages local people no longer 'felt safe' and were contemplating quitting their village unless the Chinese workers were withdrawn. ${ }^{\mathrm{I3}}$ 


\section{Conclusion}

The story of Chinese indentured labor in World War One France ended in disappointment and recrimination. As mentioned, the Versailles Peace Treaty ultimately confirmed China's status as a minor player on the world stage and continued acceptance of sovereignty-undermining foreign privilege in the country itself. Furthermore, the ambitious plans of the Chinese Francophile lobby (of which Chinese indentured labor in France would have constituted an element) to strengthen and expand Sino-French cultural relations never came to fruition. The hostility towards Chinese workers by French employers and local communities exposed the hypocrisy of French rhetoric concerning a 'special relationship' between China and France (there is an interesting parallel here with the sorry plight of Chinese immigrants in the United States set against the context of an American discourse that highlighted a 'special relationship' between the US and China based on the former's genuine desire to 'help' and 'assist' the latter) (Hunt I983).

Yet three little-known events in the wake of World War One indicate that though China may indeed have been a 'semi-colony' during the first decades of the twentieth century, Sino-French interaction at this time (what I call the 'Sino-French connection') could proceed in two directions. In September 1919, while Chinese Foreign Minister Lu Chengxiang (I87I-I949) was in France attending the Versailles Peace Conference, he met French President Raymond Poincaré; as a gesture of support for an impoverished France and to demonstrate China's civilized commitment to education, Lu donated 50,000 francs on behalf of the Chinese government to help restore educational facilities in war-shattered Verdun. ${ }^{\text {I4 }}$ This was not the only assistance China provided France; two years later, at the height of the postwar economic depression in France, the Chinese government sent food relief in the shape of 400 tons of eggs. ${ }^{15}$ In 1920, when Paul Painlevé visited China to confer on President Xu Shichang an honorary D.Litt. degree from the University of Paris, he was in turn offered I00,000 francs as a Chinese contribution to the newly created Institut des Hautes Etudes Chinoises in Paris (and thereby hoping to enhance interest in Chinese culture in France). Finally, post-I949 Chinese historiography may have consigned the story of Chinese indentured labor in World War One France to the dustbin because it was seen to represent simply another example of China's exploitation by the western powers, but in one fascinating respect the approach adopted by the Chinese Republican government during World War One in its support for the sending of Chinese workers to France has parallels with the foreign policy of the post-I949 Maoist state. Chinese government officials in their discussions with French and British authorities in I9I6 made a point of describing Chi- 
na's planned labor contribution to the war as an important symbol of the country's commitment to world peace - hence earning it the right to be treated as an equal on the international stage once the war ended. $^{\text {I6 }}$ This specifically political use of Chinese labor overseas that the Chinese government made at this time anticipated post-I949 China's use of overseas labor. Thus when the People's Republic signed an agreement with Tanzania in the late ig6os to help finance and build the Tanzam Railroad with the aid of I5,000 Chinese technicians and workers it was deliberately using this dramatic gesture of international aid as a symbol of China's political commitment to the non-aligned world (and to Afro-Asian solidarity in particular). Such a parallel alone indicates that the virtually forgotten story of Chinese indentured labor in World War One France deserves to be revisited with a fresh perspective.

\section{Notes}

I Note from Foreign Ministry to Ministry of Marine and Colonies (I863). Fonds ministériels/généralités: Carton I30, Dossier II25. Centre d'archives d'outre-mer (Aix-en-Provence, France).

2 Fonds Clemenceau, 6N I30: Rapports des attachés militaires. Archives de la service historique de l'armée de terre (Chateau de Vincennes, Paris).

3 I have argued elsewhere that this modern French approach towards China drew on a long tradition of cultural and intellectual relativism that dated from the sixteenth century. See P. Bailey, 'Voltaire and Confucius: French Attitudes Towards China in the Early Twentieth Century', History of European Ideas I4.6 (November I992): 8I9-82I.

4 Founded in 1907 , the Association was one of a number of scholarly or semi-official organizations established at this time to promote Franco-Chinese cultural relations.

5 Bulletin de l'association amicale franco-chinoise I.I (July I9I7): I7-I8.

6 Bulletin de l'association amicale franco-chinoise 3.3 (July I9II).

7 Lü'Ou jiaoyu yundong (The Educational Movement in Europe) (Tours: n.p., I9I6): 8283. For another article Li wrote on the same theme in I9I7, see Li Shizeng xiansheng wenji (Collected Writings of Li Shizeng) (Taibei: Zhongyang weiyuanhui dangshi weiyuanhui, 1980), I: 220-225.

8 The text of Aulard's speech (translated into Chinese) is in Fufa qingong jianxue yundong shiliao (Historical Materials on the Diligent Work and Frugal Study Movement in France) (Beijing: Beijing chubanshe, I979-I98I), I: 202-203.

9 Archives du ministère des affaires etrangères (Paris), E-28-1/6.

Io Since western observations of the Chinese character often focused (and still do) on the significant role of 'face' in Chinese personal interactions, this French obsession with 'face' ironically provides another example of 'cultural affinity' between the two countries (although not an example that contemporary French observers would necessarily have thought of).

II Fonds Clemenceau, 6N I49: Mission de recrutement des ouvriers chinois. Archives du service historique de l'armée de terre.

I2 Archives nationales (Paris): Fi4 II3I: Main-d'oeuvre exotique.

I3 7N 2289: Affaires britanniques/travailleurs chinois. Archives du service historique de l'armée de terre. 
I4 La politique de Pékin (7 September, I9I9).

I5 La politique de Pékin (II June, I922).

I6 The last few lines of a song dedicated to the Chinese workers in France and written by a member of the Chinese official delegation at Versailles in I9I9 also underlined this point:

We, the children of sacred China, whose fate lies in heaven,

esteem the farmer and favor the artisan, but never resort to force.

Marching, marching ever marching.

All within the four seas are brothers.

We are an army of workers devoting ourselves to labor

in order to build peace for you, humanity.

La politique de Pékin (February 22, I920).

\section{References}

Archives du service historique de l'armée de terre (Paris): 6N I30, 6N I49, 7N 2289.

Archives du ministère des affaires etrangères (Paris): E-28-I/6.

Archives nationales (Paris): $\mathrm{F}^{\mathrm{I} 4}$ II3I.

Bailey, Paul (1992), 'Voltaire and Confucius: French Attitudes Towards China in the Early Twentieth Century'. History of European Ideas I4 (6): 8I7-837.

Bulletin de l'association amicale franco-chinoise (I9II-I9I7).

Cai, Yuanpei (n.d.), Cai Yuanpei wenji (The Collected Works of Cai Yuanpei). Hong Kong: Wenxue yanjiushe.

Centre d'archives d'outre-mer (Aix-en-Provence): Fonds ministériels/généralités.

Chi, Madelaine (1970), China Diplomacy 1914-1918. Cambridge, Mass: East Asia Research Centre, Harvard University.

Cross, Gary (1980), 'Toward Social Peace and Prosperity: The Politics of Immigration in France During the Era of the First World War'. French Historical Studies II (4): 610-632.

-(1983), Immigrant Workers in Industrial France. Philadelphia: Temple University Press.

Fufa qingong jianxue yundong shiliao (I979-198I). Beijing: Beijing chubanshe, I: 202-203.

Horne, John (1985), 'Immigrant Workers in France During World War One'. French Historical Studies I4 (I): $57-88$.

Hunt, Michael (1983). The Making of a Special Relationship: The United States and China to 1914. New York: Columbia University Press.

La Fargue, Thomas (1937), China and the World War. Stanford: Stanford University Press.

La politique de Pékin. Beijing (I919-I922).

Li, Shizeng (1980), Li Shizeng xiansheng wenji (Collected Writings of Li Shizeng). Taibei: Zhongyang weiyuanhui dangshi weiyuanhui.

Lo, Hui-min (ed.) (1976), The Correspondence of G.E. Morrison. Cambridge: Cambridge University Press.

Lü’Ou jiaoyu yundong (I9I6). Tours: Lü’ou zazhi she.

Summerskill, Michael (1982), China at the Western Front. London: Michael Summerskill. 


\title{
7 China's Rise: Some Considerations
}

\author{
Dora Martins
}

\section{Introduction}

In the last years, the emergence of China as an economic, political and cultural power has been a hot topic of discussion among scholars of Chinese studies. The main driving force of China's current re-emergence is the policy of 'reform and open up' (gaige kaifang 改革开放) initiated by Deng Xiaoping in 1978 , which stimulated specially its economy. While some scholars and also some foreign governments argue that this emergence represents a threat, others maintain that China is non-threatening. To respond to the perception that an emergent China is a threatening China, the Chinese government promoted the slogans of peaceful rise (heping jueqi 和平崛起) and peaceful development (heping fazhan 和平发展). These concepts followed another one adopted with the same spirit in the mid-I990s: the new security concept (xin anquan guan 新安全观), a new pattern which China would follow in the security relations with other countries. As defined by the Chinese government the four main features were: mutual trust (huxin 互 信), mutual benefit (huli 互利), equality (pingdeng 平等), and cooperation (hezuo 合作) later substituted by coordination (xiezuo 协作). This concept was mainly used as a slogan to show neighbouring countries that China was a peaceful and cooperative country. Both the new security concept and China's peaceful rise have been used by the Chinese government to show that China's development does not represent a threat to the region and to the world. These concepts were first used to try to convince China's neighboring countries of its cooperative intentions but later they were promoted by China all over the world. However, it is unclear whether China will always be peaceful in relating to other countries. There are strong believes that whenever its interests are threatened, China will use force. 
In this article, I will first identify the main features of China's current emergence and the meaning of the slogan 'peaceful rise'. Then I will argue that this is not a new phenomen in Chinese history and I will explain that the roots of the 'peaceful rise' concept can be found in Chinese ancient philosophies such as Confucianism and Daoism. I will conclude my article enquiring whether China will always adopt a peaceful behaviour when in relation to other countries, and analysing the main features of Chinese foreign policy.

\section{China's rise}

In the last decade, there has been a widespread debate among academics and politicians on China's rise and what impact it will have. This discussion has generated a great number of articles and books in China and around the world. ${ }^{\mathrm{I}}$

From the economic point of view, since the policy of 'reform and open up', China has indeed engaged in very rapid growth as one can see in chart 7.I. In recent years, the Chinese economy has been growing at an average high growth rate of approximately ro per cent. According to the International Monetary Fund, in 2007, China's Gross Domestic Product was estimated to have reached 9,928 billion yuan ( $€ \mathrm{I}, 094$ billion) and in 2013 it is expected to reach the 17,395 billion yuan (€ I,9I8 billion) mark.

\section{Chart 7.1 China's GDP evolution (billion yuan)*}

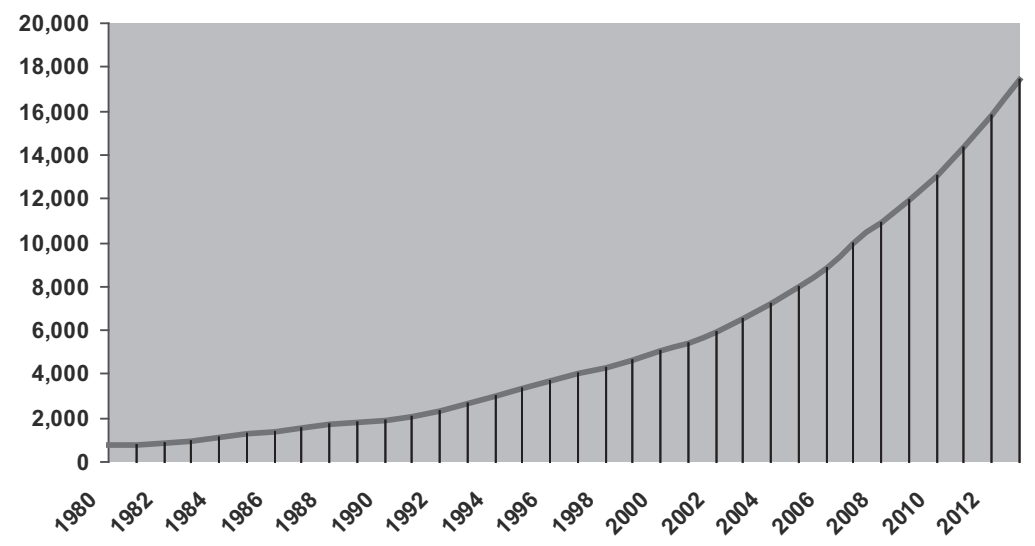

* China's GDP calculated based on constant prices. Levels for 2007 through 2010 are estimated.

Source: International Monetary Fund - World Economic Outlook Database, October 2008 
According to the World Development Indicators released in 2008, China is the second biggest economy based on purchasing power parity (The World Bank, 2008). China is also the largest recipient of foreign direct investment. China's rapid growth is caused by high foreign investment, a very large, young and cheap labor force, growing industrialization and high saving rates. The Chinese government is promoting China's industrialization in order to become a manufacturing base, producing and also assembling goods imported from other poorer Asian countries to sell to developed countries. China also produces technologically advanced products. In order to respond to its industrialization needs, China is becoming a large consumer of raw materials and especially energy resources. The Chinese government is also encouraging its companies to 'go global' (zou chuqu 走出去) and in fact, some Chinese companies, such as Huawei and Haier, are developing worldwide name recognition. Moreover, Chinese companies are also buying foreign companies, for example the Chinese-owned Lenovo bought IBM's PC division.

However, China is still a developing country and it must deal with severe problems such as the big inequalities between inland and coastal areas, between rural and urban China, growing unemployment, the inefficiency of state-owned companies, the inefficiency of its banking system, real estate speculation, corruption, counterfeiting, environmental degradation and large energy needs. To develop, China needs large quantities of coal, iron, steel, cement and especially oil. Since 2003, China became the second largest oil consumer in the world, ahead of Japan. China is also the largest consumer of cement, which is used in the construction of its huge infrastructure including the facilities for the Beijing Olympic Games.

Although at the national level the Chinese economy is growing very fast, there are still great inequalities within the country regarding development. In fact, only 38 per cent of the population lives in the wealthy coastal areas between Liaoning and Guangdong provinces, areas, which contribute 57 per cent of national GDP. The border regions of Tibet and Xinjiang represent 37 per cent of Chinese territory but the population in these regions produce only 2 per cent of the country's total GDP. About two thirds of the Chinese population live in rural areas. If China is to continue growing, the Chinese government needs to pay much attention to problems such as the regional economic inequalities, the growing unemployment, the corruption, the environmental degradation, and poverty. And indeed, it seems that this is happening in recent years. Chinese leaders adopted the so-called 'people first' (yi min wei ben 以民为本) approach, which suggests that the priority will be to satisfy the people's needs. 


\section{The concept of China's peaceful rise}

Some scholars argue that when countries become economic powers, they tend to focus on the development of military capability and may even use force against other countries. The historian Alan J. P. Taylor, who wrote one of the earliest books on great powers, said: 'The test of a great power is the test of strength for war' (Taylor I954). Later, in his book about the rise and fall of the most powerful countries throughout history, the so-called great powers, Paul Kennedy wrote: 'The triumph of any great power, or the collapse, is usually a consequence of long fight between armed forces' (Kennedy i987).

In China's case, its increasing economic power is reflected in its increasing military power. Specially in the last decade China has greatly increased its military expenditures. Every March, the Chinese government releases the figure for the country's national military expenditure. In March 2008, it was announced that China's military budget would rise I7.6 per cent, to 4 I7 billion yuan ( $€ 38.7$ billion) (Cit Lague 2008). Some analysts argue that these figures are not accurate or even reliable and most of them estimate that China's real spending on defense is at least three times greater than the publicly disclosed figure. The US Department of Defense delivers an annual report to the Congress that cites much higher figures for Chinese military spending: 2008's report mentions an expenditure of US\$I22 billion ( $€ 77.7$ billion). According to the Stockholm International Peace Research Institute, one of the most reliable research institutes on military expenditure, Chinese defense spending is in fact only slightly higher than official Chinese figures. According to this Institute's Yearbook, in 2007 China spent US $\$ 58.3$ billion on its military. According to this same report, the United States still has by far the world's largest military expenditure: US\$ 547 billion (45 per cent of the total) and it is now higher than at any time since World War Two.

The Chinese government justifies military expenditures by claiming that it is necessary for defense purposes; this is supported by all Chinese official policy papers on defense. Especially in the two last decades, Chinese leadership argues that it does not have violent purposes and will not use force in the relations to other countries, that it solely wishes to promote a much needed peaceful environment in the surrounding areas and also around the world. This line follows Deng Xiaoping's 1985 statement on what he considered to be the top driving principles of Chinese domestic and foreign policy: peace and development (heping yu fazhan 和平与发展). Recently and following the resurgence of 'China threat theory' among other countries after some events such as the Tian'anmen massacre and the Taiwan crisis in I995-96, the Chinese government adopted the 'new security concept' (xin an- 
quan guan 新安全观) and later on the concept of 'China's peaceful rise' (zhongguo heping jueqi 中国和平崛起). These concepts became top slogans in Chinese foreign policy and often appear in official speeches.

The so-called 'new security concept' was adopted during the Jiang Zemin leadership. It was first mentioned in the Russian-Chinese 'Joint Declaration on a Multipolar World and the Establishment of a New International Order', in 1997. Since then the Chinese leaders including the Chinese President, the Chinese Premier and the Chinese Foreign Ministry started to refer the need to adopt a new security pattern in the relation with other countries. In 1999, in the speech on the Conference on Disarmament in Geneve, the Chinese president Jiang Zemin explained that the new security concept should include four elements: mutual trust (huxin 互信), reciprocal benefit (huli 互利), equality (pingdeng 平等) and coordination (xiezuo 协作). In reality, through the "new security concept', Chinese leadership wants to gain other countries' trust, especially neighboring countries and the US, with the aim of promoting a peaceful environment so that it will continue to grow smoothly. The current Chinese government also endorses this peaceful approach. In order to overcome great domestic problems resulting from the Chinese rapid economic growth, such as regional inequalities, environmental degradation, poverty and unemployment, the so-called fourth generation of leaders including the Chinese president $\mathrm{Hu}$ Jintao and the Premier Wen Jiabao adopted the 'concept of scientific development' (kexue de fazhan guan 科学的发展观). This slogan was launched in 2004 and includes four aspects of development: human development, comprehensive development, coordinated development and sustainable development. Through this concept the Chinese government commits to promote the balance between rural and urban areas, between different regions, to solve economic and social issues, to solve environmental issues, and finally to support the domestic development and at the same time open up to the outside world. In practice the current government has been putting a great deal of attention on solving these problems arising from the quick growth rates and has adopted several policies to try to overcome them.

At an international level, China wishes to project an image of responsible power that should not be feared by other countries. Since coming to power in March 2003, the Hu-Wen leadership always speaks of their aims as being peaceful in official speeches to foreign leaders and in international organizations. Throughout 2003, there were some discussions at the Communist Party level on the kind of strategy China should adopt while pursuing its 'rise'. Capital Teachers University's Professor Qi Shirong and Nanjing University's Professor Qian Chengdan were invited to give a lecture to Politburo members on the history of the world's great powers after the fifteenth century (Cit Peng 2004). 
Afterwards the concept of 'China's peaceful rise' (zhongguo heping jueqi) was formulated by Zheng Bijian, at the time a member of the standing committee of the Chinese People's Political Consultative Conference and former vice principal of the Communist Party School. In the Bo'ao Forum for Asia 2003, he explained the path China should undertake on its 'rise': while participating in economic globalization, China should follow an independent, sovereign, peaceful and non-hegemonic path towards growth and development (Zheng Bijian, 2003). According to him, China is following a peaceful approach while emerging and should not be perceived as a threat by other countries. Based on China's foreign policy practice since I978, he argues that China will continue to follow a peaceful path, contrasting to other foreign countries such as Germany and Japan. Apart from peace, the other main feature of China's rise is the indepence.

References to this peaceful approach also started to appear in the governmental speeches. Chinese Premier Wen Jiabao referred to China's 'peaceful rise' in his speech at Harvard University, the following December. After describing China as a peaceful civilization throughout history, he explained China's strategy:

China is a very large developing country. It is neither proper nor possible for us to rely on foreign countries for development. We must and we can only rely on our own efforts. In other words, while opening still wider to the outside world, we must more fully and more conscientiously depend on our own structural innovation, on constantly expanding the domestic market, on converting the huge savings of the citizens into investment, and on improving the quality of the population and scientific and technological progress to solve the problems of resources and the environment. Here lies the essence of China's road of peaceful rise and development (Wen Jiabao 2003).

'China's peaceful rise' was also emphasized by President Hu Jintao that same month during a seminar commemorating the IIo $^{\text {th }}$ Anniversary of Mao Zedong's birth. Later, in the second session of the Tenth National People's Congress, in March 2004, the prime minister and the foreign minister again used this expression in press conferences. Wen Jiabao further explained the five aspects of the concept of 'peaceful rise':

China will take advantage of world's peace and endeavours to develop itself, it shall succeed by making use of its own efforts and based on its own strength whilst maintaining the open up policy and developing economic and trade exchanges with all friendly 
countries; this rise will take a long period of time and hard work of the people, and finally this rise will not represent an obstacle or threat to other countries (Wen Jiabao, 2004).

Since mid-May 2004 this expression began to appear less often in official speeches and almost disappeared. This change was encouraged by Jiang Zemin who still had some leverage in Chinese politics. ${ }^{2}$ He believed in the primacy of the military to ensure a prosperous and strong nation. So, according to him it was not completely accurate to use the expression 'peaceful rise'. This was especially true in the case of Taiwan, where Chinese leaders always admitted the possibility of using force to take the island back.

Furthermore, the word 'rise' may be considered incorrect. On one hand and according to some analysts such as Joseph Nye, the expression rise is not accurate: 'reemergence would be more precise since by size and history the Middle Kingdom has for long been a major power in East Asia. Technically and economically, China was the world's leader (though without global reach) from 500 to I500. Only in the last half-millennium was it overtaken by Europe and America' (Nye, 2005). On the other hand, the question remains whether China is currently a power that has already 'risen', having reached an overall development from economic, political and social point of view. It seems that China still has a long way to go and still needs to solve several domestic problems, while at the same time continuing to promote domestic development in other areas. It is more accurate to use the expression 'rising'.

Finally Chinese leaders often consider 'rise' to be a negative word often associated with hegemony, which they have always denied to be their final goal. Since the end of 2004, the government has started to use new less aggressive expressions such as 'peaceful development' (heping fazhan 和平发展), 'peaceful resurgence' (heping fuxing 和平复 兴) and 'peaceful rejuvenation' (heping zhenxing 和平振兴).

\section{Looking to China's culture and history}

If we analyse the Chinese traditional culture and history, we can consider the concept of 'peaceful rise' as deeply rooted in some Chinese ancient philosophies as well as the predominant government practice in the past.

For example, Confucius (55I-479 B.C.E.) spoke of principles such as 'harmony despite difference' (he er bu tong 和而不同) and 'harmony as the most precious value' (he wei gui 和为贵) (The Confucian Analects Lunyu, Chapter I-I2). This Chinese philosopher presented a humanist 
ethic of being and acting, not just within the family but also in society and within the context of the state. This ethic was based on a hierarchical relationship of respect. Each person should respect those deemed to be their superiors: subjects should respect the ruler, children should respect their parents, wives should respect their husbands, younger brothers should respect elder brothers and friends should mutually respect each other. If each person acted according to these rules of respect, then the society would be harmonious and the state perfect. Finally, peace and harmony are presented in the Chinese traditional culture as an ideal, maybe an utopia.

Also the Taoist philosopher Laozi ( sixth century B.C.E.) presented the universe as a whole in harmony, each part influencing the whole. So everyone would be in harmony with nature. He also introduced the ideal of wuwei (无为), which means non-action or letting life flow like a river, not fighting against the flow.

Another Chinese philosopher Mozi (480-390 B.C.E.) further opposed wars and presented an ideal of universal love within an egalitarian society founded on mutual support and devotion to common good.

Also a great military strategist Sunzi (fourth century B.C.E.), who wrote about the art of war, developed a whole strategy aimed at conquering the enemy without using force. This means that even in a violent context, the Chinese always considered diplomacy as the most important instrument of foreign policy, not war.

These philosophies were created during the Warring States period (475-22I B.C.E.) when the Chinese territory was divided into seven kingdoms that all fought against each other. These kingdoms' sovereigns would ask for advice on new strategies to conquer other states, that's why several philosophies and also military strategies came up during this period. As a result, this period came to be known as the period of 'a hundred schools of thought'.

The Chinese people has the capability to absorb different cultural values from different ethics and mix them in a more or less harmonious way. That idiosyncrasy allows the Chinese people to see the world as a whole, generally in harmony with nature but at the same time using the Confucian ethics when acting in the society. Harmony is then one of the main aims when acting in the relation with others.

In the relation with other countries, China has adopted a mainly peaceful foreign policy throughout history. Although China has fought off attacks from other people, such as the Xiongnu, Turks and Mongols, and even used force to conquer some territories, its behaviour has been mostly peaceful. Some examples of China's peaceful behavior in foreign policy were the use of a tribute system, the use of the silk route and the use of diplomacy during the maritime travels of Zheng He. 
After violently conquering other kingdoms under Qin Shihuangdi's rule, this short dynasty gave way to a more prosperous and peaceful one. It was during the Han dynasty (206 B.C.E.-220) that China reached a very high level of development and established relations with neighboring kingdoms through the 'tribute system'. The 'tribute system' was based on the neighboring countries' recognition of China as a superior civilization and thus they granted a tribute; consequently, the Middle Kingdom gave these countries protection while respecting their independence. Through this peaceful system, China established regular diplomatic relations with its neighbors. The tribute system is related to the idea of 'all under heaven' (tian xia 天下), which means that all kingdoms should be in harmony under heaven. Since the Chinese emperor was considered by the Chinese to be the representative of Heaven on Earth, all other kings in neighboring kingdoms were seen to owe him respect. While this system was in effect, there was a kind of pax sinica in the region. This system was improved throughout the centuries and in the Ming dynasty (1368-1644) it reached its most developed stage.

Also during the Han dynasty, the Chinese emperors used the economic flows to promote peaceful relations with neighboring countries. Although there were some problems between China and some northern kingdoms, through the route of silk, the Chinese emperors improved the relationship with these countries and build alliances. In fact, it was in a diplomatic attempt to find allies during the Han dynasty that Zhang Qian accidentally discovered the silk route in the year I39. This emperor's envoy realized the importance that the silk trade had for the relationship between the Chinese and the peoples of Central Asia and persuaded the emperor to support this trade. Therefore, there was an improvement in the trade relationships but also in the political and cultural relationships with these peoples. The silk route was particularly prosperous during the Tang dynasty (6I8-907); during that time also other trade routes developed. China became very prosperous and cultural exchange between China and other countries prospered.

Later, during the Ming dynasty, China used diplomacy as the main instrument of the foreign policy to establish relations with an even broader range of countries and peoples. In I405, Emperor Yongle nominated Zheng $\mathrm{He}$ as the chief diplomat and the admiral of a great fleet on exploratory missions to the western world. Between I405 and I433, he carried out seven missions throughout the oceans to several places in Southeast Asia, the Indian Ocean, the Persian Gulf, the Red Sea and the East African coast. For the Chinese Emperor, the goal was to establish diplomatic relations with other territories. Through these trips, China established peaceful contacts with Asian and African peoples, as well as commercial and cultural links. In these contacts, the 
Chinese would make valuable offers to the peoples they meet. This means that the Chinese emperor privileged peaceful contacts instead of force.

During Chinese history, there were also some violent events especially in conflicts with non-han people and when China expanded its territory. However, during most of its history China has been a peaceful country in its relation with other countries.

\section{Will China rise peacefully?}

Currently the question remains: if China is advocating peace, why does it need a strong military? Beijing follows the principle of 'prosperous nation, strong military' (fuguo, qiangbing), which means that it does not see peace and military strength as mutually exclusive. The Chinese government advocates a strong military for defense purposes. According to the decision taken in the fifteenth study session of the Politburo Standing Committee in July 2004, the strategy adopted should be to 'prepare for war while talking about peace' (nengzhanfang, nengyanhe 能战方能言和). In essence, the strategy is to use the act of preparation for war as a way of disuasing war itself.

As mentioned above, some scholars believe that a country that is an economic power tends to strengthen its military power so that it has the ability to defend itself. Indeed the Chinese government has stated that when feeling threatened, it will defend itself and eventually use force. Some of the situations in which Beijing may use force are related to sovereignty claims, such as those involving Taiwan and other territories in the South China Sea. These claims may be considered as evolving a question of 'face' for China, the perception of its prestige in the eyes of others. During the nineteenth century, the so-called century of shame and humiliation, China lost its sovereignty over some territories. The current Chinese government does not want that to happen again and admits using force to avoid this, if it deems it necessary. This approach of the Chinese government is the so called defensive realist one, which means that they are preparing the military to prevent losses, not to conquer world power as offensive realists would aim to do. The Chinese government's stated intention is not to threaten other countries.

Nevertheless, in recent years there has been a resurgence of belief that China poses a military threat to other states, especially among neighboring countries. This belief is prompted by China's military expenditures, its political system and its strong nationalism. China, with its 9.5 million square kilometers, is the biggest country in the region and the most populated country in the world with I.3 billion inhabi- 
tants. This may cause suspicion and also fear among smaller neighboring countries, particularly when the government announces increases in military expenditures. In the mid-I990s, these suspicions reached a high level when China undertook military exercises in the Taiwan Strait following Taiwan's getting closer to the US and Taiwanese presidential elections. Beijing's behavior caused fear specially among neighboring countries.

Furthermore, the idiosyncrasy of China's political system with authoritarian features and lack of fundamental rights motivates distrust among western democratic countries. In recent years, there has also been an increase in nationalism among Chinese people living inside China. In some cases, this nationalism has gotten out of control and caused riots against foreign countries such as the US and Japan. Two of the most important demonstrations of national pride among the Chinese people in recent years occurred in 1999 against the US, following NATO's supposed accidental bombing of the Chinese Embassy in Belgrade and in 2004 against Japan due to its plan to play a more active role in the international system which reminded the Chinese people of the aggression they had suffered at the hands of Japan in the past. In these two cases, the Chinese people's pride was hurt. In order to take place, these riots must have official authorization, which means that they were allowed by the Chinese government. These nationalist protests may be seen as a strategy from the government to unify the Chinese people in order to fight a perceived foreign threat. Consequently, people's attention is drawn away from domestic issues.

One of the countries, which sees China as a threat, especially as a threat to its position as sole superpower, is the US. The US government regularly criticizes China for its military spending and questions its stated peaceful intentions. The US defense secretary Donald Rumsfeld once argued that China's military spending threatens not only Taiwan and the US but also the delicate security balance of Asia (Cit Shanker 2005). Also the international relations expert from the University of Chicago John Mearsheimer doubts China can rise peacefully and predicts that 'the United States and China are likely to engage in an intense security competition with considerable potential for war' (2005: 47). However, the relationship between China and US is irregular floating between mutual criticism and cooperation. Although China supported the US 'war on terrorism', Washington continues to sell weapons to Taiwan, which continues to angry China. The US government continues to press Beijing to change the political system, to respect more human rights and to promote changes in the economic and monetary system. These moves may be seen as a way to slow down China's growth and prevent it from becoming a political power in the region and in the world. However, too much pressure can make 
China feel uncomfortable and become more dangerous. As Henry Kissinger advises, containment is not going to work because the challenge China poses for the medium term future will, in all likelihood, be political and economic, not military' (Kissinger 2005). A better engagement of China in the international system may be the best choice because it will make Beijing less eager to use force and the US as the world's superpower has a major role in this task.

The Chinese government always emphasizes that China follows a peaceful behaviour in the international system. While rising and growing in terms of its economy, it will do it in a peaceful way not representing a threat to other countries. The Chinese leaders often refer to the violent path followed by other countries seeking power throughout history, such as Germany and Japan, as a bad example that China wants to avoid. They argue that China is not seeking hegemony or a violent way to increase its power. According to the Fudan University Professor at the Center for American Studies Wang Yiwei, the strategy of the emerging China has three elements: rise of peace, rise by peace and rise for peace (Wang 2004). The rise of peace means that the growth of China derives from a peaceful environment; the rise by peace means that China has created a cooperative model of relationship with other countries; and the rise for peace is related to the purpose of promoting world peace and prosperity through its peaceful path in foreign policy.

China's model for its own emergence can be seen as a closed cycle in which China's growth is motivated by the international peaceful environment, which prompts Asia's growth, which stimulates world growth, inspiring an international peaceful environment. This is why the Chinese government uses the 'peaceful rise' slogan spreading the image of a responsible and peaceful country not to be feared by others.

The Chinese government seeks to demonstrate that its growth in economic, cultural and political power benefits its neighboring countries and the world in general; this position is based on a notion of common prosperity, a 'win-win' game. According to chart 7.2, China will only grow and develop in a peaceful international environment. This will be a catalyst for Asian economic growth and ultimately the world's growth. Ultimately, China needs a peaceful environment. As China becomes more integrated in the Asian and international economic system, it will represent less threats to other countries. The slogan of China's peaceful rise was designed to limit Asian countries' apprehension about China intentions in the region. The purpose of the Chinese government for spreading the 'peaceful rise' slogan, is to inspire a reciprocal behavior from other countries, and in the long-term maybe get some support against the US. China expects neigboring countries to come closer and to support it in some international issues. 
Through strategic relationships and multilateral agreements, China is creating a kind of buffer zone around its borders to protect itself from the US. Also China has moved closer to the European Union, the current major trade partner, looking for ways of cooperating in several fields such economy and technology. This is a feature of its cooperative behavior.

Chart 7.2 Chinese model for rise
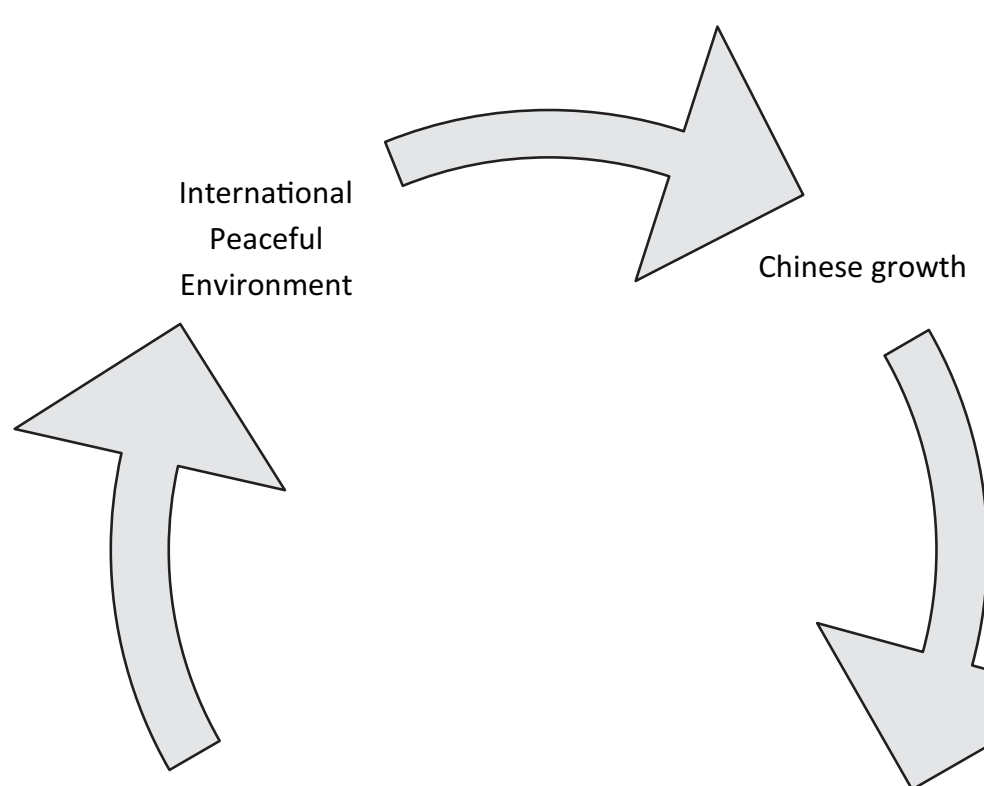

World Growth
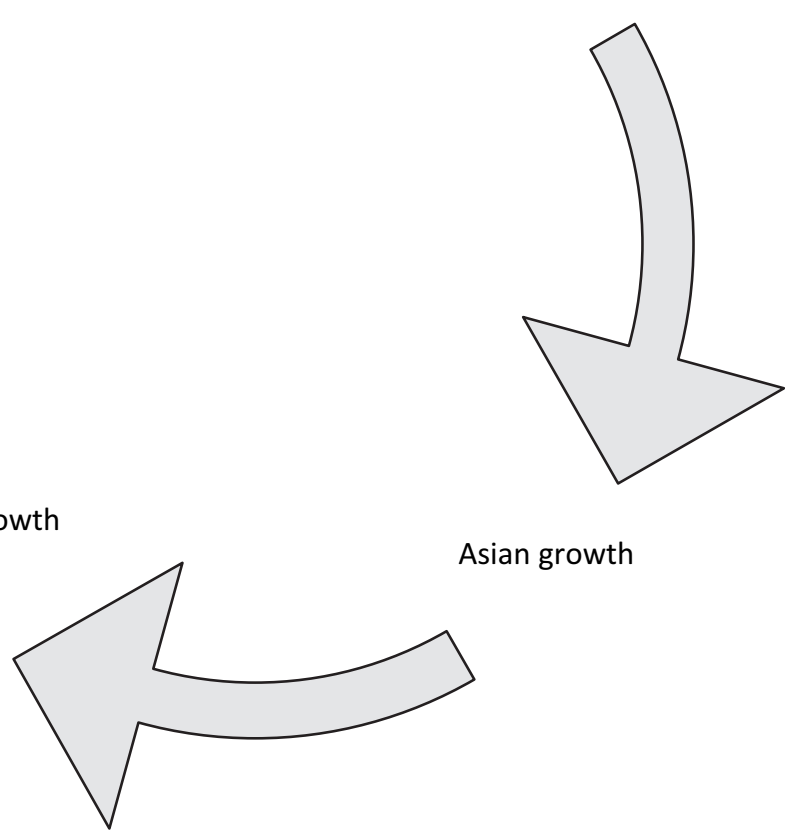

But as the commentator on Chinese affairs Frank Ching observes, 'Beijing must realize that the world will not just listen to its words but will be watching its actions as well' (Ching 2004). And what has Beijing been doing? 


\section{China's emergence path}

Like a real great power, China has become a more active player in the international system. China is deepening its relationships with several countries all over the world, assuming an active role in world affairs and developing partnerships with some major international players. Current Chinese foreign policy is driven by three major components: first, economic diplomacy, then comprehensive and cooperative security, and finally the so-called soft power. For the reasons mentioned before, Chinese behavior has been mainly non-aggressive.

Since the end of the cold war, China's priority has been the economic growth. In the foreign policy, the Chinese government started to use its diplomacy to promote economic development. All over the world, China essentially looks for markets for their products and new sources of investment, resources and technology. Therefore, economic diplomacy not only includes trade, but also investment and economic aid. China has been successful in this matter maintaining a positive trade balance and receiving increasingly large amounts of foreign investment and aid. In 2007, China's total foreign trade reached US\$2,I74 billion and the trade balance was positive for China in more than US\$ 262 billion. China has several trading partners; the three main partners are the EU, US and Japan. After the 2004 enlargement, EU became China's largest trading partner, ahead of the US and Japan. Regarding investment, the most important investment partners are Asian countries, countries with whom China has historic relationships. In recent years, China has itself increased its investment abroad following the 'go global' (zou chuqu) policy adopted by Jiang Zemin in 1998 .

Since Chinese government priority is the economic development, a secure domestic and international environment is essential to guarantee it. Since the end of the cold war, Chinese security is mainly cooperative. Cooperation is the base of the strategy proposed by Deng Xiaoping in I984 of 'putting disputes aside and promote joint development' (gezhi zhengyi, gongtong kaifa 搁置争议共同开发). Cooperative security (hezuo anquan 合作安全) is defined by the Chinese government as the ideal way to deal with security issues, including a peaceful settlement of disputes, as well as consultation and coordination on issues of mutual concern to prevent conflicts. Although previously reluctant to assume an assertive practice in security affairs, the Chinese government has changed its behaviour since the end of the cold war. It has gradually been adopting a more active and cooperative attitude in security issues in relation with other countries and also in international organizations and forums. This behavior is one of the features of a great power, which means China is gradually assuming the role of a great power in the international system. In practice, the Chinese gov- 
ernment has actively participated in discussing and promoting talks in regional affairs and it got involved in regional forums and organizations. Examples of this behavior include the hosting of the six-party talks on North Korea nuclear program since 2003 and the participation in regional and international forums and organizations such as the Shanghai Cooperation Organization, ASEAN Regional Forum, and the UN.

Apart from cooperation as its modus operandi, since the end of the cold war, Beijing has also adopted a more comprehensive concept of security: zonghe anquan 综合安全. To respond to emerging transnational security threats not limited to traditional military issues, states need to adopt a broad perspective of security and must cooperate with other states to solve them. These transnational threats particularly affect East Asia; they include terrorism, environmental deterioration, diseases, contraband, drug trafficking, and piracy. To respond to these threats, states need a holistic security concept including economic security, environmental security, social security, etc. The Chinese government has adopted a 'comprehensive security' concept, which includes non-traditional security. Cooperation is the preferred method to solve these issues.

China still has several unsolved security issues mainly related to sovereignty, such as Taiwan and some islands in the South China Sea and in the East China Sea. Although cooperation is recognized as the best method to solve these disputes, Beijing does not deny the possibility of using force. As mentioned above, these territorial issues invoke the concept of face and China's desire to not loose perceived prestige again.

Finally, the last feature of China's rising power is soft power. Beijing is learning how to use soft power to earn foreign countries' trust. According to Joseph Nye, the soft power is a co-optative power, an ability to change what others want, which may be supported by culture attractiveness and values or by the ability to manipulate political agendas (Nye 2004). In fact, the Chinese government is doing that. In recent years, Beijing is dedicating resources to actively spreading Chinese language and culture through a network of Confucius Institutes, which are opening up all over the world. Beijing is also promoting its development model among developing countries. Beijing is after all using its soft power to build relations with different countries all over the world and win their trust.

This strategy has allowed China to become a great power. The path to becoming a superpower is open. Although Beijing never admits its desire to become a world leader, in fact it is achieving a key place in world politics. This is part of a strategy of tao guang yang hui, (蹈光养 䀲) which means hiding one's talents until the right moment comes. 
The question is whether China's increase in power will make it a superpower or not. In my opinion, it will not. To become a superpower China would need to reach a leadership place among other countries in different fields such as economic, political, military and cultural. It is true that China is growing very rapidly and its economy has attained very high levels. China's economy is half the size of the US's economy, and according to the predictions before the financial crisis of the last year, if it continued to grow annually by 6 per cent, while the US grows by 2 per cent, China's economy would catch up with the US's after 2025. Nevertheless, China still has major problems to solve in the economic, social and financial fields. In spite of this fact, I believe that in the long term, China will get a top position among the world's most powerful countries in the economic field and will use funds to modernize its military, becoming a military power. The Peking University Professor Pan Wei argues that China needs military to get peace not to rise (Pan 2004). This is a relative power, meaning China's power is relative to world's present situation, it should encounter other countries' power.

Although China may reach a high economic and even military level, I do not believe it is possible for China to become an overall superpower. To be a superpower China should have enough power in several areas so as to influence world economy, politics and culture. I do not think that is going to be possible either in the near or in the far future. First, I do not believe the Chinese political system is going to be adopted as a model by other countries in the world; it is too specific. China's political and economic model includes elements of its culture and political ideology; it is a model with Chinese characteristics. It ultimately results from China's idiosyncrasy. The political system may be adopted by countries that are culturally close to China, and the economic model may be adopted by developing countries. However, I don't believe that these models may be adopted worldwide. Furthermore, as far as Chinese culture is concerned, it may be close to that of other Asian countries that also follow Confucianism but not to other countries throughout the world. Chinese movies, art and language are becoming popular worldwide but not as popular as US 'culture'.

China may be considered a great power with great economic power and eventually great military power in the future. But it won't be a complete superpower as the US is today.

Chinese leaders also refuse to consider themselves as leaders in world politics. They often use the principle ' $b u$ dang tou' (不当头) which means not to assume a leadership role. Beijing leaders fear that if they would admit the desire to become a hegemonic power, this could generate fears among other countries and negative reactions, which Beijing wants to avoid. Due to China's growing economic power, 
there have been some sinophobic reactions among European countries and the US. Beijing wants to avoid these reactions.

On the other hand, the international system has changed and today it is very difficult for a single country to achieve the status of a superpower. There are checks and balances to prevent one single superpower from consolidating too much power and ultimately to prevent a violent competition with the current single superpower. In addition, I believe the US would not allow the emergence of a superpower, which would mean its defeat.

For the future, I believe we can expect China to growth in a mainly peaceful manner. With the status of a great power, China's foreign affairs will continue to follow its three major driving forces: economic diplomacy, comprehensive and cooperative security and soft power.

\section{Notes}

I Just to name a few foreign scholars' articles and books: Vogel, Erza (2004); Nye, Joseph S. (2005); Economy, Elizabeth (2005); Sutter, Robert G. (2005); Ross, Robert S. (2006); Shirk, Susan L. (2007). The Peterson Institute will soon publish a book on the challenges and opportunities of China's rise by Fred Bergstein, Charles Freeman and Nicholas Hardy. Chinese academics have also been discussing these issues. See for example Yan, Xuetong (I998 and 200I); Xu, Chengfang (200I); Liu, Jie (2004); Pan, Wei (2004); Peng, Peng (2004); the theorist of the China's peaceful rise Zheng Bijian (2005) and Hu Angang (2007). In 2007, a Chinese scholar and an American scholar, Zhu Feng from Peking University and Robert Ross from Boston College, coordinated a book on China's rise, both in theory and practice that was published in Shanghai and is forthcoming from Cornell University Press under the title China's Ascent: Power, Security and the Future of International Politics.

2 Until September 2004, Jiang Zemin still had some influence in Chinese politics, but at that time he stepped down as leader of the Central Military Commission.

\section{References}

'China's National Defense in 2004' (2004), People's Daily Online, December < http://english.people.com.cn/whitepaper/defense2004/defense2004.html>.

Chang, Gordon (200I), The Coming Collapse of China. London: Arrow Books.

Ching, Frank (2004), 'Actions speak louder than words', February, 25, South China Morning Post. < http://archive.scmp.com/showarticles.php>.

Deng, Xiaoping (1982-1992) 'Peace and Development are the two outstanding issues in the world today', Selected Works of Deng Xiaoping, vol. III.

< http://web.peopledaily.com.cn/english/dengxp/vol3/text/cr330.html>.

Economy, Elizabeth (2005), 'China's rise in Southeast Asia: Implications for the United States'. Journal of Contemporary China I4 (44), August: 409-425.

$\mathrm{Hu}$ Angang (2007), Zhongguo heping zhi lu (The roadmap of China's Rising). Beijing: Peking University Press (Beijing Daxue Chubanshe). 
International Monetary Fund (2008) - 'World Economic Outlook Database', October. $<$ http://www.imf.org/external/pubs/ft/weo/2008/o2/weodata/weorept.aspx? $\mathrm{sy}=\mathrm{I} 980 \&$ ey $=20 \mathrm{I} 3 \& \mathrm{scsm}=\mathrm{I} \& \mathrm{ssd}=\mathrm{I} \& \mathrm{sort}=\mathrm{country} \& \mathrm{ds}=. \& \mathrm{br}=\mathrm{I} \& \mathrm{c}=924 \& \mathrm{~s}=\mathrm{NGDP} \_\mathrm{R} \%$ 2CNGDP_RPCH\%2CNGDP\%2CNGDPD\%2CNGDPRPC\%2CNGDPPC\%2CNGDPDPC $\% 2$ CBCA\%2CBCA_NGDPD\&grp $=0 \& a=\&$ pri. $x=84 \&$ prr.y=8\#download $>$.

Kennedy, Paul (1987), The Rise and Fall of the Great Powers: Economic Change and Military Conflict from 1500 to 2000. New York: Random House.

Kissinger, Henry (2005), 'China: Containment Won't Work', The Washington Post, June I3. $<$ http://www.washingtonpost.com/wp-dyn/content/article/2005/06/12/ AR200506I201533.html>.

Lague, David (2008), 'Chinese Military Spending Rises Sharply', International Herald Tribune, March 5 < http://www.iht.com/articles/2008/03/05/asia/05china.php>.

Lee, Kwan Yew (2005), 'Win-win Approach for China's Peaceful Rise', April 23, <http:// www.boaoforum.org/ziliao/200505/13/t20050513-3826760.htm>.

Liu, Jie (2004), Jizhihua shengcun - Zhongguo heping jueqi de zhanlue jueze (Regimenazation: The Strategic Choice in Course of China's Peaceful Rise). Beijing: Shishi Press (Shishi chubanshe).

Lun yu (The Confucian Analects), (1992) Changsha: Hunan Press (Hunan chubanshe).

Mearsheimer, John J. (2005), 'Better to be Godzilla than Bambi'. Foreign Policy Special Report, January/February. <http://www.carnegieendowment.org/publications/index.cfm?fa=view \&id=I6538\&prog=zch\&zoom_highlight=Better+to+Be+Godzilla+than+Bambi+>.

Mosher, Steven W. (2000), Hegemon: China's Plan to Dominate Asia and the World. San Francisco: Encounter Books.

Nye Jr., Joseph S.(2004), Soft Power: The Means to Success in World Politics. New York: Public Affairs.

Nye, Joseph S. (2005), 'China's 'Peaceful' Rise?’ China’s Peaceful Rise, Les Cahiers du débat, May.

Pan, Wei (2004), 'Guanyu zhongguo de heping jueqi' (On China's peaceful rise). (unpublished).

Peking University website March, I7. < http://www.sis.pku.edu.cn/pub/panwei/Document View.aspx? Id=3094>.

Peng, Peng (ed.)(2004), Heping juegi lun - zhongguo zhongsu daguo zhi lu (Peaceful Rising Theory - The Path of China becoming a Great Power). Jinguan, Guangdong: Guangdong People's Press (Guangdong renmin chubanshe.)

Ross, Robert S. (2006), 'Balance of Power Politics and the Rise of China: Accomodation and Balancing in East Asia'. Security Studies 3, July-September: 355-395.

Shanker, Thom (2005), 'Rumsfeld Issues a Sharp Rebuke to China on Arms', The New York Times, June 4. <http://www.nytimes.com/2005/06/04/international/asia/o4rumsfeld. html?th\&emc $=$ th $>$.

Shirk, Susan L. (2007), China: Fragile Superpower: How China's Internal Politics Could Derail its Peaceful Rise. New York, Oxford University Press.

SIPRI - Stockholm International Peace Research Institute Yearbook 2008 - Armaments, Disarmament and International Security summary, Sweden: Elanders, 2008. <www.sipri. org $>$.

Sun Zi (1995), The Art of War. Beijing: People's China Publishing House.

Sutter, Robert G. (2005), China's Rise in Asia: Promises and Perils. Lanham, Maryland: Rowman \& Littlefield Publishers.

Taylor, Alan J. P. (1954), The Struggle for Mastery in Europe 1848-1918. Oxford: Clarendon.

The World Bank (2008), 2008 World Development Indicators, Washington: International Bank for Reconstruction and Development/The World Bank, April.

Vogel, Erza (2004), 'The Rise of China and the Changing Face of East Asia'. Asia-Pacific Review, II(I): 46-57. 
Wang, Yiwei (2004), 'The Dimensions of China's Peaceful Rise', May, I4, Asia Times <http://www.atimes.com/atimes/China/FEr4Ado3.html>.

Wen, Jiabao (2003), 'Full text of Premier Wen's speech at Harvard', December, I2, People's Daily Online, <http://english.peopledaily.com.cn/2003I2/I2/eng2003I2I2_I30267. shtml>.

- (2004), 'Full text of Chinese premier's press conference', March, I4, People's Daily Online, <http://english.peopledaily.com.cn/200403/I5/eng200403I5_I37493.shtml>.

$\mathrm{Xu}$, Chengfang (200I), Heping Fanglue - Zhongguo Waijiao Zhengce Yanjiu (Peaceful General Plan - Research on Chinese Diplomatic Tactics). Beijing: Shishi Press (Shishi chubanshe).

Yan, Xuetong (et al.) (I998), Zhongguo jueqi - Guoji Huanjing Pinggu (International Environment for China's Rise). Tianjin: Tianjin People's Press (Tianjin Renmin Chubanshe).

Yan, Xuetong (200I), 'The Rise of China in Chinese Eyes'. Journal of Contemporary China, Io (26): 33-39.

Zheng, Bijian (2005), 'China's Peaceful Rise and New Role of Asia', April 24, < http://www. boaoforum.org/ziliao/200505/13/t20050513-382606r.htm>.

- (2003) 'A New Path for China's Peaceful Rise and the Future of Asia'. <http://www.brookings.edu/fp/events/200506r6bijianlunch.pdf>.

- (2005), 'China's «Peaceful Rise» to Great-Power Status'. Foreign Affairs, September/October: $18-24$.

Zhu Feng and Ross, Robert (Luobote Luosi) (2007), Zhongguo jueqi - Lilun yu Zhangce de shijiao (China rise: theory and policy point of view). Shanghai: Shanghai People's Press (Shanghai Renmin Chubanshe). 



\section{A Snapshot of Internet Regulation in Contemporary China: Censorship, Profitability and Responsibility}

Jinqiu Zhao

As one of the few developing countries performing well overall on the indicators for the Millennium Development Goals (MDGs) set by UNDP, China has been enjoying the fastest sustained economic advance in human history, with its GDP growing at an annual rate of 9.67 per cent from 1978 to 2006 . The liberalized economic environment and the information revolution have become the foremost drivers of China's fast telecommunication development in the last ten years. On April 20, 1994, China opened a $64 \mathrm{~K}$ international dedicated circuit to the Internet through Sprint Co. of the United States, realizing a fullfunctioning linkage ('Evolution of' 2003). With the installation of advanced network technology driving Internet penetration across the metropolitan areas, China's government is determined to extend Internet Protocol (IP) connectivity and make the Internet a tool to boost the nation's economy.

With the government drive, the Internet in China is undergoing phenomenal growth. It has revolutionized the ways Chinese communicate and interact. After modest beginnings in the mid-I99os, the number of Internet users ${ }^{\mathrm{I}}$ jumped from 0.62 million in 1997 to 210 million by December 2007, ranking China second in the world in terms of Internet users (CNNIC I997; CNNIC 2008). In 2007, there were about nine million domain names registered under ' $c n$ ' (shorthand for China as a country code) and I.5 million websites in China (CNNIC 2008).

The Internet remained unregulated during the emerging years of the technology in China. The first set of regulations on the Internet was formally announced in 1996 and in the ensuing years several laws were passed to tighten the government's control over the Internet. The October 2000 legislation is concerned with the involvement of foreign investments in the Internet sector and the responsibility of Internet service providers (ISPs) over their websites. A month later, another important legislation regarding news content and discussion forums was 
implemented. The December 2000 legislation specified that 'spreading rumors, defamation or publishing harmful information, inciting the overthrow of the country's government, the socialist system or a division of the country' should be deemed as cyber crime or cyber dissidence ('Review of China' n.d.: 2).

As many as I2 government agencies in China are involved in censoring the Internet, though their powers may vary, including the General Administration of Press and Publication (GAPP), the State Administration of Radio, Film and Television (SARFT), the Ministry of Information Industry (MII), the State Council Information Office (SCIO), the Central Propaganda Department (CPD), the Ministry of Public Security (MPS), the State Secrecy Bureau (SSB) and China's judiciary.

The Chinese government has taken a pragmatic approach towards regulating the Internet. Guided by the principle of 'guarded openness', the government on the one hand seeks to benefit from the economic advantages offered through openness to global information, on the other hand it intends to guard against the harmful influences that they believe the web may have upon social values and national integrity.

Nevertheless, the effective regulation of Internet content remains a formidable task to the Chinese government, given the vast possibilities of information exchange enabled by digital media and the apparent deficiencies in legislative control. This study selected two controversial issues confronting the Chinese government - news copyright and online satire. Through reviewing and evaluating China's attempts at regulating the Internet regarding the abovementioned issues, this research effort aimed to highlight an underlying tension in the current policies of the Chinese government, which promote a more open market economy while maintaining tight censorship over news media and freedom of speech, and aimed to consider the socio-economic implications of Internet censorship on media, society and people in China.

\section{News copyright}

The SCIO and MII are the two main government agencies responsible for administering the operations of domestic websites that engage in posting news. 'The Interim Provision on the Administration of Internet Web Sites Engaged in News Posting Operations' issued jointly by the SCIO and MII in November 2000 prescribes the following (CECC 2006):

Article 5: The legally established websites of central news units, news units of all departments of the central government's agencies and the news units directly under the provinces, autono- 
mous regions and independent municipalities and the municipal people's governments for the provinces and autonomous regions ('news websites') may engage in news posting operations after receiving authorization. Other news units may not independently establish news websites, but after receiving authorization may establish news web pages and engage in news posting operations on the news website established by a central news unit or a news unit of a province, autonomous region or independent municipality.

Article 7: Non-news units that establish general interest websites ('general interest non-news unit websites') that possess the qualifications set forth in Article 9 of these Provisions, may engage in operations of posting news promulgated by central government news units, the news units of departments of central government agencies, and the news units directly under the provinces, autonomous regions and independent municipalities, but may not post news from their own sources or news from other sources. Other Internet websites that are established by a non-news unit in accordance with the law may not engage in news posting operations.

Article 8: General interest non-news unit websites that engage in news posting operations shall, in accordance with Article 7 of these Provisions, after receiving examination and approval from the people's government information offices for the provinces, autonomous regions and independent municipalities, submit to examination and verification by the SCIO.

Given these Provisions, the SCIO keeps a tight control of licensing news websites as well as the legalization of the sources of news feeding those general interest websites. In general, news information websites must be part of the official media system, and must register with the government in order to begin operation. The Provisions envision a system in which most news websites are extensions of currently-existing news units, thereby the setting up of news websites has been exclusively restricted to the news units of government agencies both at the central and local levels. Non-news websites are deprived of the possibilities of doing their own reporting and they may only post news from news units officially acknowledged by the SCIO.

One of the most recent sets of regulations is the 'Provisions on the Administration of Internet News Information Services', issued jointly by the SCIO and the MII in September 2005. As compared to the 2000 Interim Provision, the 2005 Provisions range from the establish- 
ment, regulation and supervision of Internet news information service work units to the legal duties and administrative penalties for violation of any part of the Provisions. Superseding the division of news websites and non-news websites in the 2000 Interim Provision, the Internet news information service work units have been categorized into three types: Internet news services established by news work units that post news information which has already been published or broadcasted by the same news work units, Internet news services established by news work units that post news information beyond that which the same news work units have already published or broadcasted, and Internet news services established by non-news work units. What's more, the new Provisions set strict restrictions on the involvement of foreign forces and stipulate that any ventures with foreign investment are prohibited from engaging in providing Internet news information services (CECC 2006).

With regard to the source of information, the Provisions allow the Internet news services to reprint and transmit news issued by the existing news work units officially acknowledged by the central and local government, provided that the sources of information should be clearly denoted and the contents of news should not be distorted. For those Internet news services established by non-news work units, they may not post news they have gathered or edited themselves, and those breaking the rules are subject to a fine between RMB 5,000 and 30,000 (US\$ 625-3,750).

Limited to reprinting news stories generated by other media outlets, the overwhelming majority of the commercial websites have to turn to print media for news content. As a result, online news in China is more or less equivalent to 'online digest' (Bi 2006). Since the reposting of media content has by and large become permissible under the Provisions, most Internet news services select material from Chinese newspapers and other media outlets as they see fit, and payment for such reuse is typically symbolic or entirely absent.

Since the emergence of the commercial Internet portals in I996, the Chinese print media have been handing over the news that they gathered to the major Internet portals that featured news almost for free. However, it took almost a decade for the print media to realize that what they had offered up to the portal websites was not only news information, but also advertisers and audiences. According to research conducted by the China Renmin University Media Management Research Institute, the total revenue of the newspaper industry in the first half of 2005 was decreasing, with advertising revenue falling between ten per cent to 30 per cent, and some newspapers by more than 40 per cent (Liu 2006). 
Alarmed by the aggressive challenge, some newspapers started to launch a collective counterattack by forming an alliance to ban Internet websites from using their content gratis. The chief editors attending the 2005 Chinese Metropolitan Newspapers Chief Editors Study Annual Conference in Nanjing concluded with a 'Nanjing Declaration'. The core content was that they 'will no longer tolerate the commercial websites from using print news products for free' (Liu 2006 and Wu 2006).

Shortly afterwards, at the I2th Innovations and Developments in Newspaper Enterprises Forum in Guangzhou held in January 2006, the Liberation Daily Group (the Shanghai Communist Party's flagship newspaper) appealed to the 39 party newspaper groups in the country to form a national newspaper content alliance and raise the threshold for Internet reposting in order to safeguard their intellectual property rights (Liu 2006 and Wu 2006).

Despite the outcry over the apparent infringement of news copyright, there seems to be a lack of enthusiasm about the boycott attempt among other major newspapers. They suspect that a lot of noise is being made without specific action and the Nanjing Declarations have not been and are not expected to be implemented in practice (Liu 2006 and $\mathrm{Wu} 2006)$.

\section{Online satire}

With the growth of an affluent middle class in China, young Chinese consumers are not especially concerned with politics, but are enthusiastic about participating in websites that give them opportunities to express their thoughts and opinions regarding lifestyles and trends. For instance, some surfers prefer popular sites that allow diners to post restaurant reviews while others often visit those recording amateur singers' efforts and ranking them according to users' responses.

Likewise, the spoofing culture, called e-gao in Mandarin, has started to emerge as the most popular form of online satire, passionately embraced and widely followed by young 'netizens'. The exemplar is the online trailer for MURDER CAUSED BY A BUN produced by blogger and freelance filmmaker, $\mathrm{Hu}$ Ge. The 2o-minute video appeared on the Internet in early 2006 as a parody of Chen Kaige's (the Oscar-nominated director of I993's FAREWELL MY CONCUBINE) latest movie THE PROMISE. The spoof was intended to criticize the Chinese film industry monopoly and the loss of local character under the influences of the international market. It is no surprise that THE PROMISE did not deliver satisfaction to viewers as promised by its promotional campaign. It is also 
no surprise that $\mathrm{Hu}$ Ge gained huge support when Chen Kaige wanted to sue him for piracy.

The official attitude towards the spoofing craze at the very beginning of its emergence remained relatively tolerant as it took time to dissect and understand its political and social implications. An article titled 'Parody can help people ease work pressure' in China Daily ${ }^{2}$ depicts spoofing as 'a popular subculture that deconstructs serious themes to entertain people with comedy effects... that is characterized by humor, revelry, subversion, grass-root spontaneity, defiance of authority, mass participation and multi-media high-tech' (Huang 2006).

However, spoofs soon become the target of Internet censorship as they begin to touch on political and historical figures. A recent example of the trend was a video called 'Sparkling Red Star: Pan Dongzi Competing in Singing Contest' using clips from the I974 patriotic film about the Chinese revolution SPARKLING RED STAR. The video dubbed the movie clips to tell the story of a boy competing in the I2th CCTV (China Central Television) singing contest. In the ten-minute video, Pan Dongzi, the hero of the I974 movie, entered the CCTV singing contest to gain fame. The evil landowner became a foolish judge in the contest. Pan's father changed from a peasant in the original movie to a Beijing real estate tycoon. The video also mocked the quiz section of the CCTV singing contest and the winners' instant fame.

The short film about the singing contest incurred severe criticism. Some commentators believe satire should not go too far and the distortion of heroes and China's revolutionary history is immoral and unacceptable (Xinhua News Agency 2006). According to the Beijing News, SARFT plans to issue a new set of regulations to monitor video content on the Internet in the wake of a surge in short satirical films online. Video clips will have to be registered with SARFT before they are published on the Internet. Listed Internet companies such as sina.com, sohu.com, netease.com, tom.com, etc. will be allowed to show video clips under the new regulations (Beijing News 2006).

The move is part of a wider campaign by Chinese authorities to control Internet content. According to the 'Management Methods on Audio and Video Broadcasting over Information Networks Including the Internet', or SARFT Document [2004] no. 39, operators must receive a network audio and video-broadcasting license before they may send programming over the Internet. In particular, it stipulates that

Article 7: Exclusively foreign-owned enterprises, Sino-foreign joint ventures, or Sino-foreign contractual joint ventures may not engage in the operations of broadcasts of audio-visual programs through information networks. 
Article 20: Agencies with a permit shall establish a management system to complement the examination and safe broadcasting of programs, implement a chief program editor responsibility system, and equip staff program examiners to examine the contents of the programs being broadcast.

Article 2r: Operators of information networks may not provide services related to broadcasts of audio-visual programs to agencies that do not hold a permit to broadcast audio-visual programs through information networks.

Article 23: When relaying audio-visual programs through information networks, only radio and TV programs on the radio and TV stations may be relayed. No illegal programs can be relayed, nor can any overseas programs be relayed.

Even though the Measures did not specifically address Internet spoofing, it does mention that audio-visual programs refer to programs with an audio/video frequency that is composed of continuous images and continuously audible sounds, shot and recorded by a motion-picture camera, video camera, sound recorder, and other audio-visual frequency equipment for producing programs. The violators of the Measures may face a fine of up to RMB30, oo (US\$ 3,750).

\section{Censorship, profitability and responsibility}

Despite the Chinese government's determination to tighten its control over the Internet, the new medium poses challenges to such censorship because of its unique features. Ang and Nadarajan (I997) contend that freedom and openness are imbedded within Internet culture, which makes the Internet different from earlier media platforms. First, the distribution and gathering of information over the Internet grows at an exponential rate. It is a formidable task for the government to censor the content on the web considering the sheer breadth of information. Second, there are problems of law enforcement. Certain restricted materials may originate from overseas websites and it is difficult to penalize such breaches since one country's legislation does not apply to another. Therefore, sources of content may be remote from the jurisdiction of the country and there are fierce debates in the international arena in terms of what should be allowed to be published on the Internet and what should not. Third, government regulations can hardly catch up with the rapid development of the convergent technology, let alone control it effectively (Ang and Nadarajan I997). 
Therefore, the pre-existing policies and measures of the Chinese government that have proved to work effectively to regulate print and broadcast media may not apply to the Internet. China's media has long been structured as an integral part of the communist political system (Chang I989). It functions as an extension of political control of the Chinese Communist Party (CCP). The party principles, which determine all issues in media work, assure the CCP's domination over the media (Yan 2000). News media must take the party's guiding ideology as their own and must propagate the party's programs, policies and directives. The media must also be subordinate to the party's leadership and stick to the party's organizational principles and press policies (Zhao I998).

Before the economic reforms in 1978 , both the print and broadcast sectors operated under the 'party-organ model', where the party-state was the proprietor, the regulator, financier, and practitioner of the media. With the adoption of an 'open door' policy and market economy, the role of the media has changed dramatically owing to the liberalized economic environment and an increasing diversity of information sources for the general public. Under the 'market-based party organ model', media not only served as an ideological party mouthpiece and government cheerleader, but also as an instrument of economic development and social modernization (Pan and Chan 2000; Kalathil 2002).

The new system of 'socialist market economy with Chinese characteristics' has created 'a phenomenon of "duality" in the media scenario' (Wei 2000: 335). The media needs to strive for a balance between a party mouthpiece and a profitable business. In response to the country's state of stability, the press policy has undergone great volatility in the last two decades. On one hand, the party wants to continue exercising strict ideological control and supervision over the news media to ensure the public's support and social stability. This explains why the reporting style remains to be rigid and prudent as long as political content is concerned. On the other hand, the government seems to be more lenient and tolerant towards entertainment programs and publications (Yan 2000).

The licensing of news websites and the ban on news gathering and reporting by non-news websites clearly indicate the government's determination to ensure new media such as the Internet should function as extensions of the existing system of news media, whose operation and management is kept in line with the party policies. However, the intense conflict between the commercial news portals and the print media seems to be a direct result of Internet regulations. In order to maintain consistency and congruence and exclude 'deviance' from public discourse, the interests of the print media are sacrificed at the expense 
of offering the news they have gathered to non-news Internet portals almost for free. Deprived of the right to gather news, commercial websites have to use published content copied from the print media.

However, whether the print media and commercial portals would like to play by the rules and for how long remains questionable. Kalathil (2002) argued that the acceptable reportage boundaries have been pushed farther by small news websites, which make national organizations follow suit. The public often log in to find exclusive stories and the most up-to-date news, which can hardly be expected from traditional media.

Negative news stories are frequently disclosed on the web portals first, and then the government and state media are compelled to make quick responses. Moreover, the far-reaching effect of cellular phones and the multi-facet communication they provide such as Short Message Service (SMS) has also made the traditional control of information more difficult.

For instance, during the severe acute respiratory syndrome (SARS) outbreak in 2003, the government-controlled media organizations could only tamely follow the orders issued by the government, but the proliferation of the Internet and other new high-tech information sources provided the public with new channels of communication. The leaking of information via the Internet and great social anxiety caused by rampant rumors forced the central government to readjust its strategy in handling the SARS crisis (Zhao 2003).

With a host of Internet-related issues on the agenda, Chinese policymakers are being reactive rather than proactive because the architecture of the Internet makes censorship difficult at its core. Seeking to turn service providers into policemen and forcing ISPs to filter undesirable content and refuse access to undesirable users may prove to be fruitless and futile. Hu Ge's case indicates that a new content or application provider can emerge from nowhere to become an extraordinary success with a relatively low investment and without having to obtain a government license to offer new services. Despite the regulatory efforts directed at curbing online satire, individual users still have ways of bypassing censorship and letting their voices be heard in cyber communities. Pranksters may not choose to broadcast their films on the Internet. Instead, they could send them peer-to-peer or through Internetbased instant messaging networks, such as MSN.

The two Internet-related issues covered in this chapter reflect the social and economic tensions resulting from the conflicts between the free and decentralized architecture of the Internet and the relentless efforts of the Chinese government to assert controls over the technology as well as the content carried over it. On the one hand, the government endeavors to foster an enabling environment for the development of a 
more open market economy. On the other hand, it is tightening controls over news media and freedom of speech.

With the Internet reaching 16 per cent of the world's largest population, new technology will greatly facilitate information exchange and knowledge sharing among Chinese people. As the Internet emerges as a critical national infrastructure for the economy and society, the government has legitimate interests in having a degree of control over Internet activities and content. Striking the right balance between control and flexibility seems imperative as the Internet itself is undergoing constant transformations.

In summary, many perceived problems of the Internet should not be taken as defects to be fixed but instead as characteristics of the network. Most important of all, the value of openness should be upheld rather than downplayed if the government determines to serve a useful and better function, because openness fuels the innovation of technology as well as economic and political freedom.

\section{Notes}

I China Internet Network Information Center (CNNIC) defines Internet users as Chinese citizens aged 6 and above who have ever used the Internet over the last six months.

2 The China Daily is a state-run publication with the widest print circulation $(200,000$ per issue) of any English-language newspaper in China.

\section{References}

Ang, Peng Hua and Nadarajan, Berlinda (1997), Censorship and Internet: A Singapore Perspective. http://normative.zusammenhaenge.at/beitraege/sg-censorship.html.

$\mathrm{Bi}$, Zijia (2006), China Internet Content Control in the New Era (xin shidai beijing xia de zhongguo hulianwang neirong guanli). http://media.people.com.cn/GB/40628/5099164. html.

Chang, Won Ho (1989), Mass Media in China: The History and the Future. Ames: Iowa State University Press.

China Internet Network Information Centre (1997), Statistical Report on the Development of Chinese Internet. http://www.cnnic.net.cn/develst/97io/e-97io.shtml.

- (2008), The $21^{\text {st }}$ Statistical Survey Report on the Internet Development in China. http://www. cnnic.cn/uploadfiles/pdf/2008/I/I7/I04I56.pdf.

Congressional Executive Commission on China (2006), International Agreements and Domestic Legislation Affecting Freedom of Expression. http://10ooooobucks.info/index.php? q=aHRocDovL3d3dy5jZWNjLmdvdigwYWdlcy92aXJodWFsQWNhZC9leHAvZXhwbGF3cy5waHA\%2FUEhQUoVTUolEPWQzNzQ2M2QıMDBhZjIIMmMyYmRkZjNlMWExZTdkOGI4 $I_{25} \mathrm{ld}_{3} \mathrm{Nwb}_{3} \mathrm{NoaW}_{5} \mathrm{nbGF}_{3}$ \#newspostinglaw.

Evolution of Internet in China (2003), http://www.cnnic.net.cn/evolution.shtml.

Huang, Qing (2006), 'Parody Can Help People Ease Work Pressure'. China Daily 22 July: A4. 
Kalathil, Shanthi (2002), China's Media and the Information Revolution. http://www.ceip.org/ files/publications/kalathil_harvardasia.asp.

Liu, Jianhui (2006), The Winter of Newspapers: The Angry Chinese Print Media. http://www.zonaeuropa.com/20060522_3.htm.

Pan, Zhongdang and Chan, Joseph Man (2000), 'Building a Market-based Party Organ: Television and National Integration in China', in David French and Michael Richards (eds.), Television in Contemporary Asia, 233-263. New Delhi: Sage Publications.

Review of China's Internet Regulations and Domestic Regulation, http://www.ichrdd.ca/english/ commdoc/publications/globalization/legislationInternetChinaEng.pdf.

The Beijing News (2006, August 15), 'Internet Video Clips to be Regulated' (Wangluo duanpian jiangyou xingui jianguan). http://news.thebeijingnews.com/0565/2006/08-I5/ OI5@031742.htm.

Wei, Ran (2003), 'China's Television in the Era of Marketisation', in David French and Michael Richards (eds.), Television in Contemporary Asia, 325-346. New Delhi: Sage Publications.

Wu, Zhong (2006), 'Chinese Newspapers Mull Internet Boycott'. http://www.zonaeuropa. $\mathrm{com} / 20060522$-3.htm.

Xinhua News Agency (2006, August I6), 'New Regulations to Control Online Videos'. http://www.china.org.cn/english/GS-e/r78II2.htm

Yan, Li (2000), 'China', in S.A. Gunaratne (ed.), Handbook of the Media in Asia, 497-527. New Delhi: Sage Publications.

Zhao, Jinqiu (2003), 'The SARS Epidemic Under China's Media Policy'. Media Asia 30(4): I9I-I96.

Zhao, Yuezhi (1998), Media, Market and Democracy in China: Between the Party Line and the Bottom Line. Urbana and Chicago: University of Illinois Press. 



\section{List of Contributors}

\section{Friederike Assandri}

Research Associate

Department of Sinology, University of Heidelberg, Germany

Center for the Study of Chinese Characters, ECNU, Shanghai, China

\section{Paul Bailey}

Professor of Modern Chinese History

School of History, Classics and Archeology, University of Edinburgh, Scotland, UK

\section{Tsu-yu Chen}

Research Fellow

Institute of Modern History, Academia Sinica, Taipei, Taiwan

\section{Joseph Tse-Hei Lee}

Professor

Department of History, Pace University, New York, US

\section{Dora Martins}

Coordinator of the Centre of Politics and International Relations

Portuguese Institute of Sinology, Lisbon, Portugal

\section{Yuki Ooi}

Research Fellow

Japan Society for the Promotion of Science, Tokyo, Japan

\section{Wensheng Wang}

Assistant Professor

Department of History, University of Hawai'i at Manoa, US

\section{Jinqiu Zhao}

Associate Professor

Communication University of China, Beijing, China 



\section{Index}

Africa I2, 62, II3

America 53, 56, 58, 60, 62-64, I27

Americanization 63

Anglo-Chinese College 74, 8I-82

Anti-Christian Movement 69, 7980,82

Ashmore, William 7I

Aulard, Alphonse II5-II6, II9

Austria 54

Bai Ling 4I

Baptist mission 69-73, 76, 79-80

barbarian 57, 64, II7

Boxer Uprising $49,54,73,84$, II2

Britain 54, III, II3, II5

Buddhism 9, I5-I7, I9, 22, 24-29, 34, 37

Buyandalai 43

Cai Yuanpei II4, II6

capital appeals Io, 33, 39-44, 46, 49

censorship I3, I42, I46-I47, I49

Chang Wen 43

Chaozhou II, 67-72, 74-79, 83-84

Chen Fuqian 96, 107

Chen Jiongming $\quad 75-78,80-82$

Chen Kaige I45

Chen Luo 93

Chen Yuting 74, 82

Chen Zhonghe 96-97

Cheng Xuanying 24, 26

Chinese American 59

Chinese Americans Io, 60-6I

Chinese consciousness 55, 60, 69, 83

Chinese Exclusion Law $57-58$

Chinese immigrants $55,57-59,63-$ 64 , II8

Chinese workers III-II4, II6-II8, I2O
Christianity II, 63, 67, 69-72, 74, 80,84

church-state relations II, 67-68

civilisation 62

civilization 56-57, 6I-64

Cohen, Paul A. 7I

colonial authorities 89-92, 96-97,

99, IOI, IO4

comprehensive security I3, I34-I35,

I37

Confucianism $35,38,54,63,136$

Confucius 35, II5-II6, II9, I27

Confucius Institutes I35

contact zone Io, 53, 57, 6I-64

conversion debate (huahu) 27

coolie trade II2-II3

cooperative security I3, I34, I37

copyright $\mathrm{I} 3, \mathrm{I} 42, \mathrm{I} 45$

crises Io, 33, 43-46, 48, 76, 84

Daoism 9, I5-I7, I9, 22, 25-30, 37

Daoxuan Io, I5-I9, 22-26, 28-30

Deng Xiaoping I2I, I24, I34

development 9-II, I3, I6, 29, 44, 47-48, 62, I04-I05, I2I, I23-I27, I34-I35, I48

Ding Keyu 43

du Rosaire, Sister Marie 78

Dubail, Georges II5

Ducrocq, Georges II5-II6

economic diplomacy I3, I34, I37

Empress Dowager 54

France 9, I2, 54, III-II6, II8-I20

freedom of speech I3, I42, I5O

Fu Yi 29

Gaozong, Tang emperor I7-I8, 23

Gaozu

- Emperor of the Qi dynasty I9

- First Tang emperor 29 
Gee Woo Chan 59

Germany 54, III-II3, I32

Gotō Shimpei 90-91, 93, I06

Gu Xianrong 90-91, 93-97, I06

Heriot, Edouard II5

Heshen 45, 49

Hildreth, Ellison 76

Hong Liangji 44

Hong Sing 59

$\mathrm{Hu} \mathrm{Ge}$ I45, I49

Hu Jintao I26

Huang Yupian 38

Huili 26

Huiming 43

identity Io, 60-6I, 72

- Chinese identity 53, 55, 6I, 69

- Chinese-American identity 6I

- clan identity 6I

- ethnic identity 53, 6I

- national identity 53-55, 6I

Indian

- Indian eristics $19-20,22,25$

- Indian logic 20, 26, 29

intellectual property rights I45

inter-religious court debate 9, I5-I6, I8

Italy 54

James, T.W. Douglas 76

Japan II, 54-55, 89-9I, 93, 96-99,

IOI, IO4-IO7, II2-II3, I23, I3I-I32,

I34

Japanese government 89-90, 97IOI, I04-106

Japanese salt 97-99, IOI, IO4-IO5

Jia Yunsheng 40

Jian Langshan 96

Jiang Jieshi 82,84

Jiang Zemin I25, I27, I34

Jiaqing emperor Io, 33-34, 37, 39, $4 \mathrm{I}-44,48$

Jiaqing reform $33,46,48$

Jijiaye 20

Jishan 4I

Kissinger, Henry $\quad$ I32
Korea 55, IOI

Kotama Gentarō 90-9I, IO4

Kuang Yuanli 43

Kurihara Tomijiro 98

Laozi 26-27, I28

Li Bingjun 93

Li Hongzhang 73

Li Rong I8, 29

Li Shizeng II4-II6

Liang Wudi 23

Lin Mugen 96

Lingbian 26

Liu Renlong 43

Liu Tingyu 93

logic 20-2I, 25-26

Lu Chengxiang II8

Lu Yan 43

Mao Zedong II2, I26

mediation 69, 84, II5

modernisation I0, $53,62,84$

modernization 9-I3, 53, 55-56, 63$64,67,74,83,148$

Moutet, Marius II5

Mozi I28

new security concept I2I, I24-I25

news posting I43

Nishita Akari 104

North Korea I35

Nyāya sutras 20

online satire I3, I42, I45

Orientalism 62

Painlevé, Paul II5, II8

Pan Dongzi ${ }_{146}$

Pang Dachun 43

Paramārtha 20, 30

Paris Peace Conference I2

peace II3, II9-I20, I24, I28, I30,

I32, 136

peaceful development I2I, I27

peaceful rise I2I, I24, I26-I27, I32

Peng Pai 82

Peng Songshou 96

Poincaré, Raymond II8

political retreat Io, 34, 46, 48 
Presbyterian mission $\quad$ 70-74, 76-83

Prince of Jingling 23

pure talk, qingtan I5, 25, 30

Putnam, F.W. 57

Qi Shirong I25

Qian Chengdan I25

Qianlong

- Emperor of Qing dynasty Io

- Emperor of Qing dynasty 33, 3538, 42, 44-50

Qin Shihuangdi I29

Ren Siyue 43

Ross, Malcolm 76

Roudière, Fr. 76

Russia 54, 97

salt monopoly II, 89-93, 96, 99, IOI, IO4

semi-colony II2, II8

Shandong $36,42,49,72$, IOI, IIIII3

Shantou 70, 72-76, 78-84

Siam 69

soft power I3, I34-I35, I37

South China piracy $33,39,42,46$, 48

spoof I45-I47

state-building 9-10, I3, 67-69, 83-84

Sun Yat Sen $63,75,77-78$

Sunzi $\quad$ I28

sustainable development Io, 46, 50, I25

sustainable socio-political development $33,46-48$

table salt $89,95,98$, IOI, IO4-IO5

Taiping rebellion 33,54

Taiwan 9, II, 50, 89-93, 97-99, IOI, I04-I07, I24, I27, I30-I3I, I35

Taiwan Salt Production Company (TSPC) 94-95, 98, 106

Taiwanese Governor-general 90

Taiwanese salt I2, 89-92, 98-99, IOI, I04-IO6

Taizong, Tang emperor I9

Tanyao 20
Tanzania II9

Tiantai Zhiyi 24

tribute gifts Io, 33, 44-46

Twofold Mystery, chongxuan 26, 28

United States II, 53-57, 59-60, 62-

64, II8, I24, I3I, I4I

Versailles Peace Conference III, II8

Versailles Peace Treaty II 8

Wallace, H.F. 8I

Wang Ji 42

Wang Qingzhong 93

Wang Weiping 43

Wang Zhengzhi 43

Wang Zhiyin 4I

Wen Chenghui 4I

Wen Jiabao I26

White Lotus sect Io, 33-39, 46, 49

Wong Aloy 6I

Wong Chin Foo 59, 63

Wong Fee 59

Wong Kee 60

World War One 9, I2, III-II4, II6, II8

World's Columbian Exposition 56, 6o, 64

Wu Peifu 78

Wu Tianxiang 43

Wu Zhi 43

Wu Zhihui II4

Wu, Emperor of the Northern

Zhou 18

Xiao Rui 43

Xu Shichang II8

Xuanzang 20, 26

Yang Shangqiong 43

Yongle, Emperor of Ming

dynasty I29

Yongzheng, Emperor of Qing dynasty 45

Yu Ruiying 43

Yuan Shikai II3

zaibatsu I2, 97, I06

Zhang Jingjiang II4

Zhang Kao 4I 
Zhang Qian I29

Zhang Zuolin 78

Zheng Bijian I26
Zheng He I28-I29

Zhou Enlai 82

Zhu Shouhai 43 


\section{icas Publications Series}

\section{Monographs}

Marleen Dieleman

The Rhythm of Strategy. A Corporate Biography of the Salim Group

of Indonesia

Monographs I

2007 (ISBN 9789053560334 )

Sam Wong

Exploring 'Unseen' Social Capital in Community Participation. Everyday

Lives of Poor Mainland Chinese Migrants in Hong Kong

Monographs 2

2007 (ISBN 978905356034 I)

Diah Ariani Arimbi

Reading Contemporary Indonesian Muslim Women Writers.

Representation, Identity and Religion of Muslim Women in Indonesian

Fiction

Monographs 3

2009 (ISBN 9789089640895 )

Euis Nurlaelawati

Modernization Tradition and Identity. The Kompilasi Hukum Islam and Legal Practice in the Indonesian Religious Courts

Monographs 4

2009 (ISBN 978908964088 8)

\section{Edited Volumes}

Sebastian Bersick, Wim Stokhof and Paul van der Velde (eds.)

Multiregionalism and Multilateralism. Asian-European Relations in a

Global Context

Edited Volumes I

2006 (ISBN 978905356929 0) 
Khun Eng Kuah-Pearce (ed.)

Chinese Women and the Cyberspace

Edited Volumes 2

2008 (ISBN 978905356 75I 7)

Milan J. Titus and Paul P.M. Burgers (eds.)

Rural Livelihoods, Resources and Coping with Crisis in Indonesia.

A Comparative Study

Edited Volumes 3

2008 (ISBN 978908964055 )

Marianne Hulsbosch, Elizabeth Bedford and Martha Chaiklin (eds.)

Asian Material Culture

Edited Volumes 4

2009 (ISBN 978908964090 I)

Hans Hägerdal (ed.)

Responding to the West. Essays on Colonial Domination and Asian Agency

Edited Volumes 5

2009 (ISBN 9789089640932 )

Derek Heng and Syed Muhd Khairudin Aljunied (eds.)

Reframing Singapore. Memory - Identity - Trans-Regionalism

Edited Volumes 6

2009 (ISBN 9789089640949 ) 